Fall 1940

\title{
1940 Cedrus Yearbook
}

Cedarville College

Follow this and additional works at: https://digitalcommons.cedarville.edu/yearbooks

Part of the Higher Education Commons, Organizational Communication Commons, and the Public Relations and Advertising Commons

\section{Recommended Citation}

Cedarville College, "1940 Cedrus Yearbook" (1940). Yearbooks. 69.

https://digitalcommons.cedarville.edu/yearbooks/69

This Book is brought to you for free and open access by DigitalCommons@Cedarville, a service of the Centennial Library. It has been accepted for inclusion in Yearbooks by an authorized administrator of DigitalCommons@Cedarville. For more information, please contact digitalcommons@cedarville.edu. 


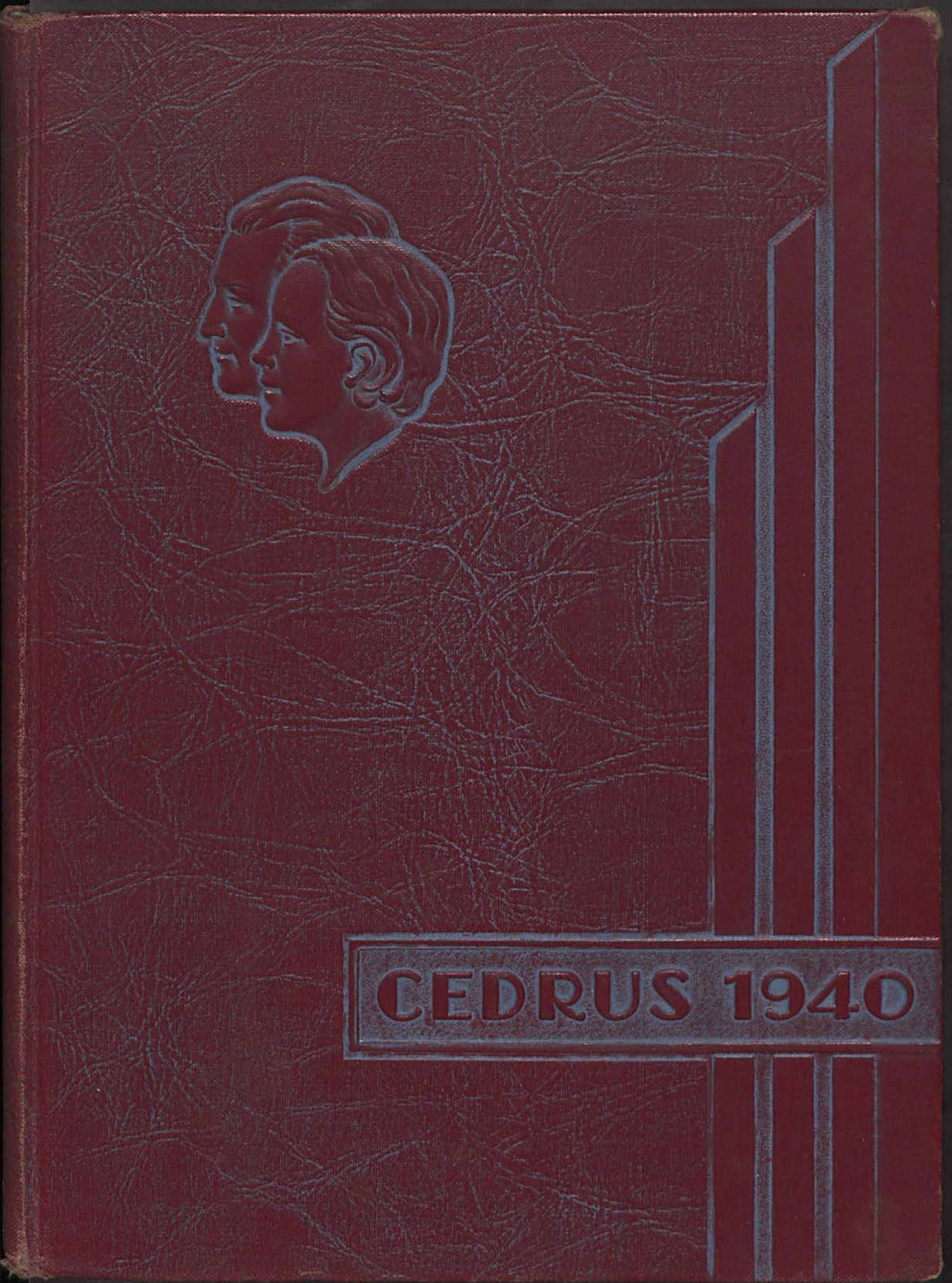




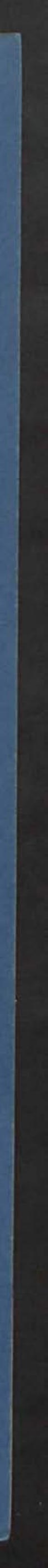




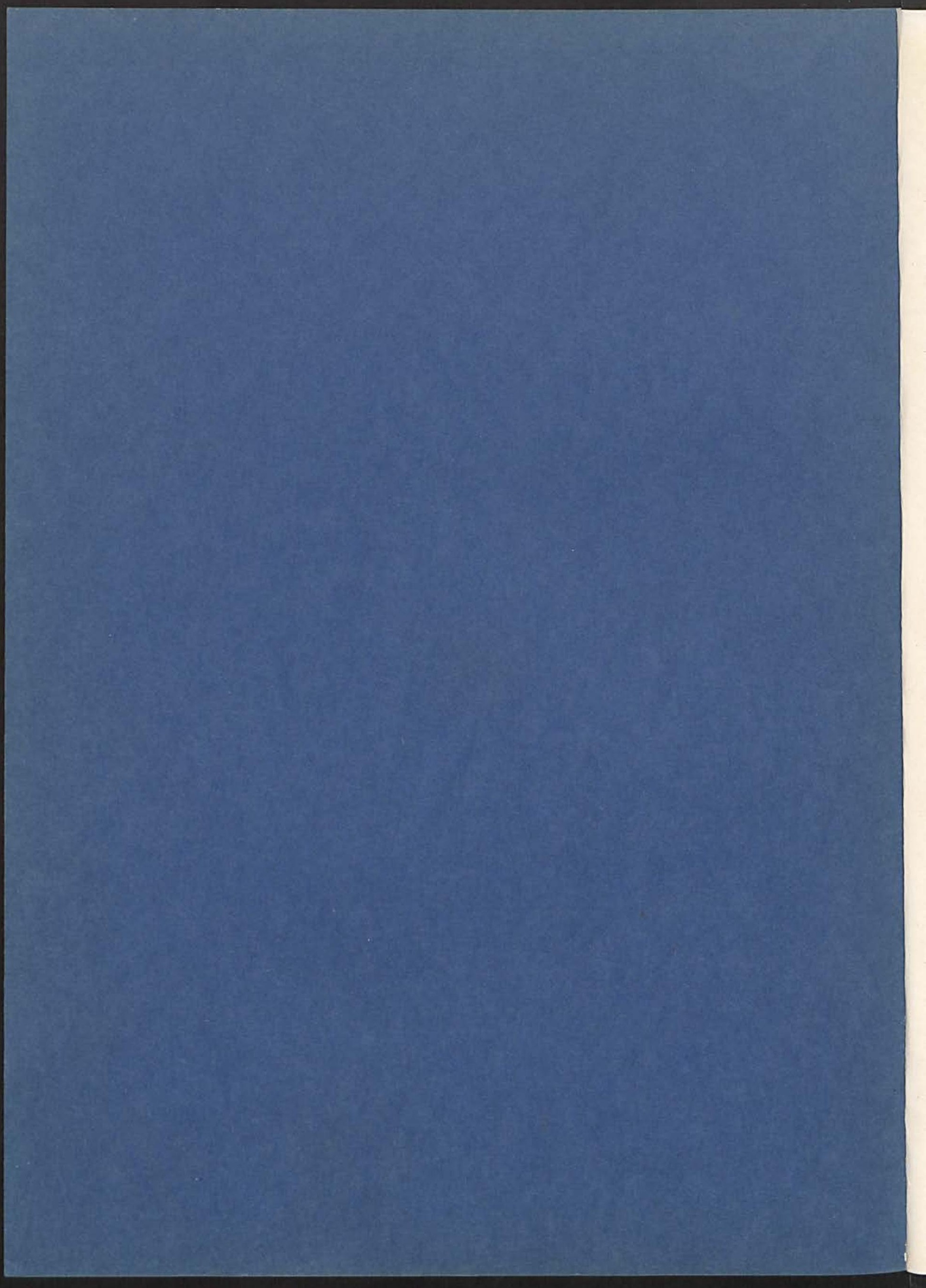






\section{THECEDUS}
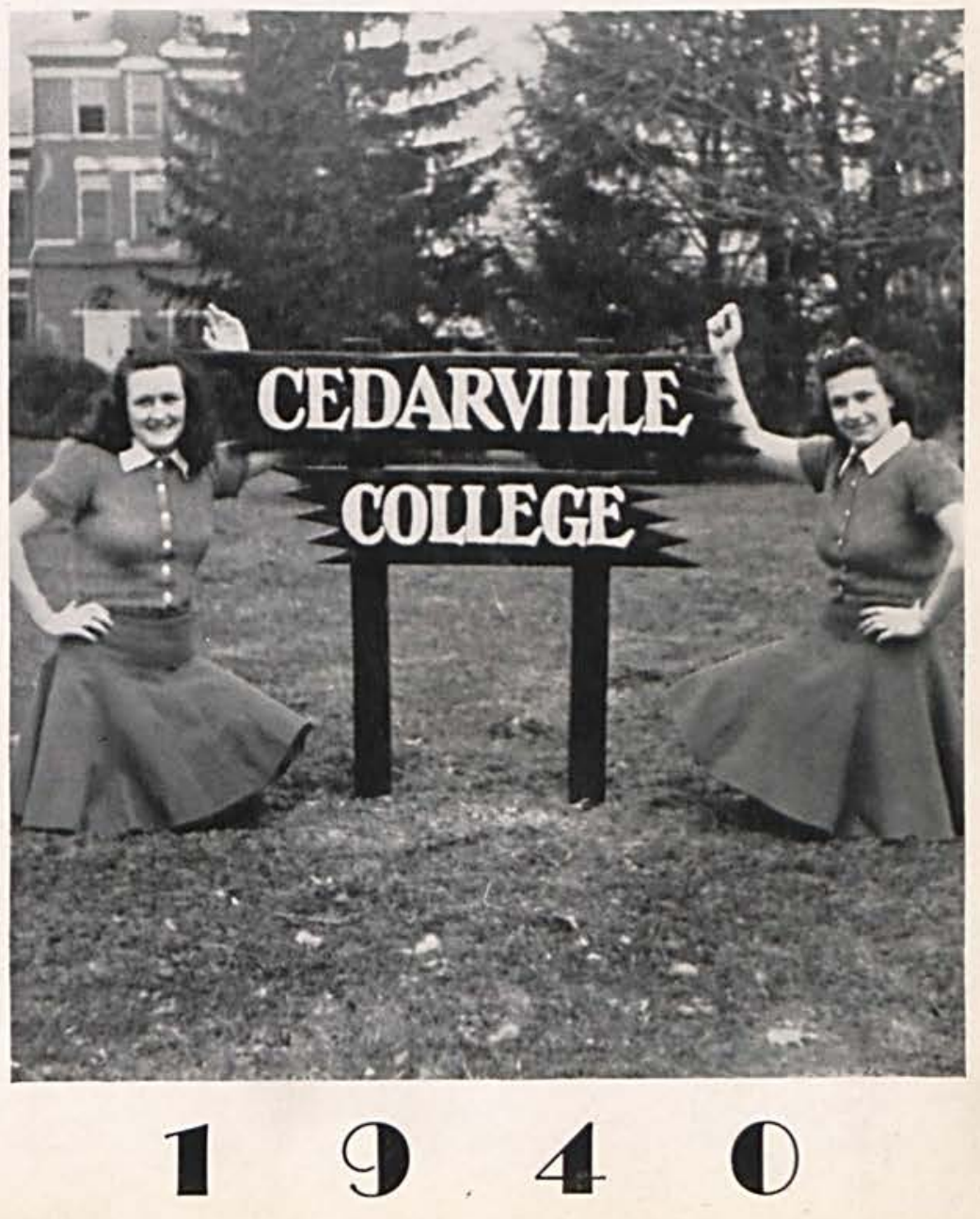

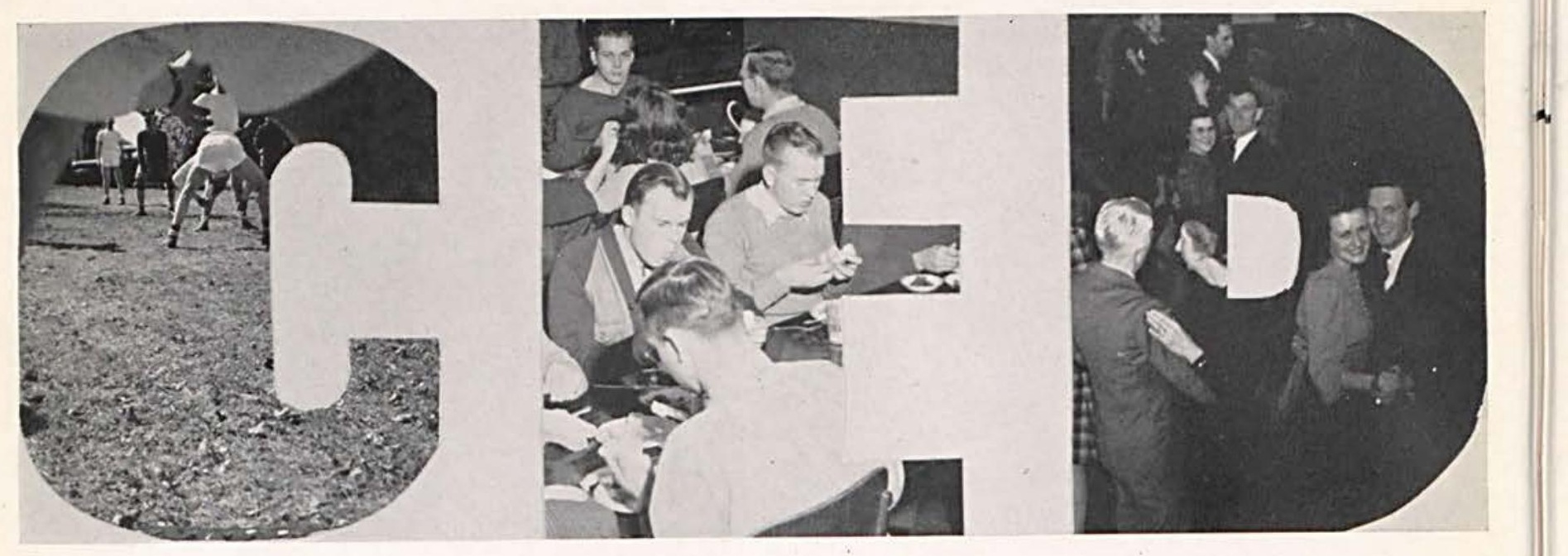

DRESENTING DICTURES OF 

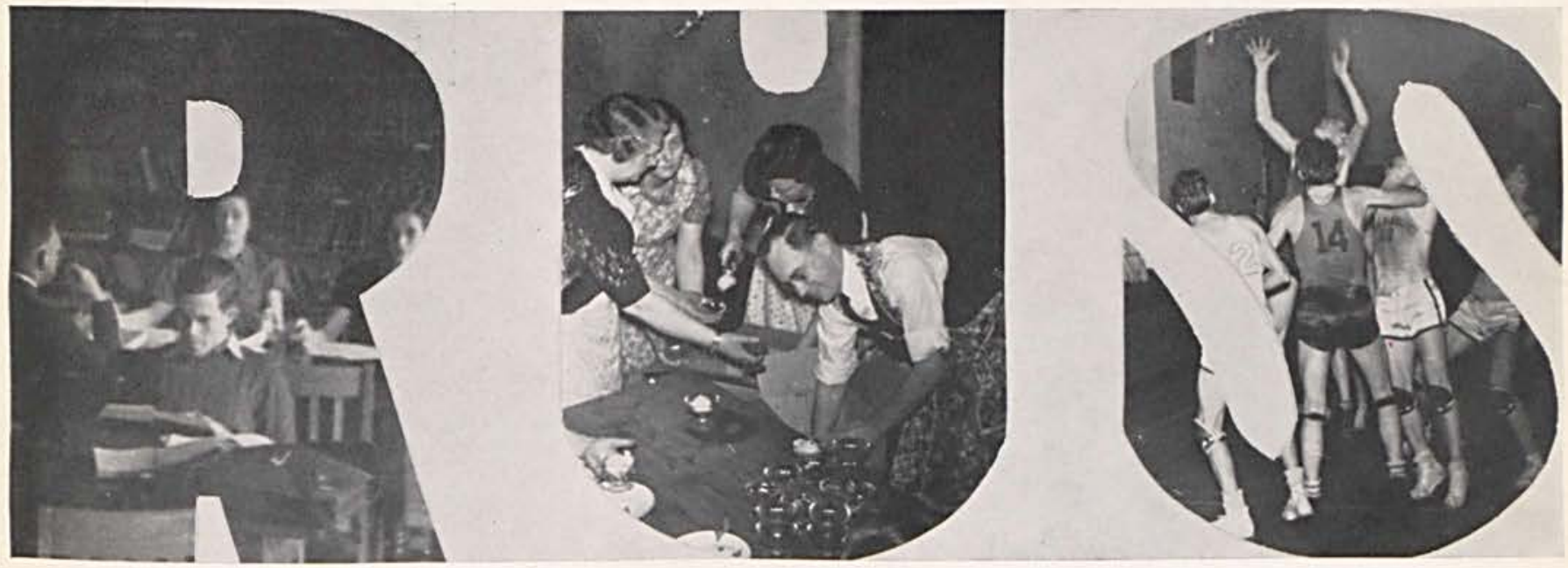

NINETEEN

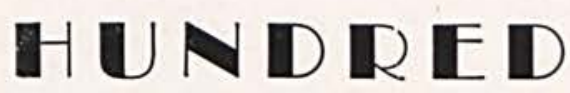

FORTY

COMPILED, EDITED AND

PUBLISHED ANNUALLY

BY THE CEDRUS STAFF

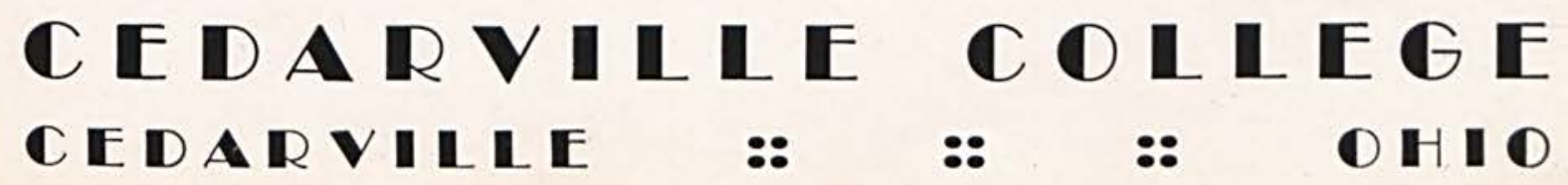




\section{TAKEN F}

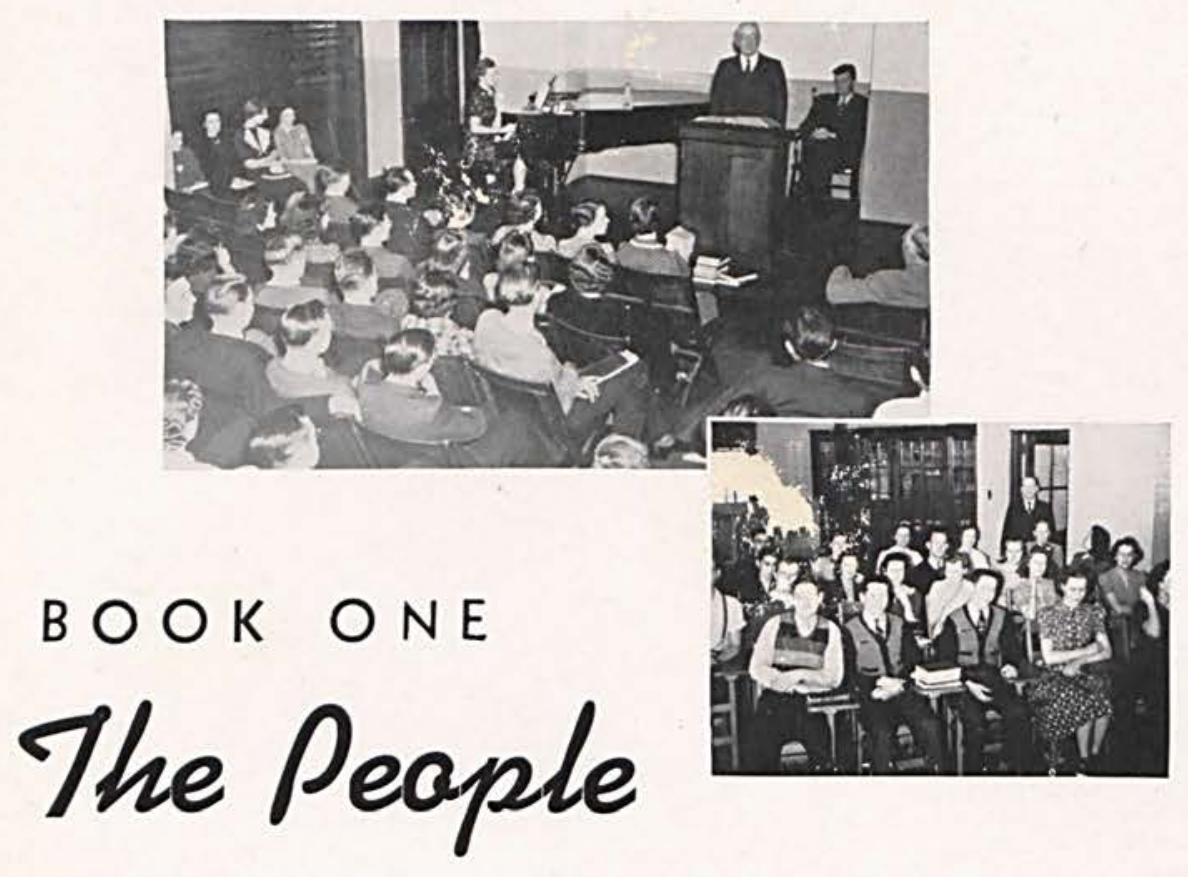

BOOK TH. EE

Their Activities 
OR REMEMBRANCE

OF 264 DAYS FILLED WITH HOURS OF

LIVING, LEARNING, STUDYING, WORKING PLAYING, CHEERING, LISTENING, WATCHING WAITING, AMONG THESE - . - OUR MEMORIES OF

BOOK TWO

Their Athletics 

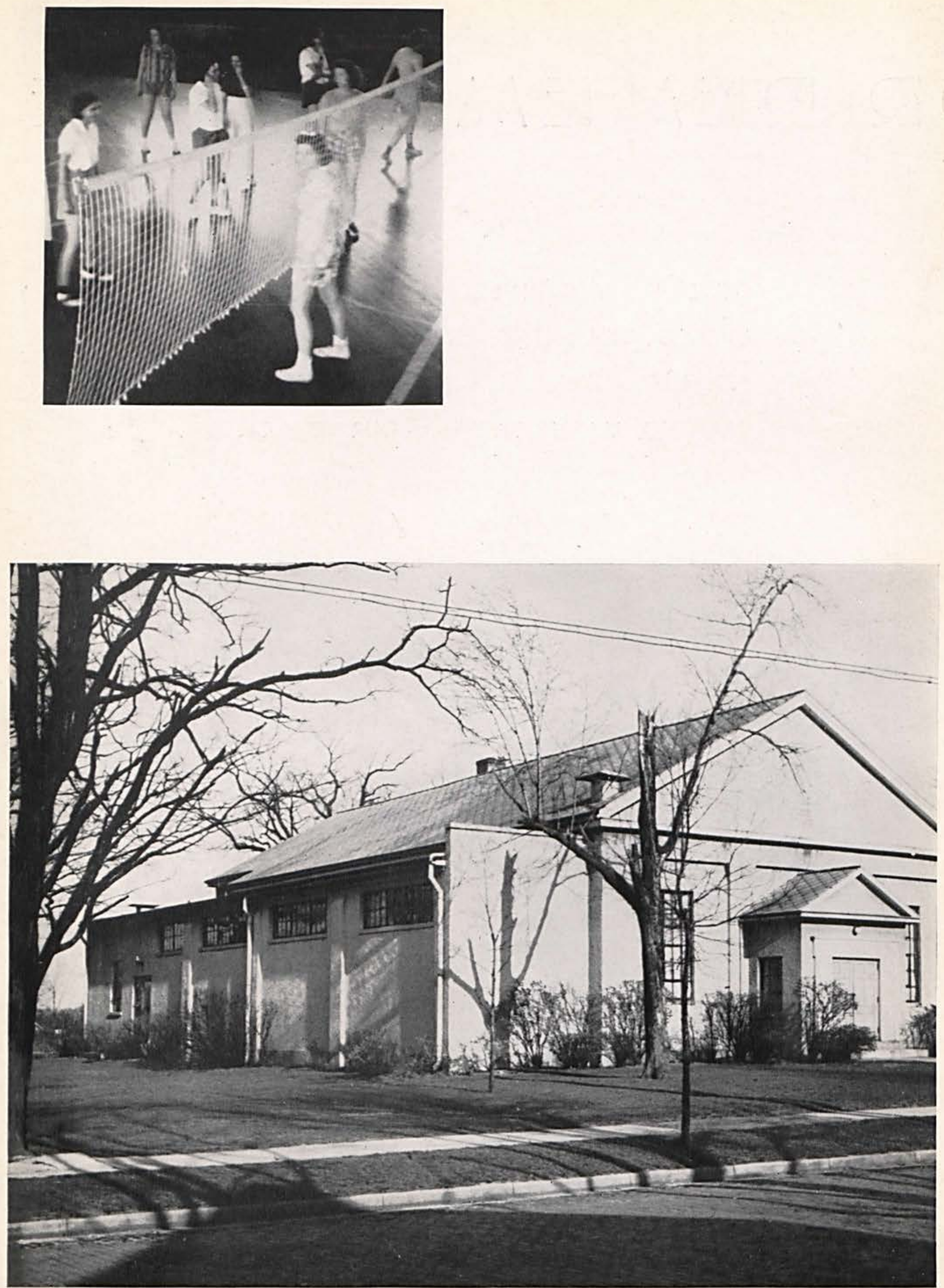

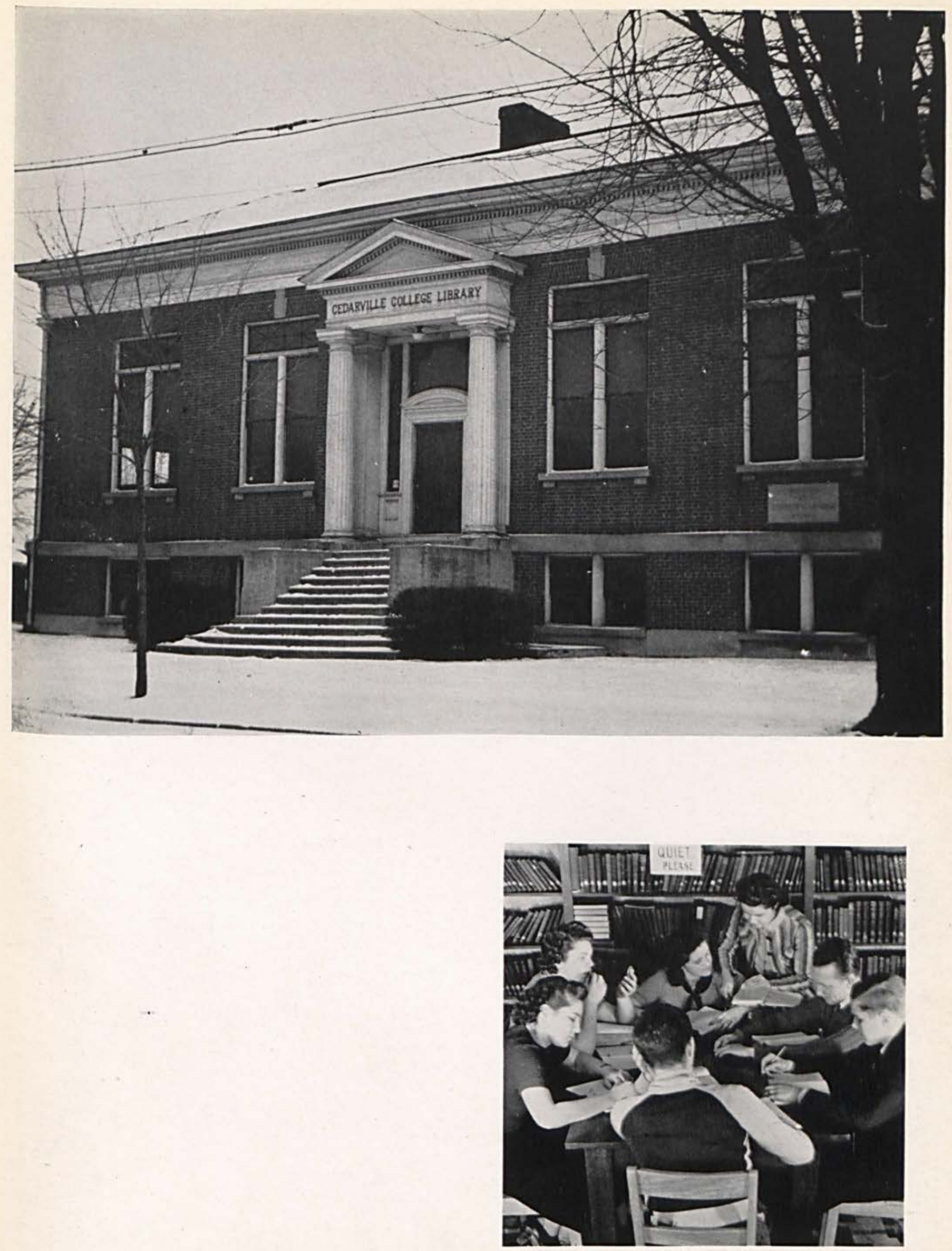

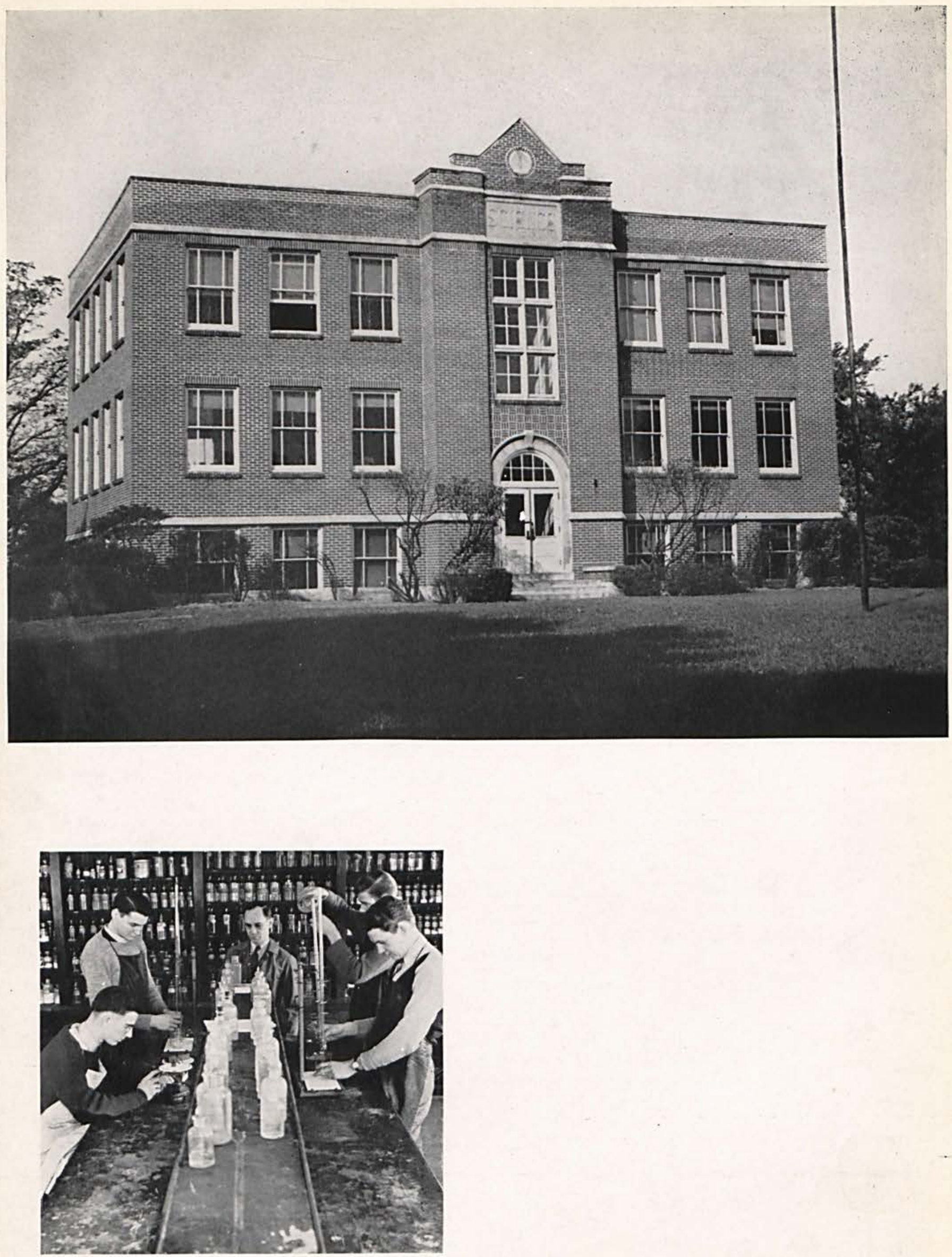

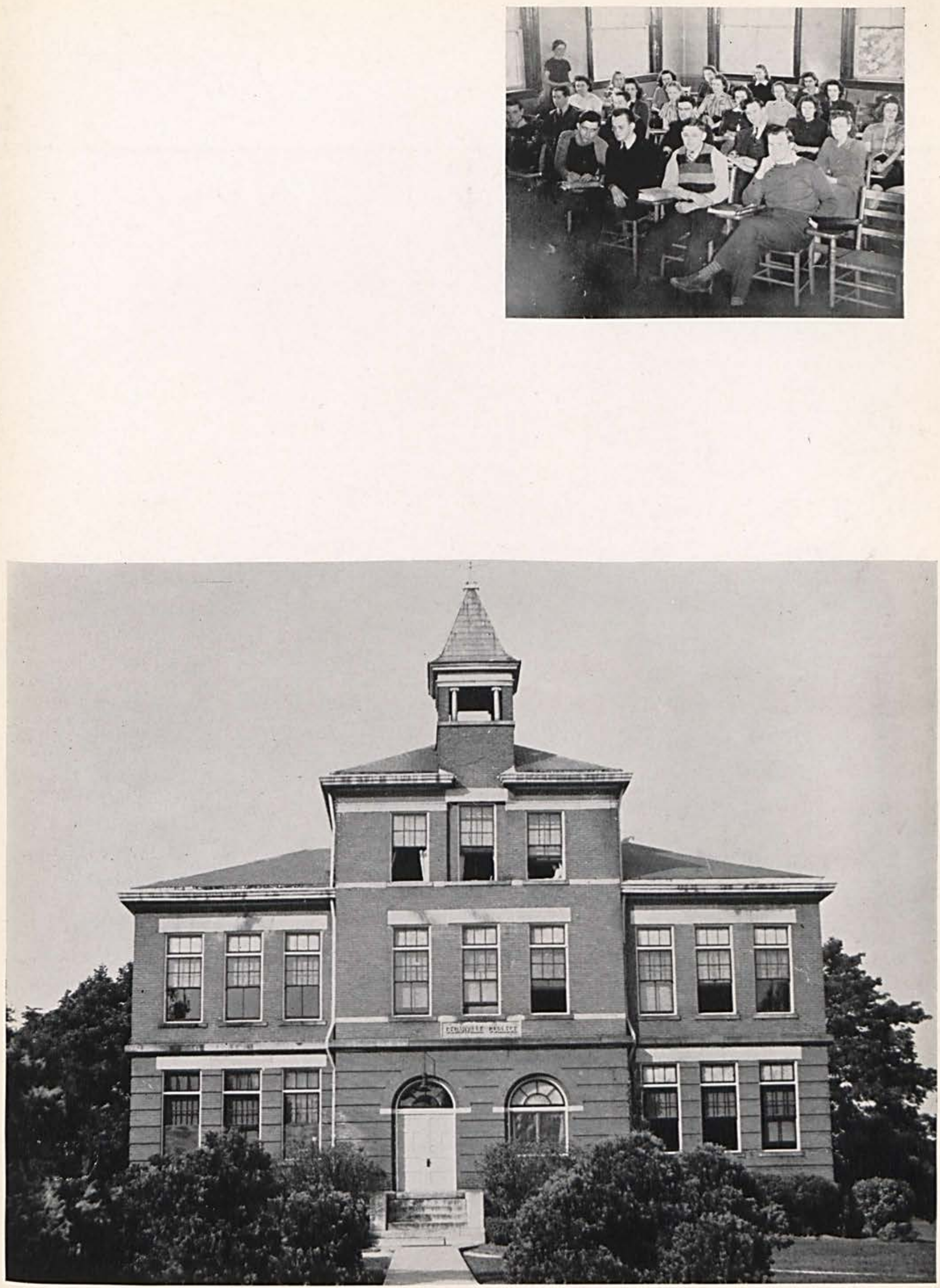
BOOKONE The Peaple.... noministen 


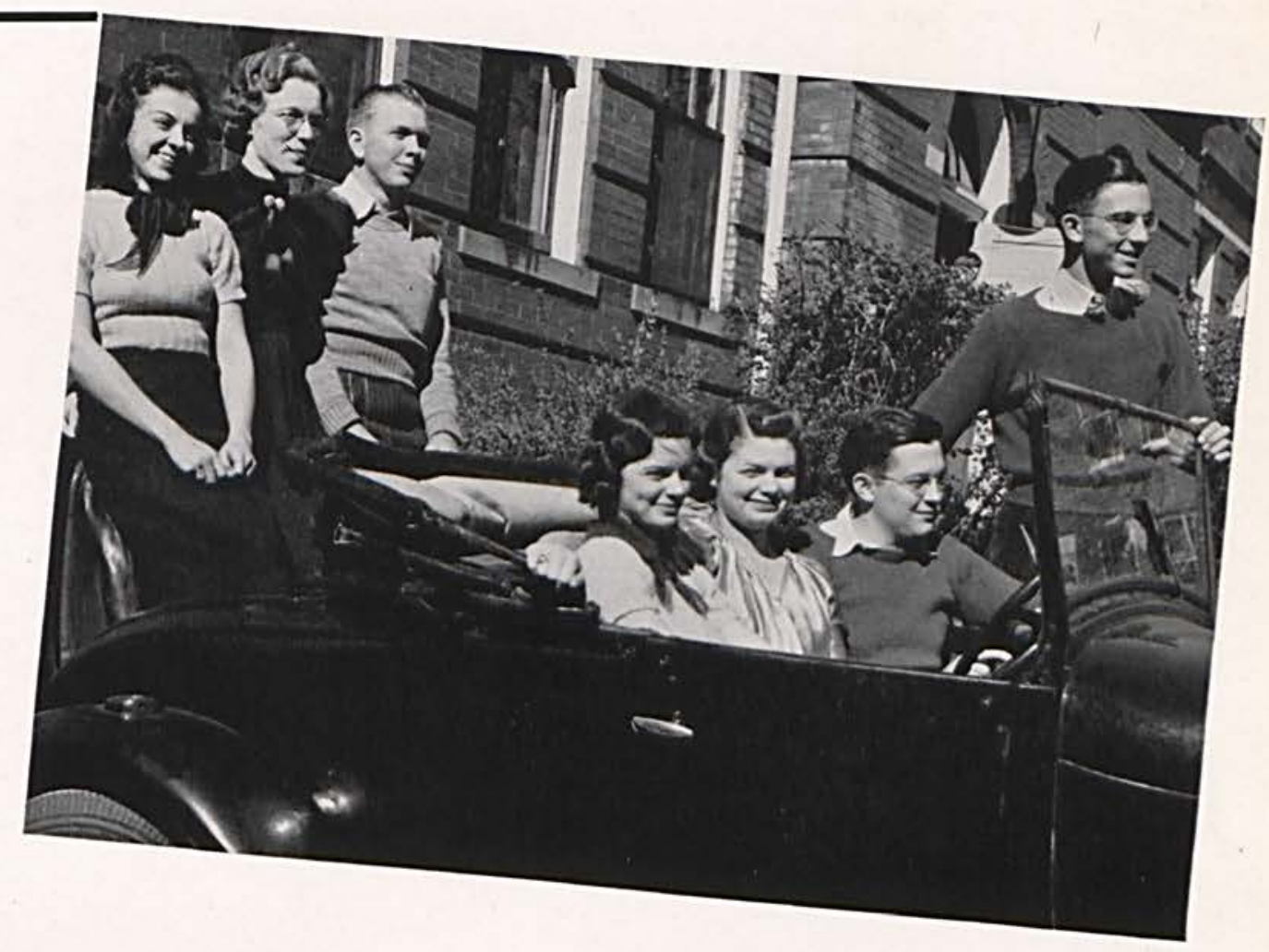

ATION. . FACULTY. . STUDENTS. . . 


\author{
BOARD OF TRUSTEES \\ CEDARVILLE COLLEGE \\ $1939-1940$
}

\title{
BOARD OF TRUSTEES
}

REV. W. C. HOWARD is the president of the Board and is a minister in Chicago, III.

W. C. ILIFF, vice-president, is a contractor in Cedarville.

WM. H. TILFORD, secretary is a minister in Cincinnati, $O$.

J. LLOYD CONFARR, treasurer, formerly connected with the Hagar Straw Board and Paper Co. in Cedarville.

S. FRANK CRESWELL, a graduate of the 1910 class is the owner of a local grain elevator:

DWIGHT R. GUTHRIE is the minister at Northminster Presbyterian Church in Springfield.

CARL SHANKS, class of 1927, is the County Superintendent of the Clinton County Schools at Wilmington.

GEORGE H. HARTMAN is a local clothier

JAMES L. CHESNUT, class of 1918 , is a minister at Fairmont, W. Va.

WM. R. GRAHAM, class of 1905, is in the ministry in Lafayette, Ind.

KARLH BULL is the editor of the Cedarville Herald.

WILLIAM R. COLLINS, class of 1918, is connected with the American Book Co. in Chicago.

R. W. Ustick, class of 1911, is a minister in Springfield, $O$.

LEO ANDERSON is a prominent veterinarian here in Cedarville.

S. C. Wright, class of 1903, is a former judge of Greene County and resides in Cedarville.

HARRY POUNSFORD is at the head of the Pounsford Stationery Co. in Cincinnati, $O$. WILLIAM CONLEY is a Member Emeritus, being retired and now living in Cedarville. 
Dear Friends of Cedarville

College:

On the tenth of July, 1940 , forty-six years will have come and gone since I came to Cedarville.

I have never regretted my coming, and, though frequently invited to more lucrative positions, I chose to remain with Cedarville College.

Now, I have chosen to retire from the administrative duties of Cedarville College, but to continue as a teacher.

I bespeak for the incoming president, Rev. Walter S. Kilpatrick, the loyalty and liberal support of all who believe in and love Cedarville College.

With gratitude to all who have stood by me and my work, I am

Sincerely yours,

W. R. McChesney, President.

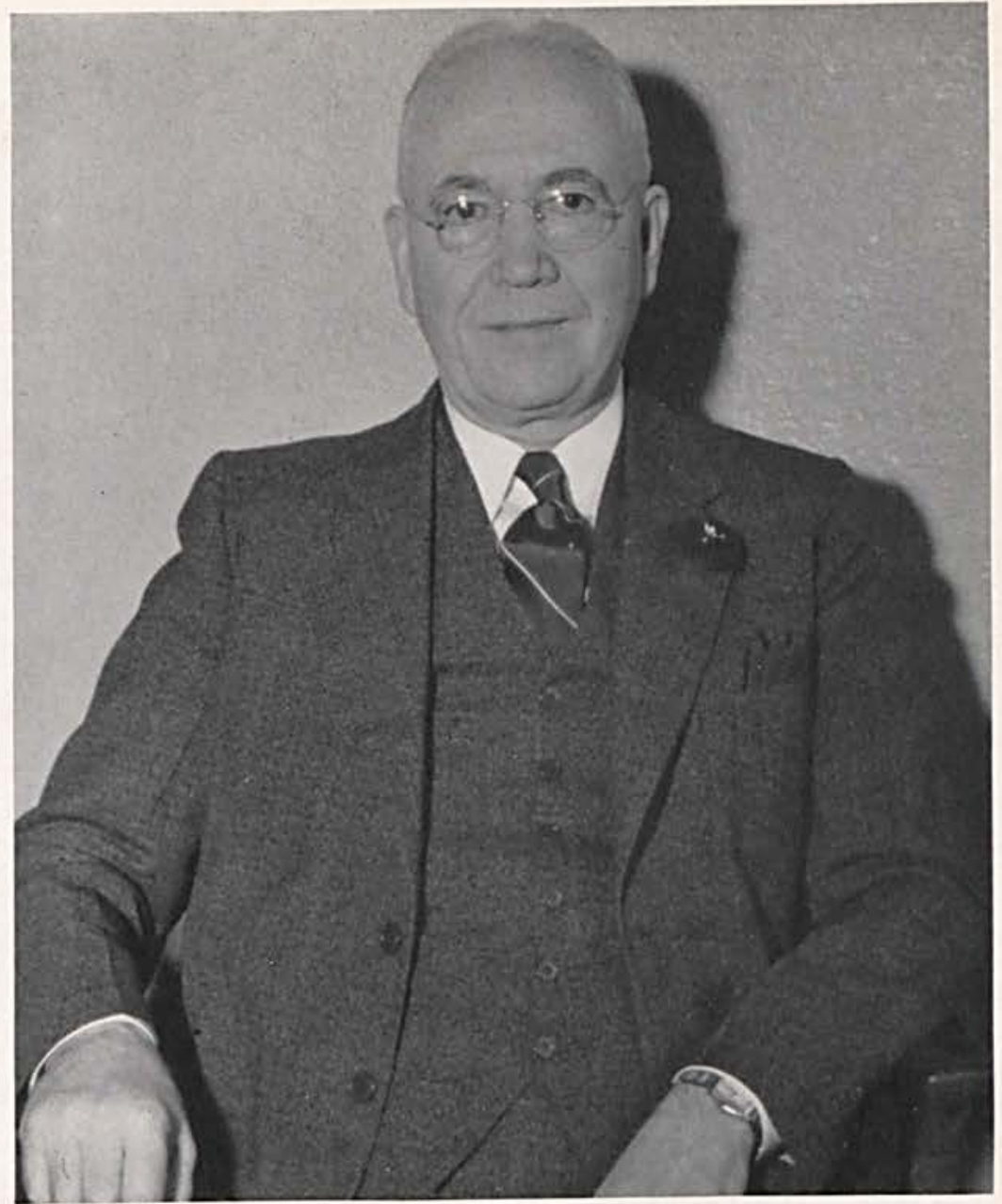

\section{OUR DEAN OF MEN}

(Not Illustrated)

Mr. C. W. Steele, Dean of Men, received his training at Indiana State Normal School, Indiana Teachers' College, and Northwestern University. $\mathrm{He}$ is very sincere and is doing a great work for the college.

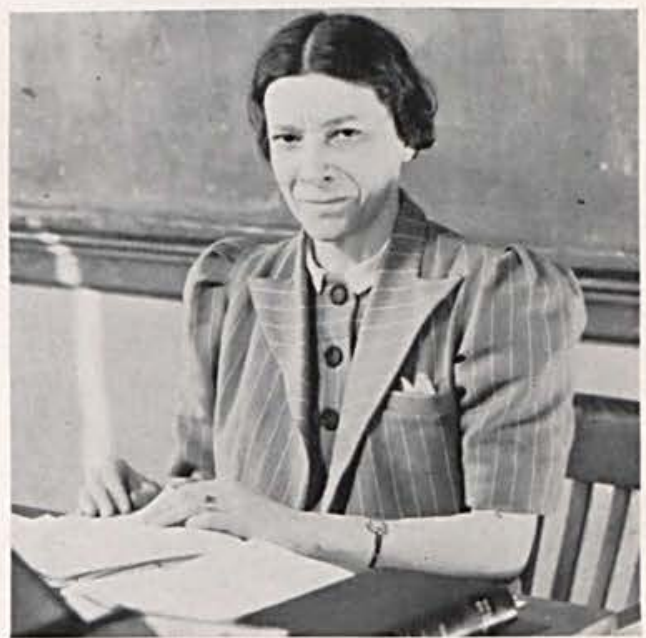

Miss Helen Santmyer, Dean of Women, is a graduate of Wellesley College, Mass., and received additional training at Oxford, England. She is the professor of both Latin and English. 


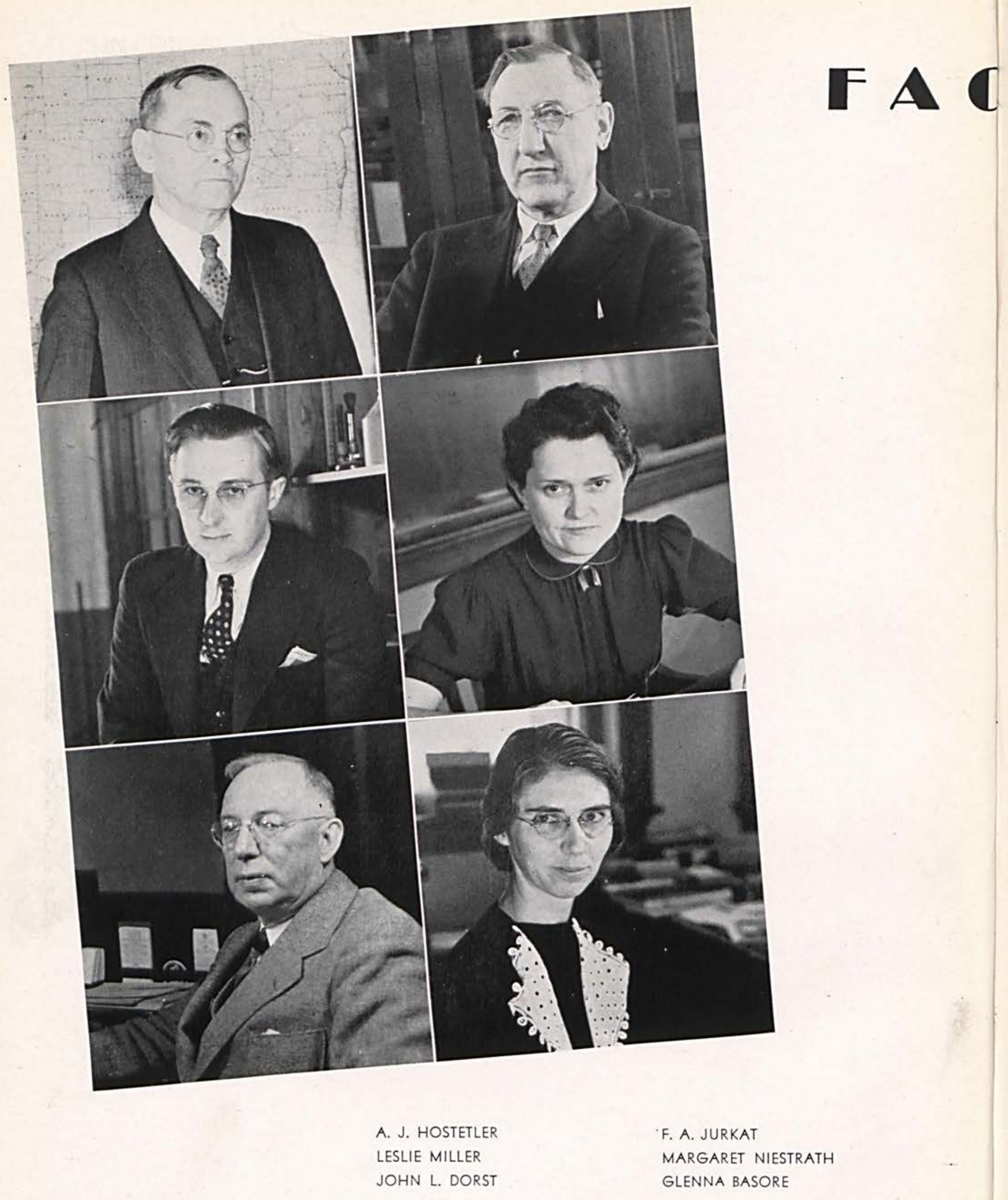


PROFESSOR A. J. HOSTETLER is the Registrar degree from Ohio Northern University and an A.M. at Wittenberg College. Mr. Hostetler is well-known in the educational field, having served in various phases of the teaching profession. His epartment has done exceptionally well in securas in the state of Ohio.

COACH MILLER produced a winning combination with the Yellow Jackets in basketball. The team has had an enviable record for these two years to say nothing of a Northwest Ohio Conference championship in 1939. He received his A.E. at Rio Grande College and A.M. at Ohio University.

$\mathrm{He}$ is to be commended upon his good nature and the hard work he has done these two years.

MR. J. L. DORST is the business manager of the college, and a most efficient one he is, too. He has had a great deal of experience in Y.M.C.A. work. This naturally gives him a good understanding of youth. $\mathrm{He}$ is pleasant and is always willing to help and does his best for the students and the college.
DR. F. A. JURKAT has been a member of the faculty for a good many years. He has an uncanny memory and can talk intelligently on almost any subject. He received his LL.D. at Franklin College and has done graduate work both at Wittenberg College and Ohio State University. $\mathrm{He}$ will be remembered by all students for his subtle humor, informal classes, and willingness to help all.

MISS MARGARET NIESTRATH is the new professor in French and Public Speaking. Miss Niestrath received a B.S. in Education at Miami University and her M.A. at Ohio State University. Before coming to Cedarville she taught in Ohio City High School, Williamsburg High School, and Grandview Heights High School. She is very active in college activities and is faculty advisor of the Chi Sigma Phi Sorority.

MISS GLENNA BASORE takes care of the secretarial duties of the college. She received a degree in Dramatics from Ohio Northern University, the A.B. degree from Cedarville College. Miss Basore acts as a Bureau of Information for the students and faculty. Miss Basore has an exceptionally sunny disposition and is well-liked by all. 
PROF. ERNEST R. GIBSON has been a member of the faculty for the past three years. $\mathrm{He}$ is the science teacher and faculty advisor of the Cedrus. He was a graduate of Cedarville College in 1928, and later received his graduate work at Ohio State University. Mr. Gibson is one of the most popular of faculty members in the classroom as well as in the social life of the college.

MRS. MARY C. MARKLE is the Director of Music. A graduate of Ohio Wesleyan University's college of music, Mrs. Markle has been very successful in conducting the musical activities. The music department has shown much progress under her thorough and efficient service. Mrs. Markle is noted for being so pleasant and agreeable.

DAVID H. MARKLE is a new member this year too. Dr. Markle is assistant professor in education. He received his A.B. from Ohio Wesleyan University, his B.D., A.M., and Ph.D. from Yale University. Dr. Markle enjoys the college social activities and is well liked by all the students.
PROF. HOWARD E. THOMPSON is a new member this year to the faculty as director of the new Health and Physical education department. Mr. Thompson graduated with an A.B. at Spring. field College, Mass., in 1938. He received his M.A. at Ohio State University. Mr. Thompson is interested in establishing an efficient physical education program here. Track was started this year and football is to be brought back possibly in 1942.

MRS. ELOISE M. KLING, professor of Elementary Education graduated from Wittenberg College. Before coming to Cedarville, she taught in Springfield and Clark County Schools, in Ridgewood Private school and Ridgewood Experimental school. Mrs. Kling received graduate work from Columbia University.

Each year she guides elementary students along the road to student teaching. Mrs. Kling is faculty advisor for the Alpha Theta Tau sorority and has been doing a real service for the college and students.

MISS EMMA FORCE is the other professor of elementary education. Miss Force attended Wooster College, Kent State Normal, Ohio Northern University, Ashland College, and Western Reserve University. In addition she has a B.S. and M.A. from Ohio State University.

She has a State Elementary Life Certificate. On top of all the work Miss Force does at the college she teaches Art in the Cedarville public schools. 


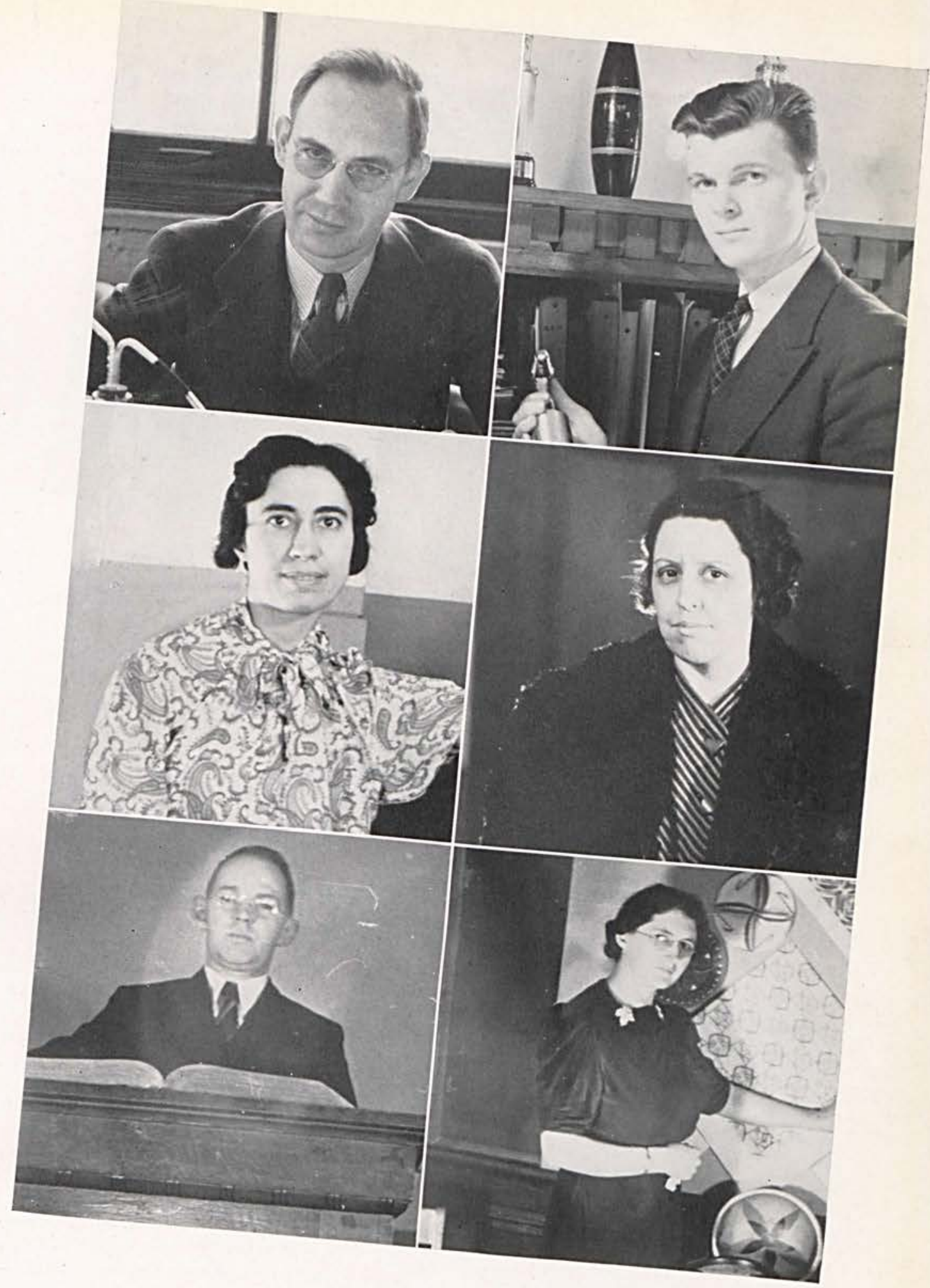

E. R. GIBSON

MARY C. MARKLE

DAVID H. MARKLE
HOWARD E. THOMPSON

ELOISE KLING

EMMA FORCE 

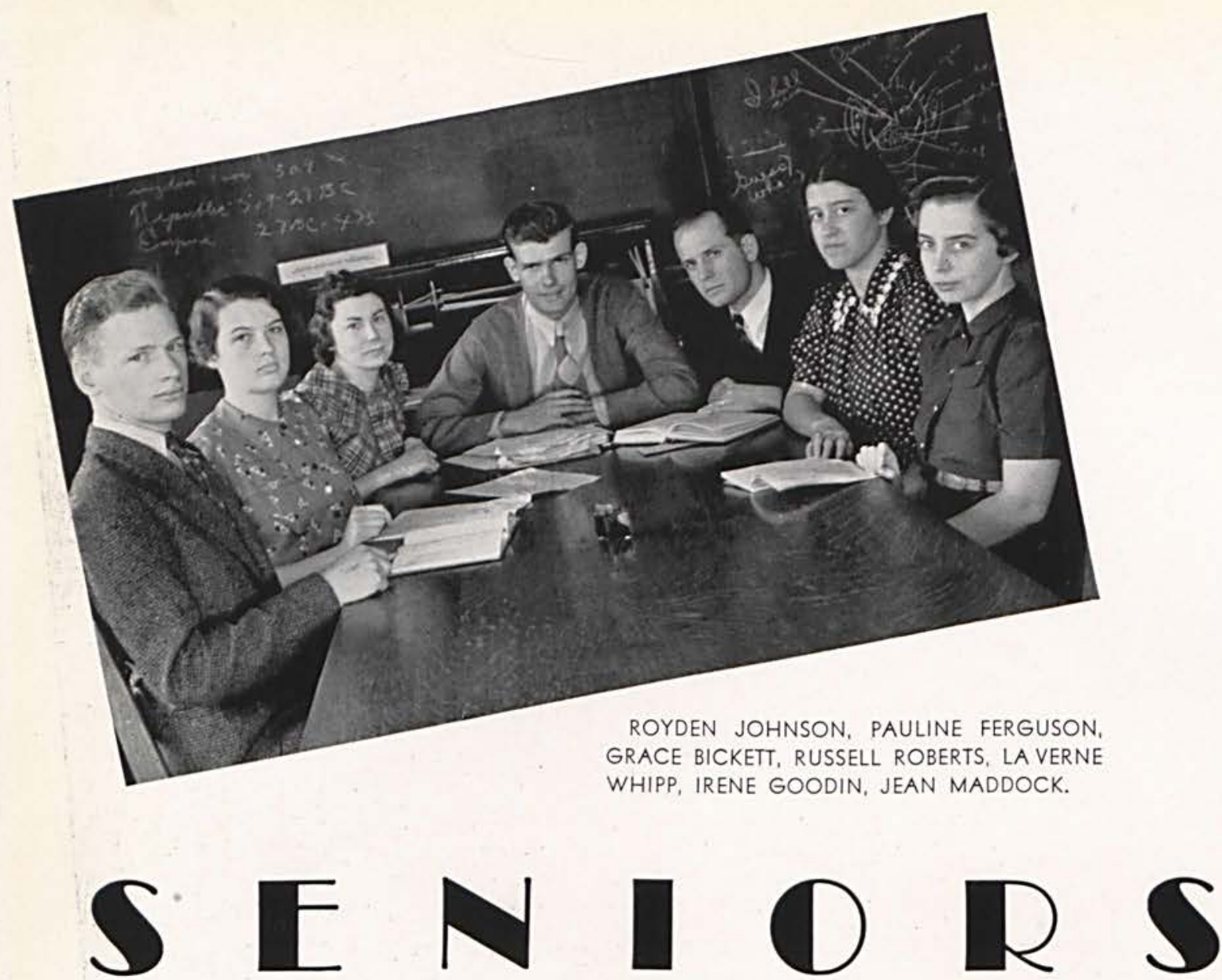

\section{CLASS OF 1940}

Four years ago forty-two freshmen embarked on their college career. We survived Willow Bend, cleaned off the steps of the Main building - for once, - and then we felt at home. Eldon Gillespie as our president, very ably guided us through our freshman year.

With a number not much diminished we entered upon our sophomore year with as little mercy for the incoming class as we had received the previous year. Under the leadership of John Peterson we made our presence felt in the fields of athletics, dramatics, Y.M.C.A., Chi Sigma Phi, Alpha Theta Tau, Delta Kappa Sigma, and Gospel Team. John Peterson and Donald Foulks sang with the college Harmonizers.

Mary Jane Hampton and Bette Allison both were married and withdrew from college.

In the fall of 1938, our number much decreased by the previous June commencement, twelve of us returned. This year Russel (Lanky) Roberts was chosen as president. The high spot of this year was the banquet given the Seniors by our class, at the Y.M.C.A. in Dayton. Another case of matrimony appeared with the announcement of the marriage of Donald Foulks and Katherine Smith of Waynesville.

September 1939 found 10 Seniors back in harness-the last lap of the journey toward a degree and a job. Russel Roberts was again elected president of the class as well as Student Body President. Mr. and Mrs. Foulks announced the arrival of a daughter and the Laverne Whipp-Margaret Ott romance culminated in marriage early in the new year.

Our class has been decreased by one-fourth during our four years at C. C. Survival of the fittest? Perhaps-. 
Pictured below is some of those in class room management, which is typical of senior classes in preparation for teaching. We have worked hard in preparing ourselves for the teaching profession. We have all taken our turn at practice teaching which is an experience none of us will ever forget.

In closing we all sincerely hope that none of our pupils see what is written on this page.

Back Row: GILLESPIE, FERGU. SON, SHAW, BICKETT.

Front Row: JOHNSON, ROB. ERTS, MADDOCK.

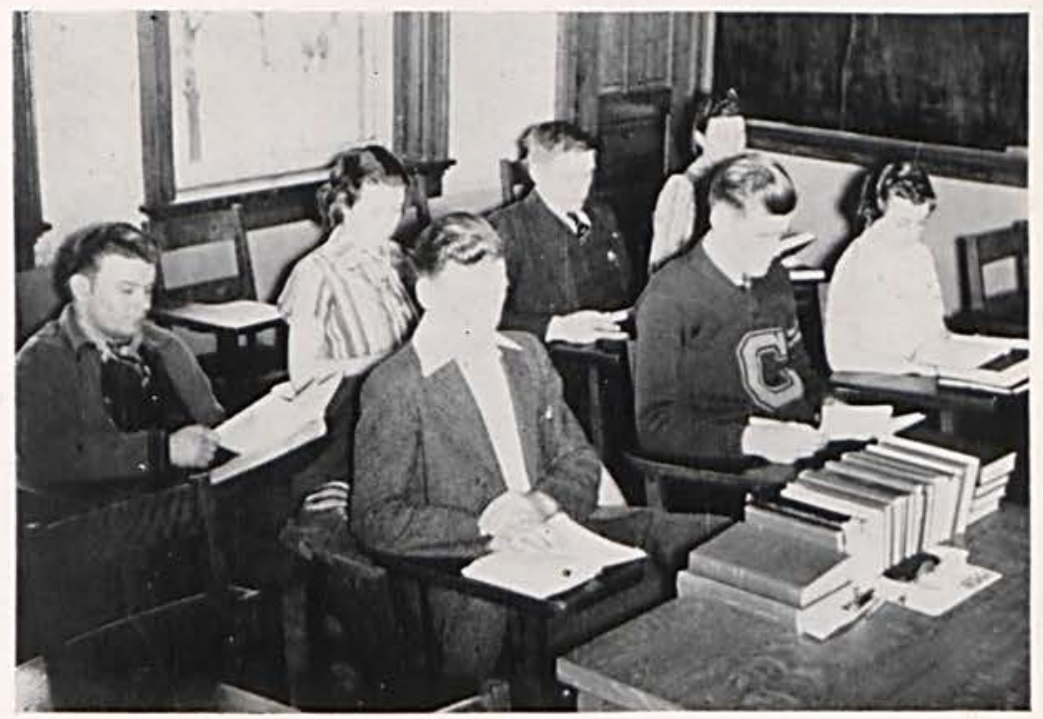



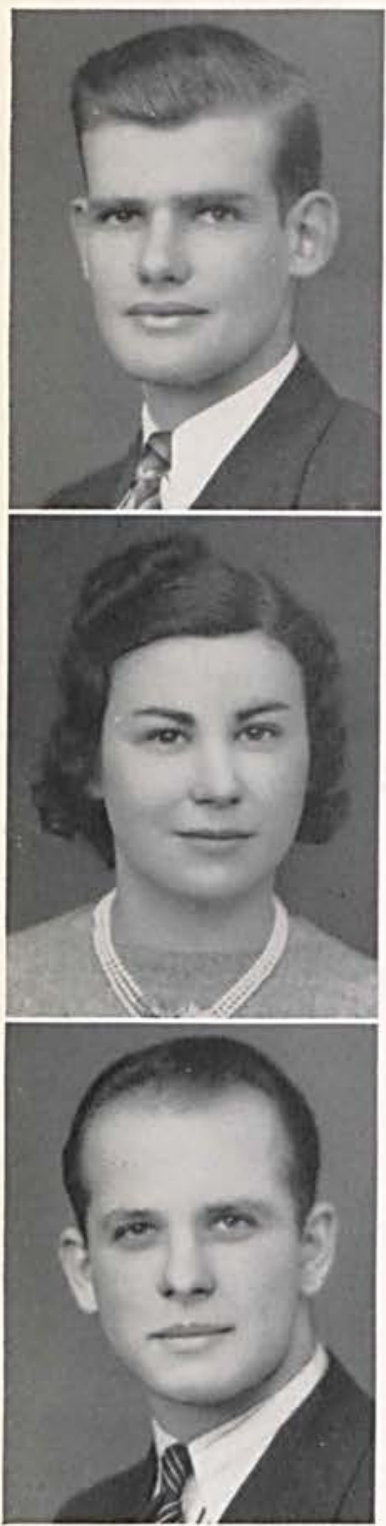

RUSSELL ROBERTS

GRACE BICKETT

LA VERNE WHIPP

Lanky is one of our most popular graduates. He has been active in many activities, a star basketball player, and this year is president of the student body, Y.M.C.A., Senior Class and the Varsity "C". He is also editor of the Cedrus, and Class Orator.

Grace has been a most faithful member of the Class of ' 40 . She has been a member of the Y.W.C.A. four years and has held various offices in several activities. This year Grace is President of the Alpha Theta Tau Sorority.

LaVerne has been on the baseball team these four years, a member of the Y.M.C.A. and has held several class offices. Whipp is well-liked and is always ready with a witty remark. We hope he is most successful in getting a job for next year.

Jean Maddock is a newcomer to our ranks this year. She is quiet and doesn't say much but is always willing to help whenever called upon. Jean will get her degree at the finish of the summer term.

Don is our most accomplished speaker. Therefore, he has been active in the Y.M.C.A. and the Gospel Team for all four years. In athletics, he played four years of baseball and two years of basketball. He was a member of the Men's Quartette three years and the Mixed Chorus two years. He too will be anxious to find a position.

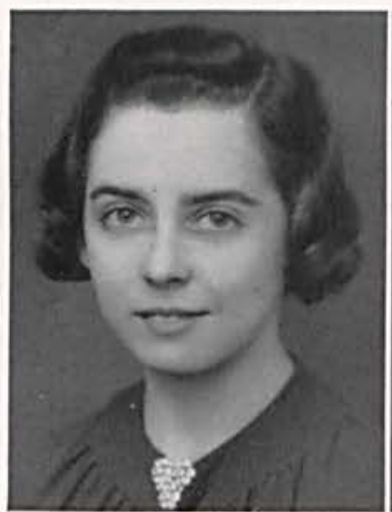

JEAN MADDOCK

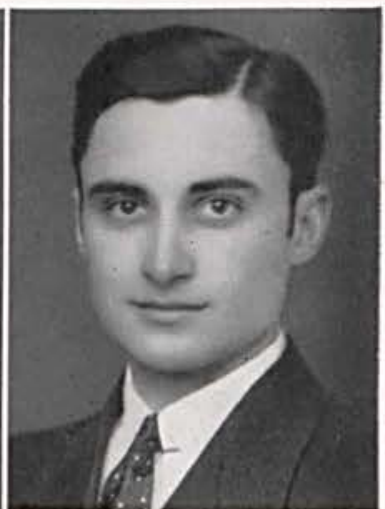

DONALD FOULKS 
Eddie has been our happy-go-lucky member. He belongs to several organizations. In athletics is his prowess, he has been a regular on the baseball team for four years, and on the varsity squad in basketball the last two years.

Pauline is one of our best students. She has been very active in college activities. This year she was president of the Y.W.C.A., she is a member of Chi Sigma Phi Sorority. Pauline is very pleasant and is always willing and eager to give her best services at all times.

Royden is a member of the Y.M.C.A., Gospel Team, Mixed Chorus and the Men's Quartette. Royden is another one who will be after a job teaching mathematics. Although he didn't take part in athletics, he made up for it in other college activities.

Irene is a hard worker. Sta has done secretarial work for Professor Steele the last two years. She belongs to the Y.W.C.A. and is a very active member of the Gospel Team. Irene doesn't back down from any task but says, "I will do the best I can."

Elwood has a subtle humor and is frequently coming up with some outstanding remark. He didn't care for varsity sports except track but he did like to take part in intramurals. Elwood is a fine young man and deserves a chance to succeed.

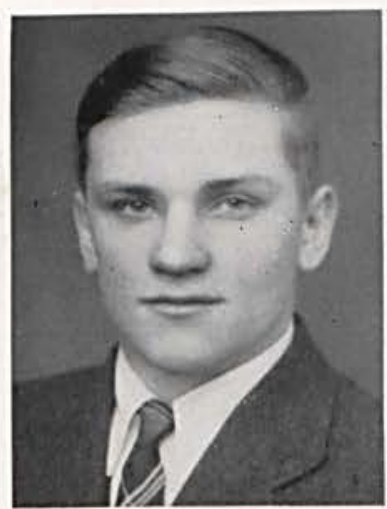

ELWOOD SHAW

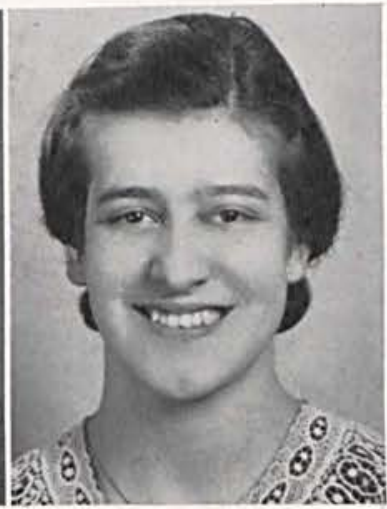

IRENE GOODIN
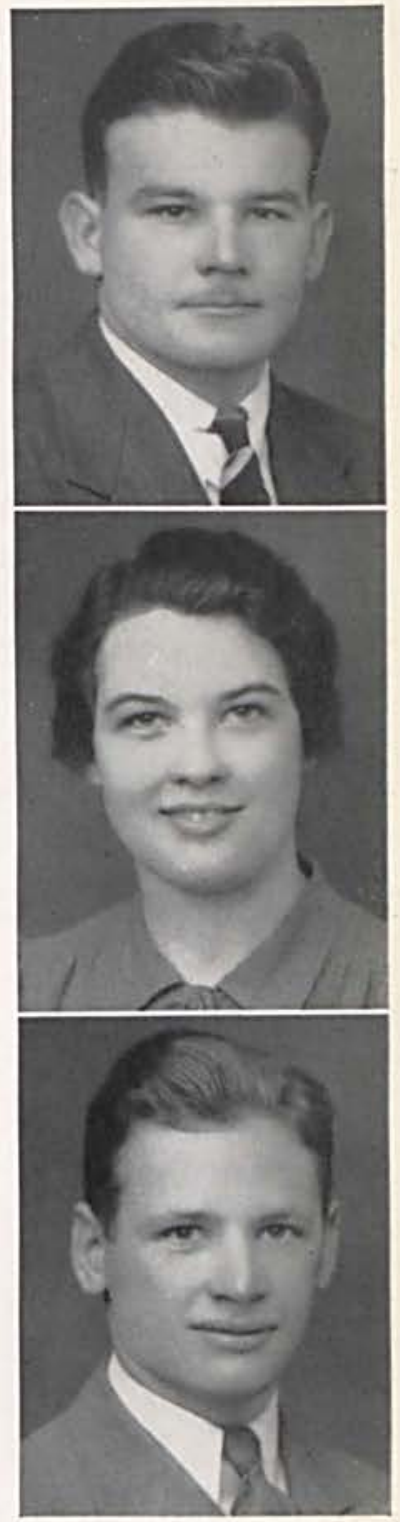

ELDON GILLESPIE

PAULINE FERGUSON ROYDEN JOHNSON 


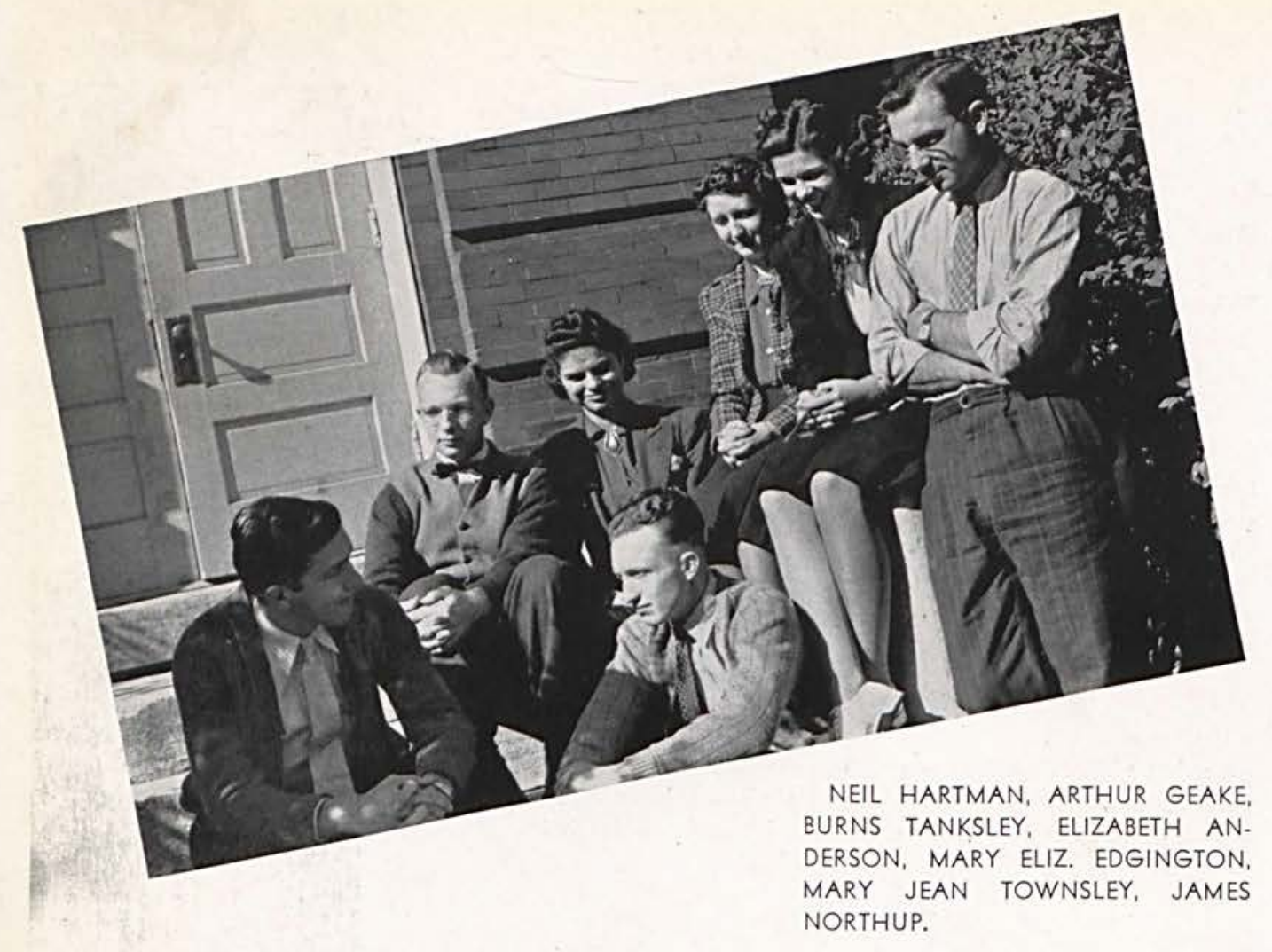

\section{- JUNIOR CLASS HISTORY}

\section{JUNIORS}

Only three short years ago, forty-two homesick "Freshies" received their first taste of college life. We were not so eagerly looking forward to the initiation we were about to receive; however, under the capable guidance of Richard McKnight we managed to pass over the rough spots of that first year.

Last year found us a little more sure of ourselves, and under the direction of Clayton Wiseman we were well represented in all college activities.

This year many of our number failed to return due to the call of the teaching profession. Again we are well represented in college activities. Seven of our boys played basketball and three baseball. "Hal" Thomas was one of the mainstays of the newly formed track team.

We are eagerly looking ahead to our senior year.

\section{Burns Tanksley,}

Class Reporter.

Helen Chitty finds it hard to study here.
Theodora Smithers takes a thoughtful position.
Arthur Geake certainly must have his lesson.
Harold Thomas with that eight o'clock just over.
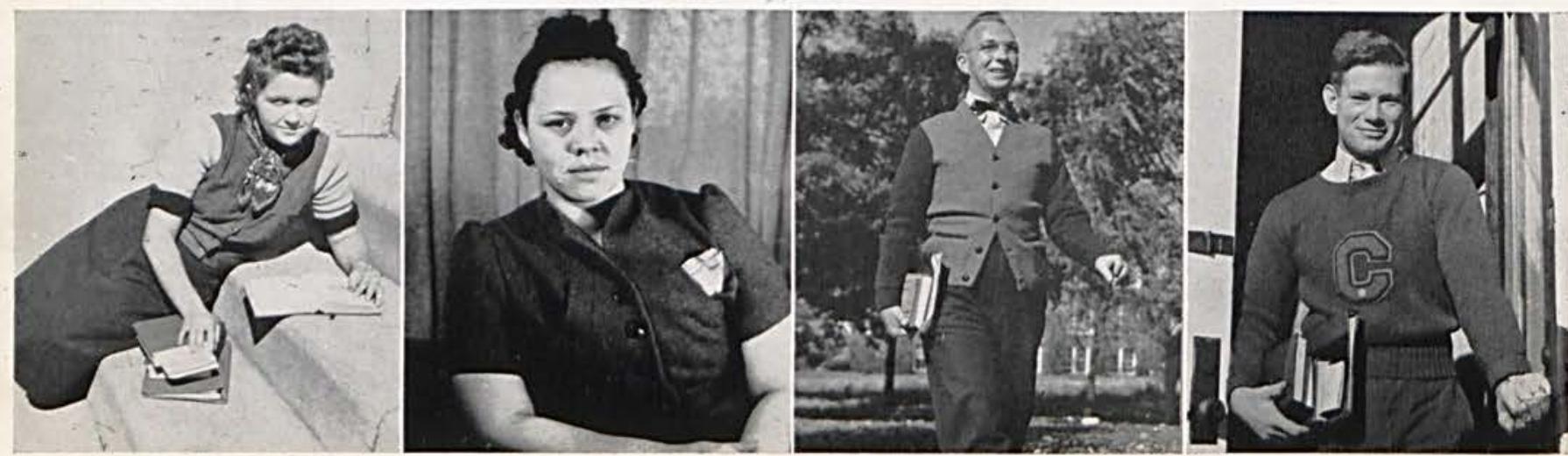


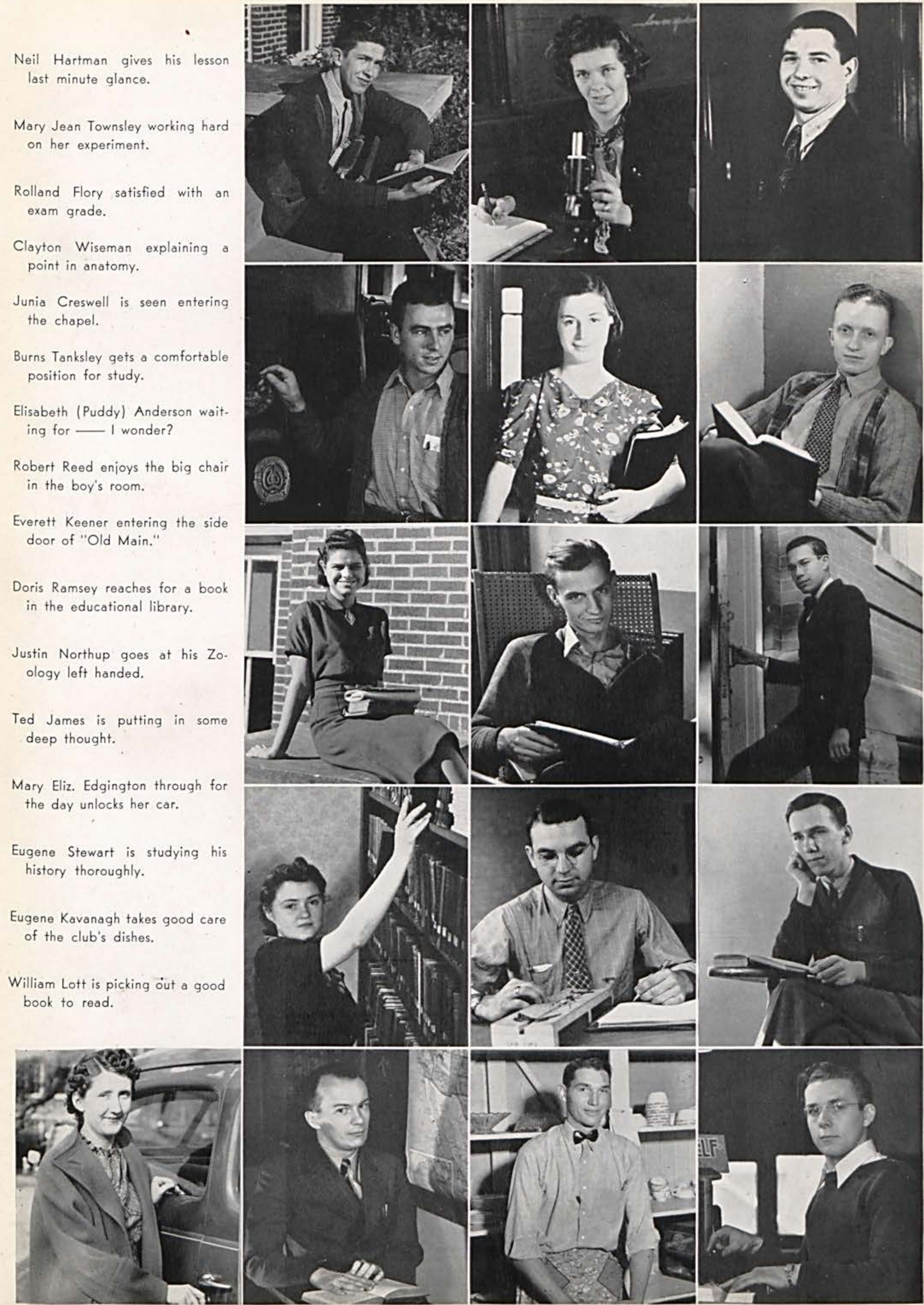




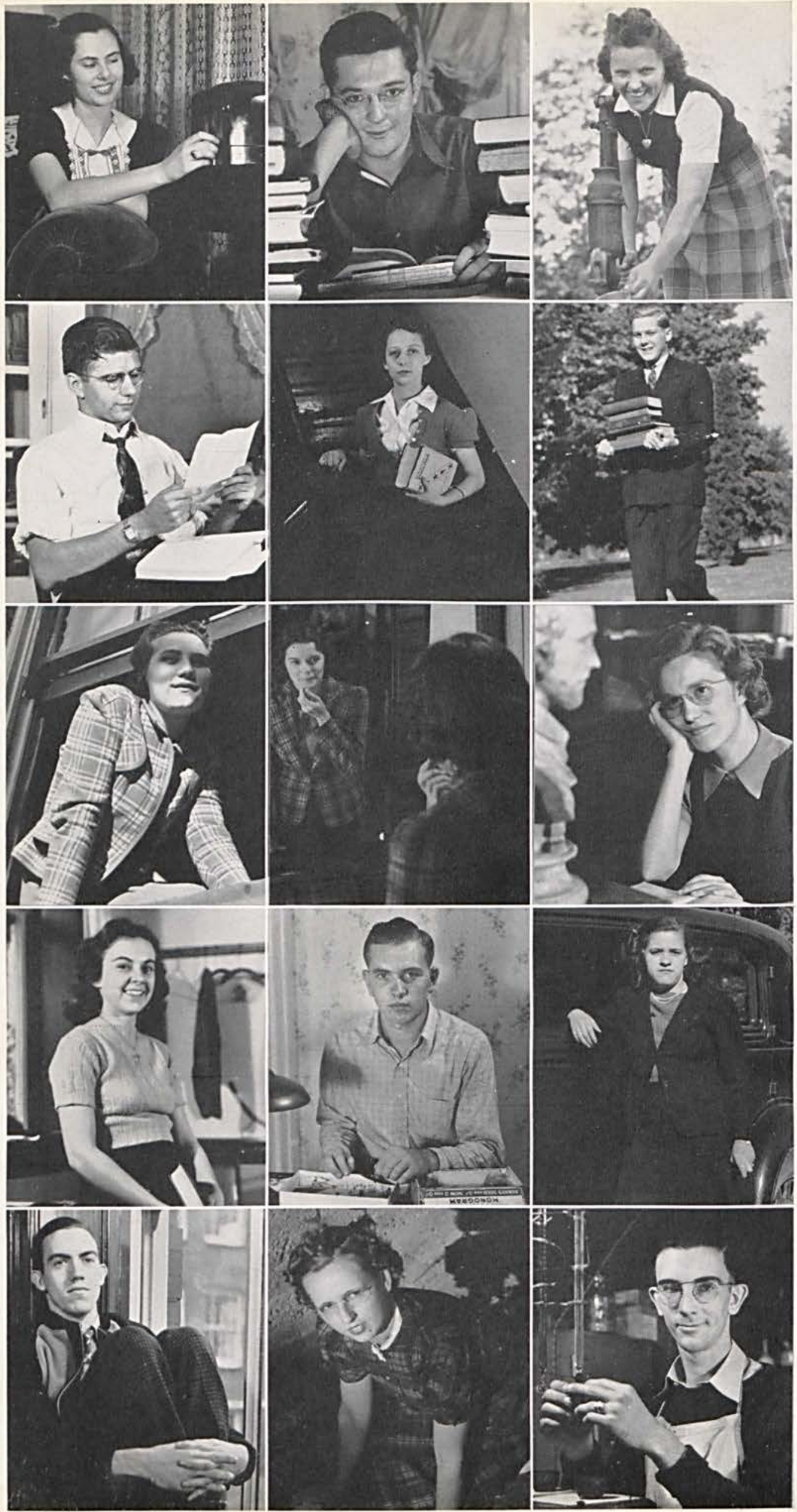

Isabel McClellan getting a good program on the radio.

John Brill settles down to an eve- y ning of study.

Margaretta Lott gets a drink at 4 the old college fountain.

Robert Guthrie receives a letter from the girl back home.

Mae Stebbins pauses at bottom of stairway in "Old Main."

Willard Bennington comes down the walk with some of his books.

Kathryn Randall takes a comfortable position in the girls' room.

Jeanette Neal puts on some makeup before going to class-Oh yeah!

Virgie Gossard looks dreamily at Mr. Shakespeare.

Orsadee Stewart has on a pretty smile for some reason.

Norman Linton works hard on his zoology.

Hazel Bush just arriving at school.

Ralph "Lucky" Logan takes it easy in the library window.

Anna Louise Ritenour gets ready for a good start in her sophomore year.

John Reinhard found in the mid dle of a chemistry experiment. 


\section{SOPHOMORE CLASS HISTORY}

The Class of ' 42 was first greeted as "Freshies". early in September 1938. After the much feared initiations became history we were accepted as members of ol' C.C.

Beginning a new year in the fall of ' 39 with one of our memorable steak fries we were off to a "flying start." We lost several members from our Freshman Class but new ones took their places. We have had many enjoyable times together: steak fries, skating parties, dances, and a hay ride filled our calendar.

We have been well represented in extra-curricular activities. Almost all the girls took an active part in the Y.W., the Sororities, and in the intra-mural sports. All the boys took part in intra-murals. Our class was represented in Varsity basketball by "Whitey" Linton and Ned Brown. Guthrie, Wilson, Linton, Brill, Brown and Reinhard were our contribution to the baseball squad. We hope they will all be back next year to help make an even greater athletic history.

We are looking forward with eagerness to our coming Junior year. May it be as full of happiness as the last two have been.

\section{SOPHOMORES}

Vuna Ruth West is seated at the piano in the chapel.

Mary Elizabeth Batdorf has two pictures in one.

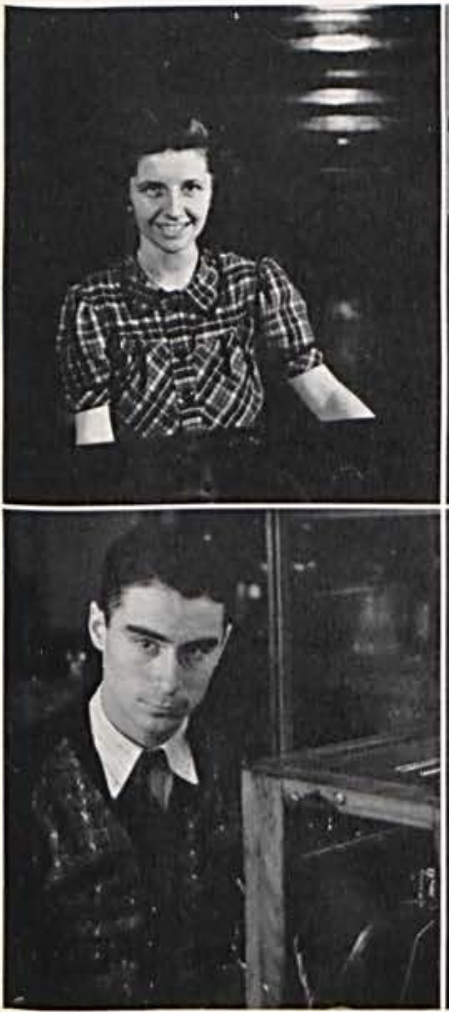

Helen Ross looks the world over.

Janice Finke gets some valuable information.

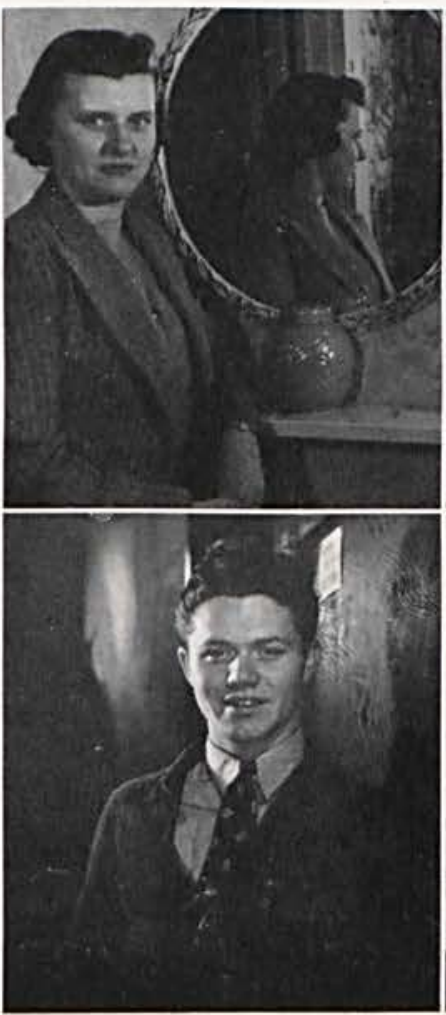

John Bickett does some expert weighing.

Ned Brown keeps an eye on the bulletin board.

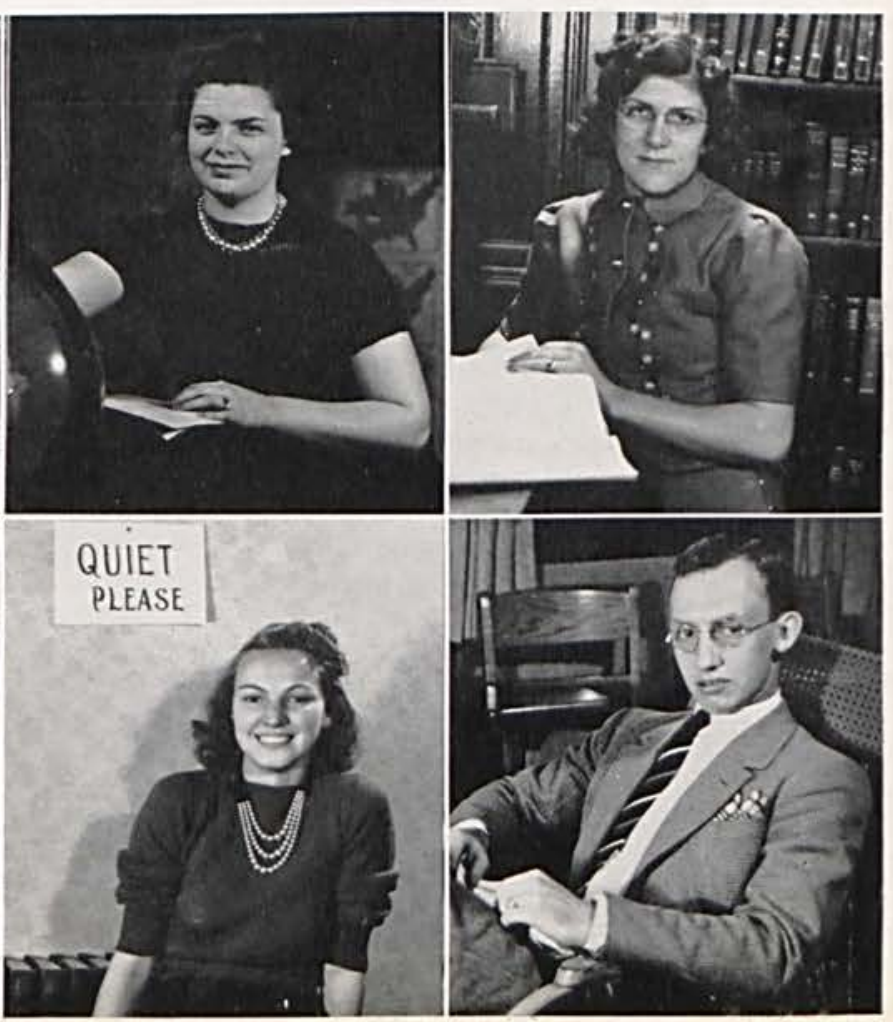

Betty Nelson here, doesn't see the sign.

Layden Wilson does some leisurely studying. 


\section{FRESHMAN CLASS}

\section{FRESHMEN}

On September 6, 1939, twenty-four freshmen embarked on their college careers at dear old C.C. In the second week they elected as president Montgomery West; vice-president, Hank Foster; secretary, Jane Jolley; treasurer, David Galey; intra-mural representatives, Anna Lee Long and Lee Miller; class reporter, Vincent Rigio.

Freshman week was highlighted by Vince Rigio's 40 mile ride and the tug-of-war which the freshmen would have won if the sophomore girls had not aided their classmates in pulling the frosh through the water. The year's activities included the freshman feed, a dance and two skating parties. The class of ' 43 distinguished itself in intramural sports, running a close second to the Juniors. It supplied much of the material for the undefeated girls' basketball team and the men's varsity and junior varsity basketball; baseball and track teams.

The start of the second semester, Christian Arnold and Eileen Brown added their names to the class roster bringing the total to twenty-six. The year as a whole was pleasant with only a few difficulties. We look forward eagerly to next year, hoping that it will be as enjoyable as this one.

Henry Foster, vice-president.

Beatrice O'Bryant picks out a good book.

Betty Lee Garrison takes time out for a candy bar.
Joe Corn reads up on the track news.

Vincent Rigio finds a cool place.
Montgomery West keeps an eye on 1 wonder?

Anna Lee Long records some observations.
Lillian Gilliam sure looks comfortable here.

LeRoy Haynie gets some instructions for work from $\mathrm{Mr}$. Owens.
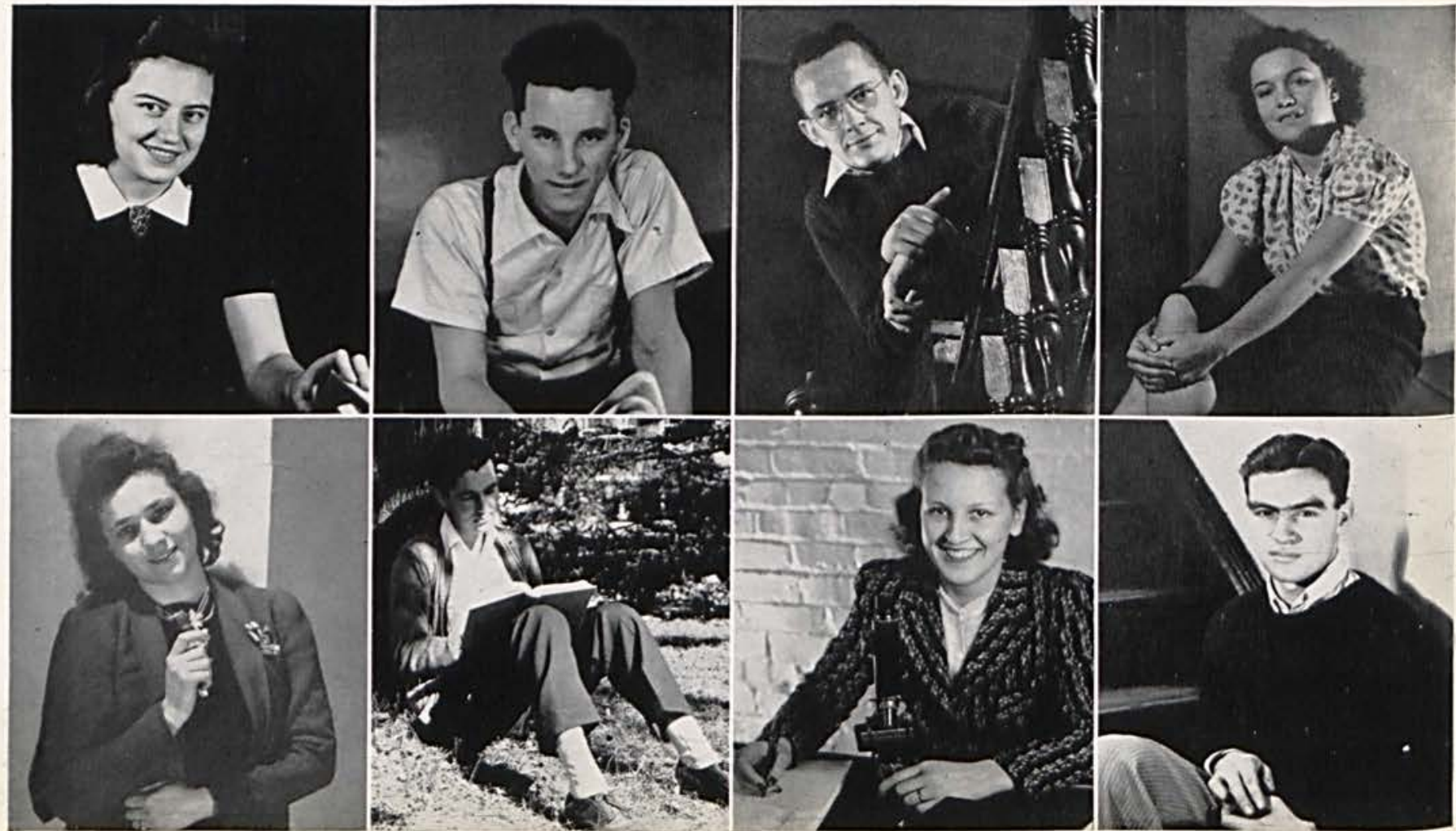
Warren Taylor sets his watch with "Old Faithful."

Henry Foster holds up the college sign.

Betty Irvin gets a drink in the Science Hall.

Double trouble here-Oh, yes, the Flory twins-Merrill and Laurrell.

Dave Galey the Romeo-poses in the boy's room.

Lee Miller working hard on those lessons.

Helen O'Bryant is just leaving a class.

Alfred Fehlmann has some science to look up.

Helen Tanksley seems to enjoy studying here.

Beatrice Williams is at ease with classes over for the day.

Catherine Ferguson is an expert typist.

Martha Jayne Spahr keeps an eye on the High School.

Marion Muller is found pounding out a tune.

Dorothy Bogenrife takes it easy between classes.

Jane Jolley making final prepara tions for Mr. Hostetler's class.
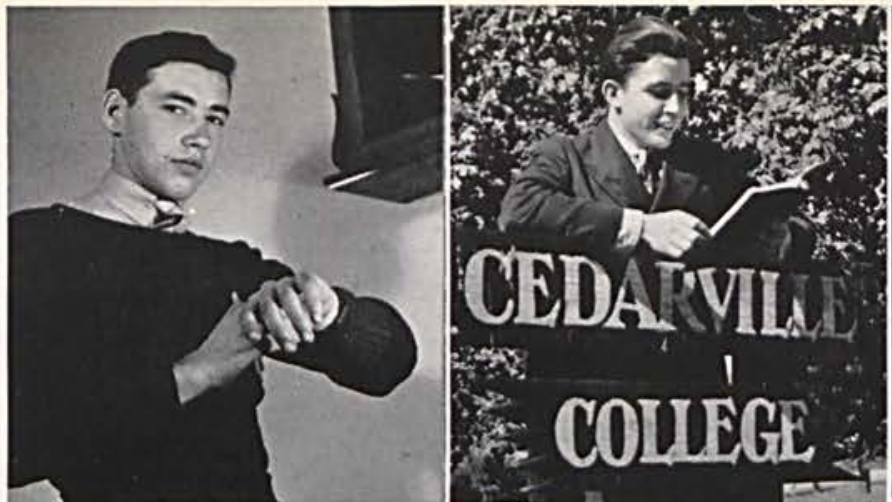

CED

ixos

COULEE
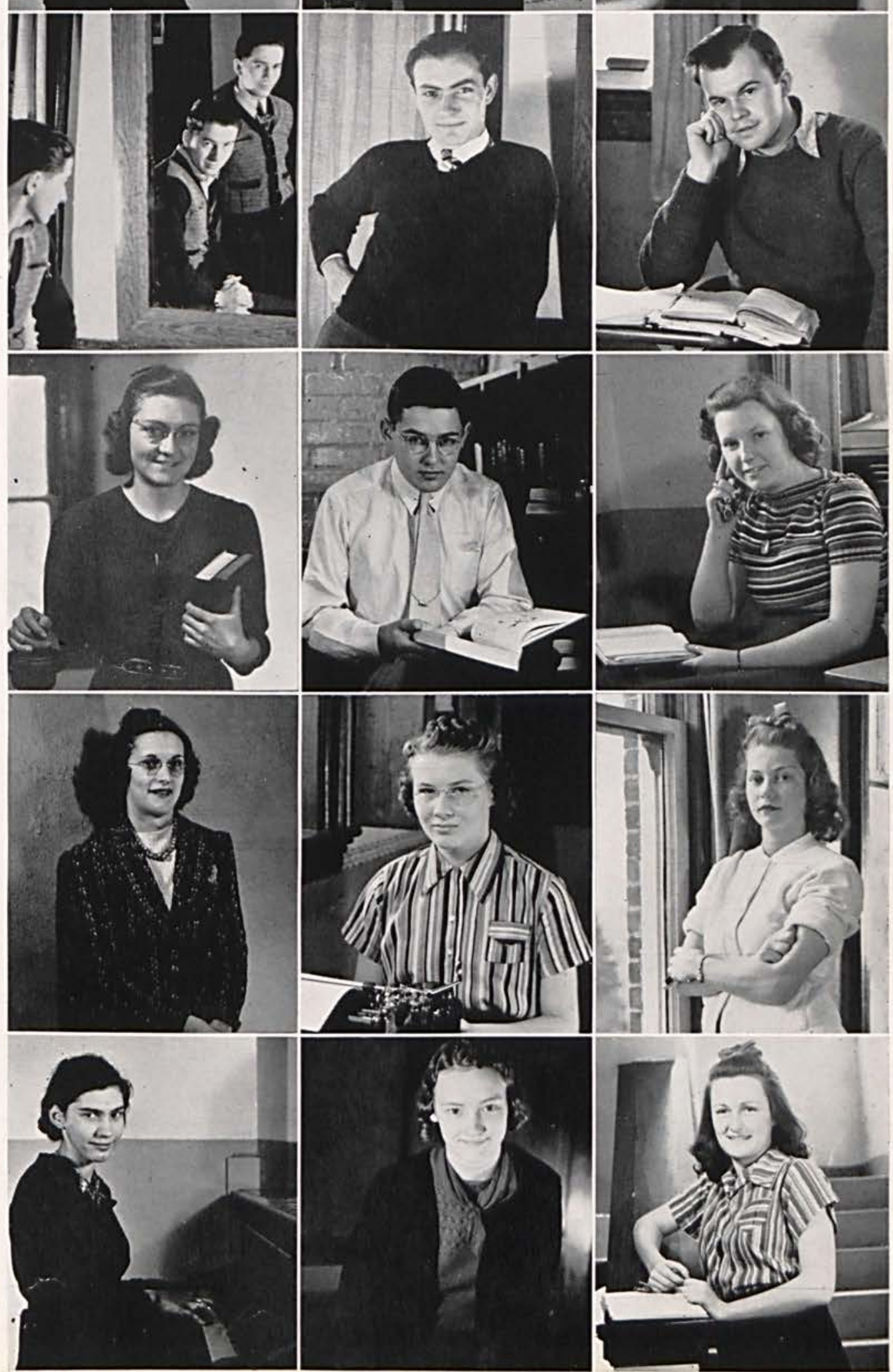
BOOK TWO

Their Athletics varsitr 


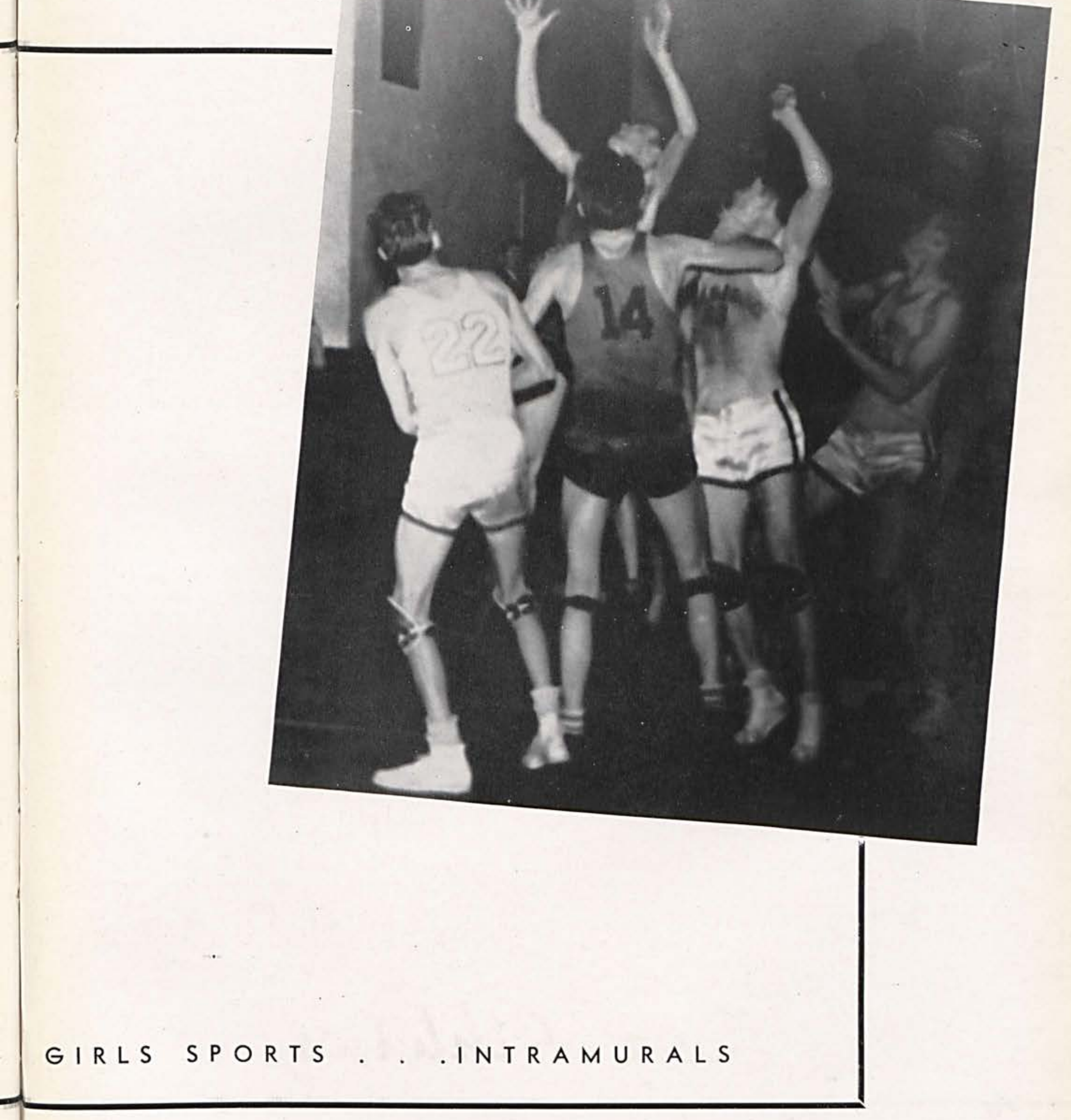




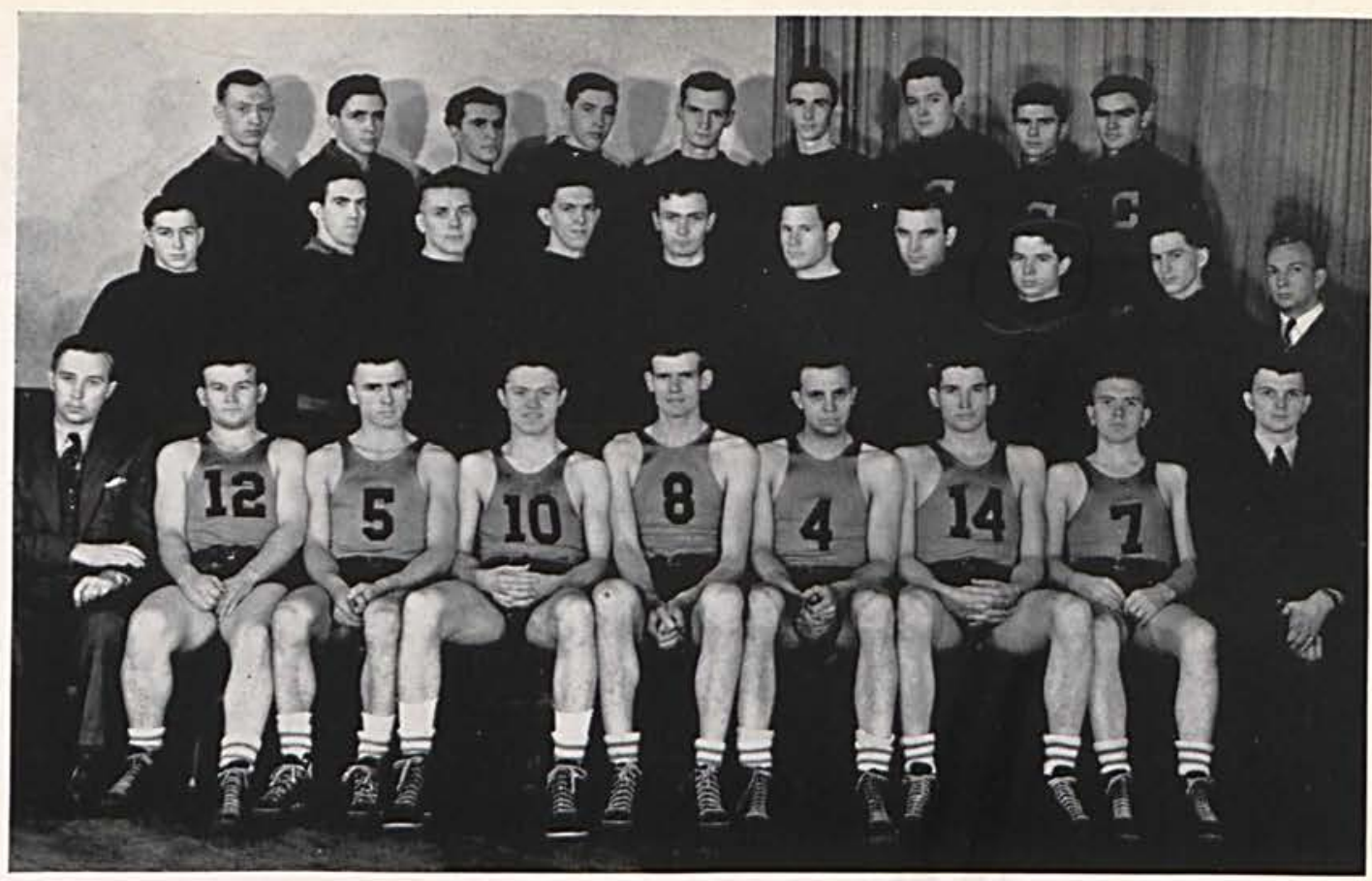

Wilson, Foster, Rigio, Taylor, Reed, Rinehard, Brill, Guthrie, Haynie, M. Flory, Logan, Lott, Hartman, Galey, Thomas, Northup, R. Flory, L. Flory, Geake, (Mgr.). Coach Miller, Gillespie, Wiseman, Brown, Roberts, McNeal, Kavanagh, Linton, Thompson (Director of Physical Education.)

Seemingly by way of proof to some of those who doubted the strength of the Cedarville Yellow Jackets, the same team that rode to victory last year, early began to again erase any doubt from the minds of the most skeptical as to their true worth.

Kavanagh, Roberts, Brown, McNeal, and Wiseman began the year in their customary manner, but a series of mishaps and changes soon put the names of Linton, Hartman, Moore, and Thomas on the line-up.

It was especially after the half year that the team developed into a well-organized squad and settled down to the task before them. It is doubtful if any coach can boast of a squad of equal potentialities, and much credit is due Miller for his efforts in the development of plays which best suited his men.

Highlights of the season include a victory at Otterbein, a memorable trip to Miami University, the ever-to-be-remembered Homecoming game with Holbrook, a thrilling over time game with Wilberforce that ended in victory and the final game, when "Lanky" Roberts, our gráduating star, showed why he and "Tuny" Kavanagh won Honorable Mention as forwards on the Associated Press' mythical All-State Team.

Harold Thomas,

Sports Editor. 


\section{STATISTICS OF THE SEASON}

\begin{tabular}{|c|c|c|}
\hline Springfield Y......... 41 & C.C. 48 & Tiffin $\ldots \ldots \ldots \ldots \ldots . \ldots .37$ C.C. \\
\hline Otterbein ...........4 41 & I C.C. 43 & Rio Grande ........ 38 C.C. \\
\hline Urbana ... & 7 C.C. 47 & Holbrook .. \\
\hline Wilberforce & I C.C. 45 & Springfield $Y$.. \\
\hline Morehead & 8 C.C. 43 & Rio Grande .. \\
\hline Holbrook & 2 C.C. 28 & Wilberforce \\
\hline Wilmington & 4 C.C. 28 & Bluffton ....... \\
\hline Bluffton & 6 C.C. 35 & Wilmington . \\
\hline Siffin & 2 C.C. 42 & 32 C.C. \\
\hline Miami & 8 C.C. 27 & 25 C.C. \\
\hline
\end{tabular}

\section{OUR CHEER LEADERS}

We contribute a great measure of the success of the team this year to our two most efficient cheer leaders, Jane Jolley and Bette Lee Garrison. Dressed in their new colorful uniforms these girls furnished the "oomph" to give the boys the will to win. They showed great ability by the loud yells they brought forth from the small crowd that followed the team. We are sure they deserve the frontispiece given them in this book.

Harold Thomas.

Roberts

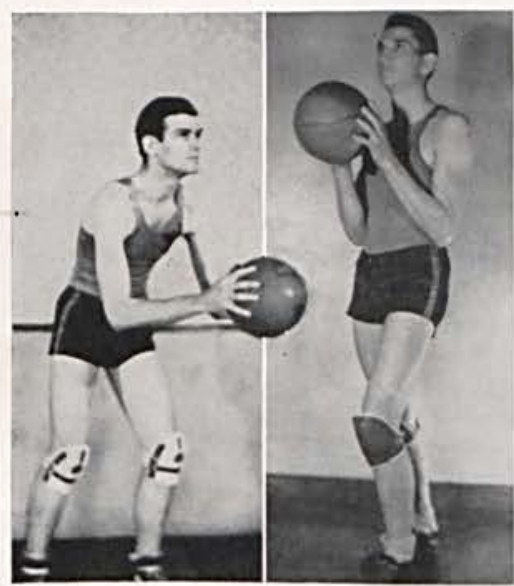

Thomas

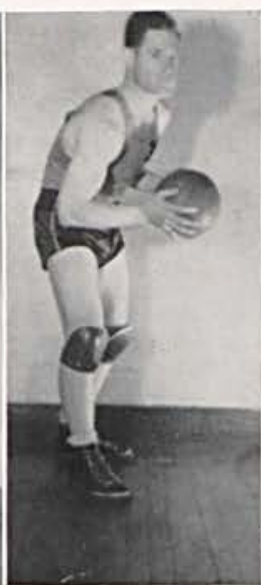

Brown

Linton

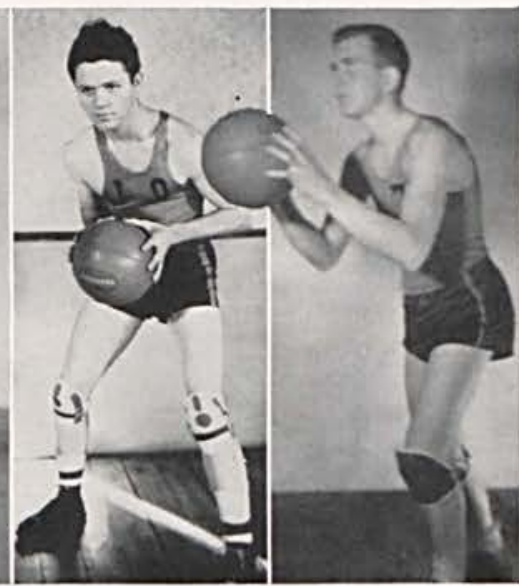




\section{BASEBALL SCHEDULE 1940}

\section{BASEBALL}

April $10 \ldots . .$. University of Dayton...........................

May $1 . . . .$. Wilberforce University...........................

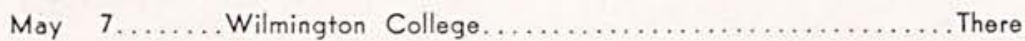

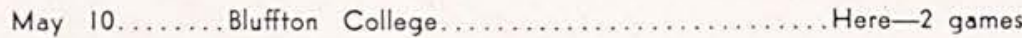

May $14 \ldots . .$. Bonebrake Seminary..................... Here -2 games

Moy $21 \ldots . .$. Wilberforce University........................ There

May 24........ Bluffton College.......................... There

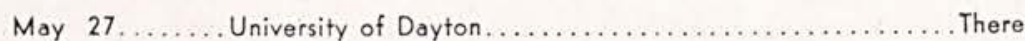

May 29........Wilmington College........................ Here

Although winning only five games out of a fourteen game schedule the 1939 baseball season was by no means a failure. The team as a whole had a batting average better than .300 with four members of the starting nine batting well over the .300 mark. The season was begun by splitting a double header with Rio Grande. Other games won were two with Bonebrake Seminary, one with Bluffton and one with Urbana University. In the final game of the season on Cedar Day the Cedarville nine were defeated by 'the close margin of 10-8 although they outhit the Wilmington nine.

In spite of the loss of five lettermen and two substitutes we are looking forward to a more successful season this spring. This year sees the return of Dayton University to the baseball schedule. Regulars left ovr from last year are Bob Reed, Eldon Gillespie, Harold Thomas, Justin Northup, and Ned Brown. This year as last the team will be under the leadership of Coach John Mills.

Harold Thomas.

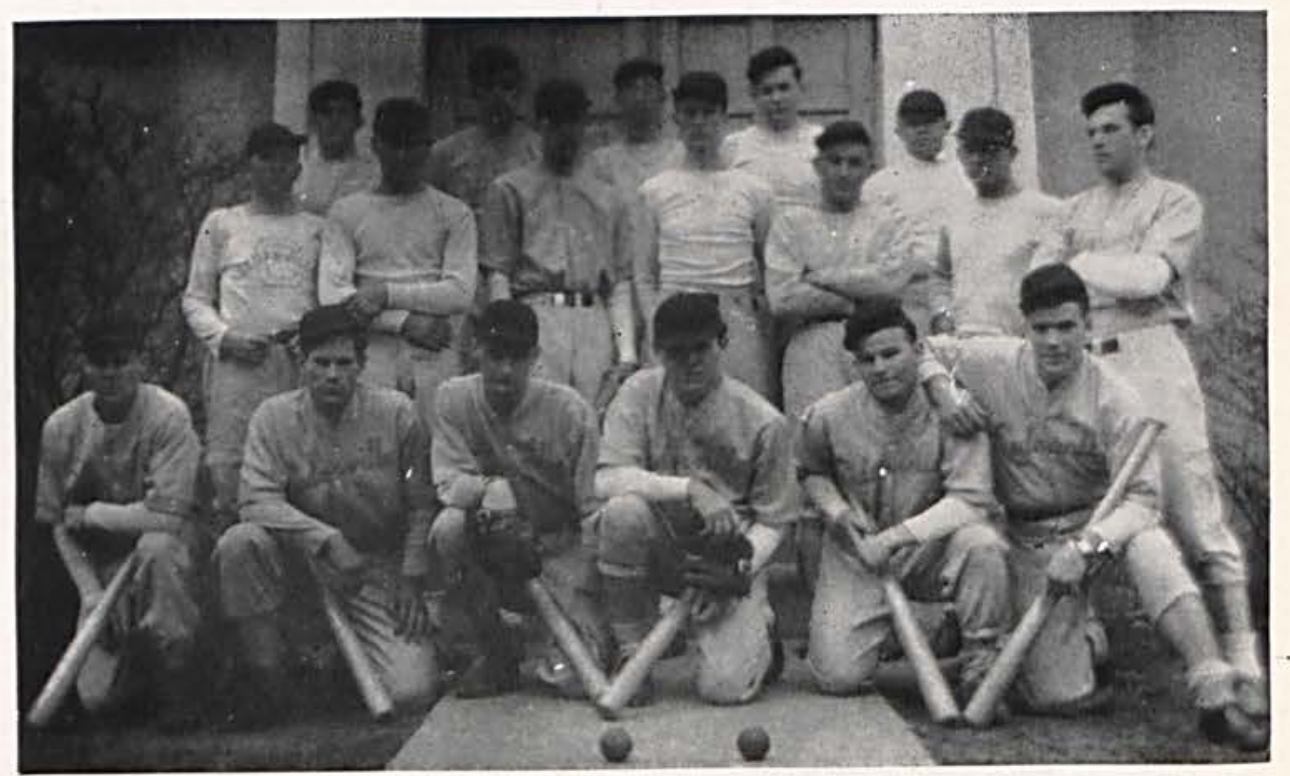


This is an entirely new college organization for boys. Any boy earning a letter in any sport is eligible to enter.

The club was organized early in September under the sponsorship of Howard E. Thompson, our new Health and Physical Education Director.

The charter members are Russel Roberts, Eugene Kavanaugh, Clayton Wiseman, Kenneth McNeal, Clyde Walker, Harold Thomas, Ned Brown, Arthur Geake, Bob Reed, Justin Northup, Don Foulks, and Eddie Gillespie. The officers chosen were Roberts, president; Walker, vice-president; Geake secretary; and Thomas, treasurer.

This club was organized to encourage friendship among all the boys in athletics. Several parties were enjoyed. As a highlight, the club sponsored a Fall Sports Dance to which the entire college was invited. Oh yes, none of the members will forget the "vinegar" and doughnuts we had at one of our meetings.

There will be several new members added next year to enlarge and promote a bigger and better Varsity " $\mathrm{C}$ ".

Russel Roberts, President.

\section{"C" CLUB}

BACK ROW: Geake, Walker, Thomas, Brown, Northup, Prof. H. E. Thompson.

FRONT ROW: Roberts, Kavanagh, Reed, Foulks, Gillispie.

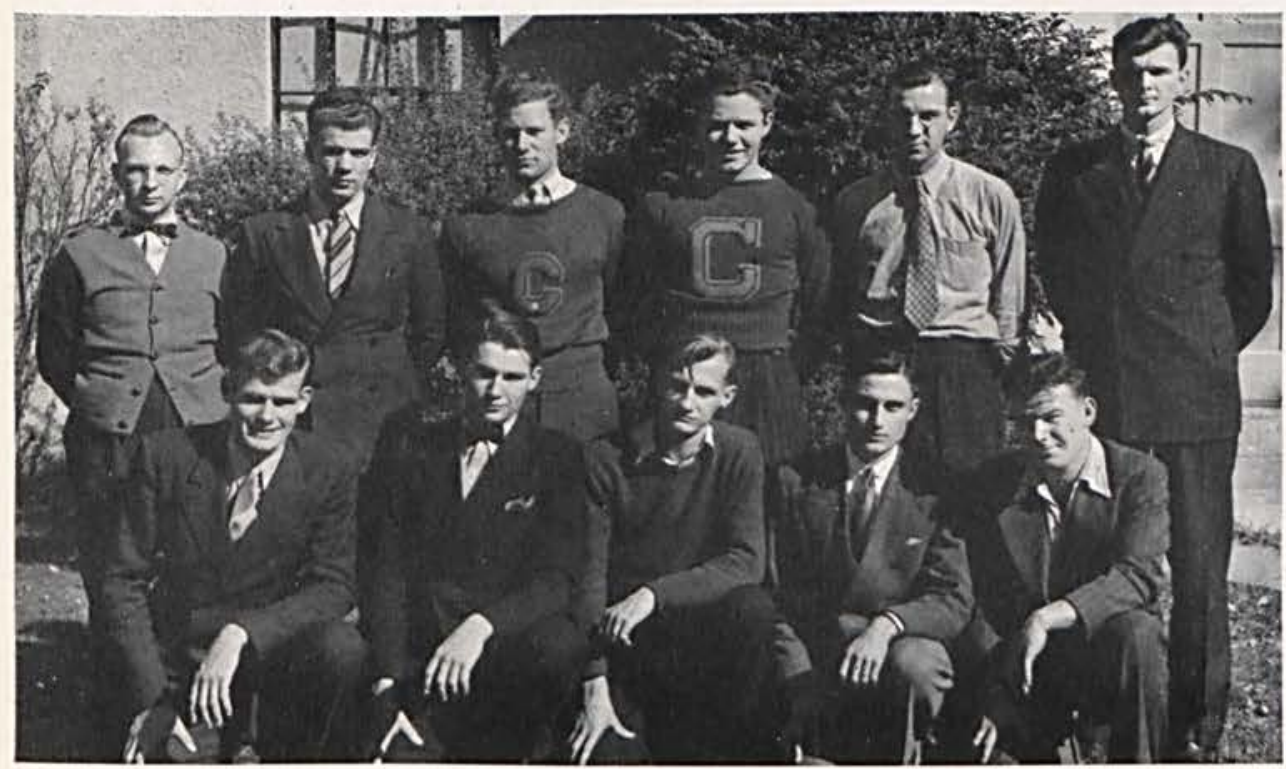




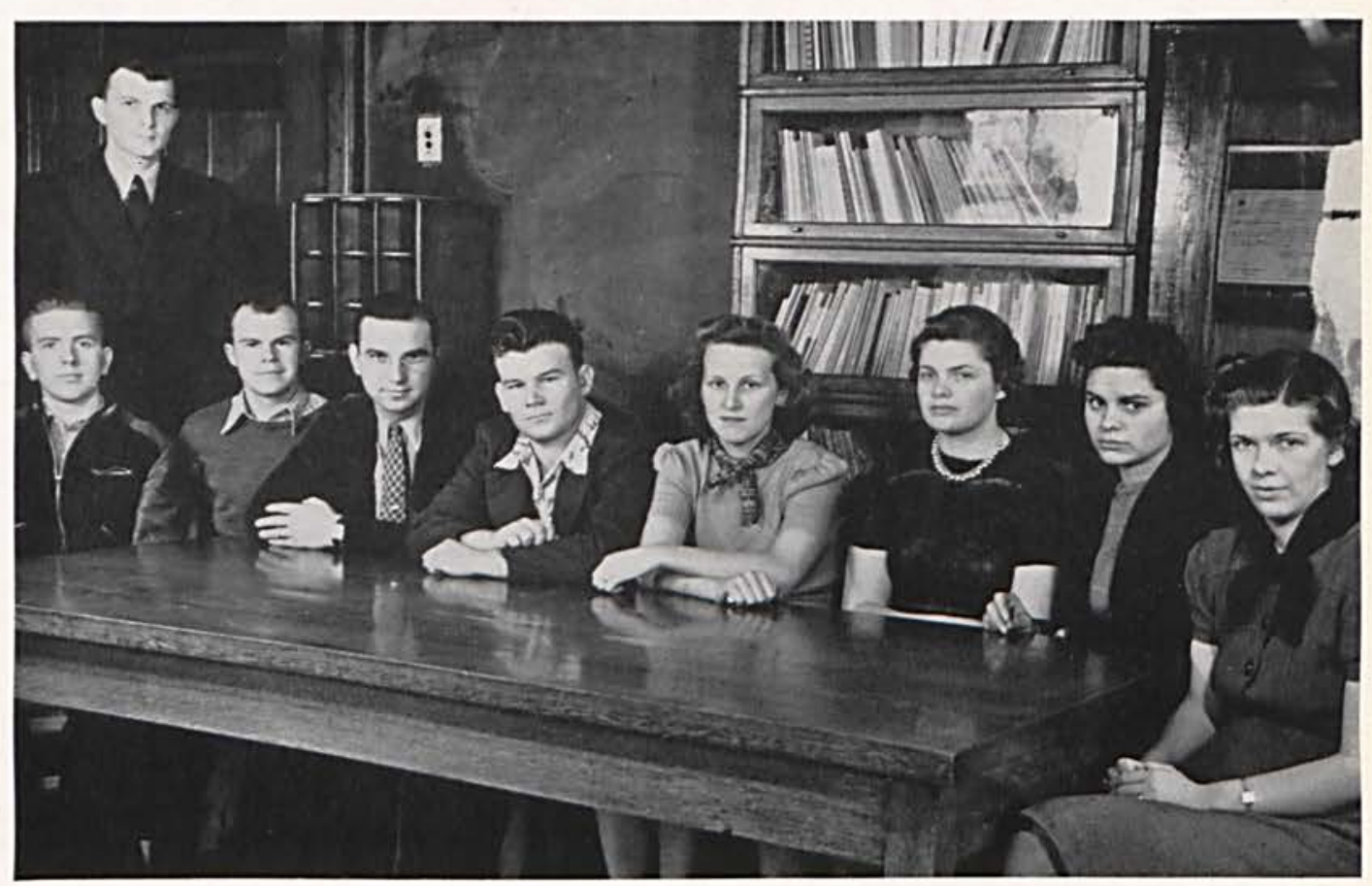

Linton, Miller, Northup, Gillespie, Long, Ross, Anderson, Townsley, Prof. H. E. Thompson, standing.

INTRAMURAL

BOARD

An Intramural Board of Control was organized to govern interclass activities. Eight of the ten members were elected by the student body, a man and a woman being selected from each of the four undergraduate classes.

A varied activity program was inaugurated with the following seasonal sports being staged: tennis, soccer, baseball, six-man touch football, volleyball, badminton, basketball, bowling, track, and softball.

It is the hope of the Department that soccer and speedball, as well as swimming be added to next year's program.

The following are the class results in the Intramural program. The class of 1941 led with thirty-eight and a half points. Strength in men's basketball, volleyball, and tennis, and in women's tennis and badminton gave the Juniors their lead. Close behind was the class of 1943, with thirty and a half points, all because of the athletic prowess of the "fair sex" of the yearling contingent. Next in order were the classes of 1942 and 1940 respectively. The former garnering twenty-seven points while the latter won twenty-four. 
Intramurals have become more popular and much more interesting this year. The Director of Health and Physical Education set up a definite program to follow. There were many events run off during the fall and winter months. An Intramural Festival was held in March for eliminations.

Some acrobatic stunts on the parallel bars.

Mr. Thompson gives a few pointers for six man football.
Here is a shot of an intramural basketball game.
Here a play is being run off.

Getting set for the first play.

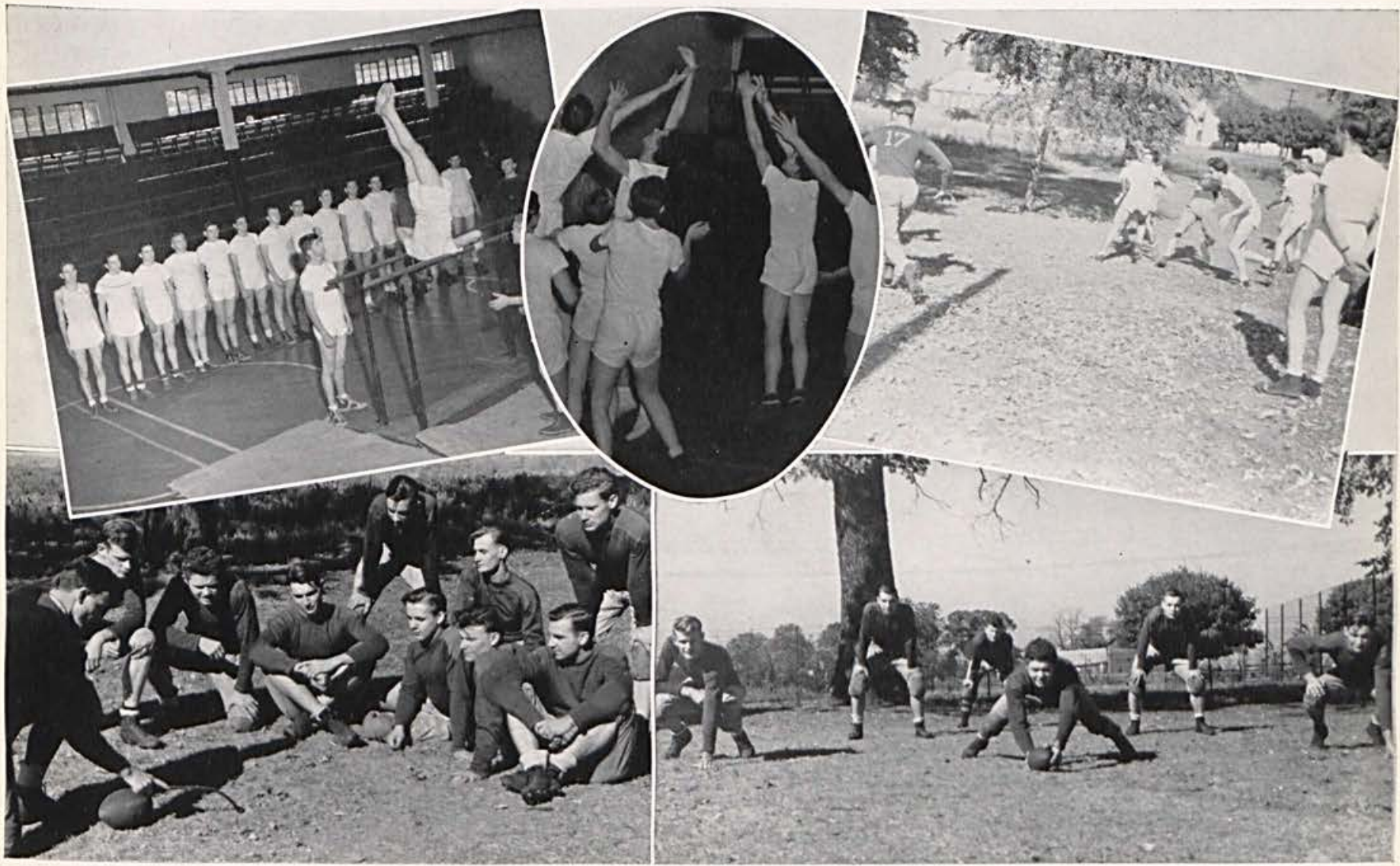




\section{PHYSICAL TRAINING}

The College year of 1939-40 saw the inauguration of the Department of Health and Physical Education under the supervision of Professor Howard E. Thompson.

The establishment of the Department was four-fold: first, that the College be able to grant a degree in the field of Health and Physical Education; second, to establish a more central unit for the administration of intercollegiate athletics; third, to organize and administer an intramural program and fourth, to enlarge the activity program of the College.

The college intercollegiate athletic program was doubled during the past year in that regular scheduled contests were arranged for the varsity track and tennis teams. It is also the hope of the Department that enrollment will someday be large enough to warrant the return of intercollegiate football.

The Department has already contracted several new changes for the grounds and the Gymnasium. A quarter-mile track and a field suitable for football and soccer is to be built on the large tract of land to the north of the Science Building.

With the addition of newer and better facilities and enlargement of the personnel, the Department of Health and Physical Education is looking forward to its place in the field of service. 


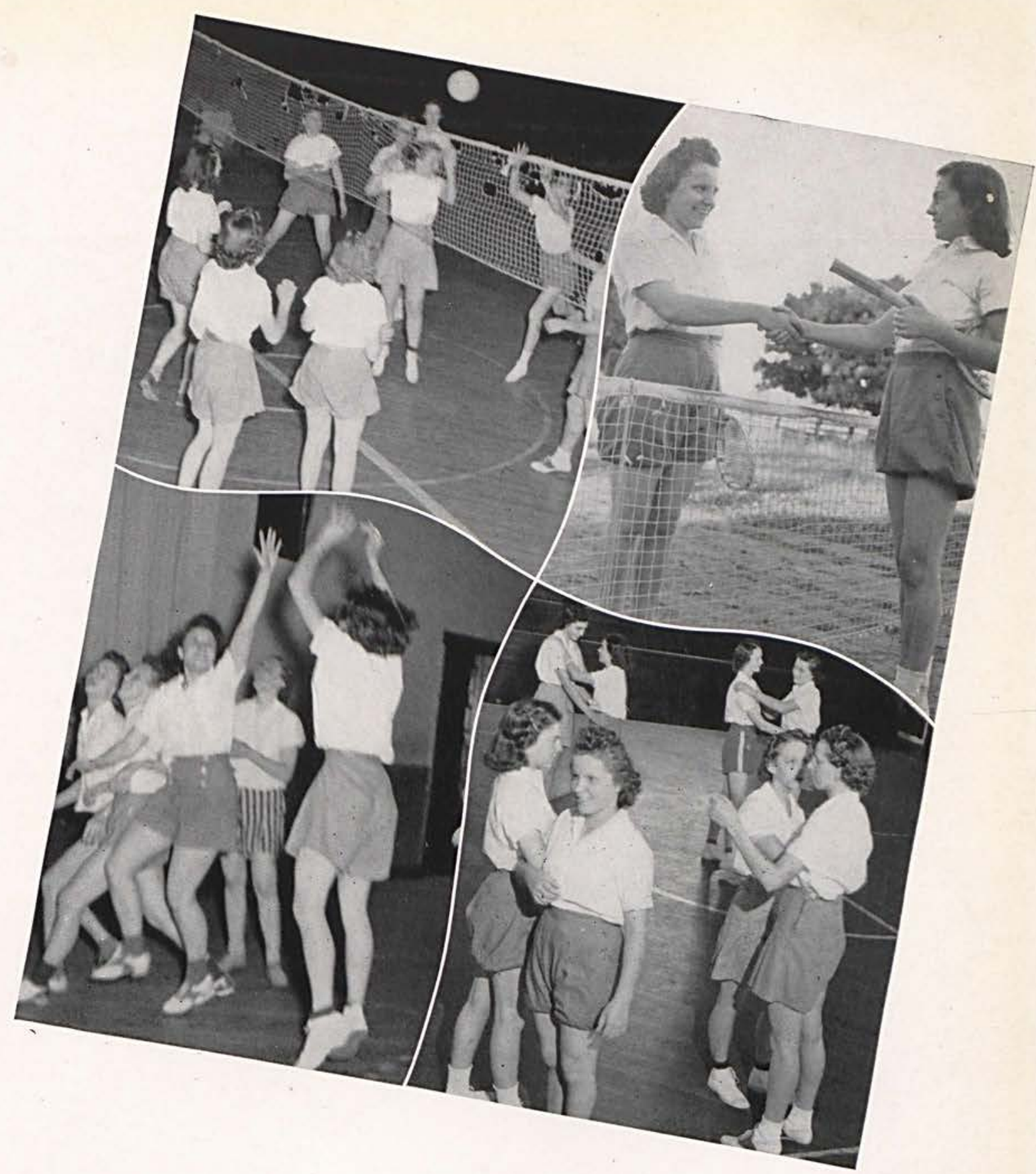

A match game in volleyball is in progress. Just a friendly game between Margaretta Garrison tries to stop Williams' shot, but it is good. and Orsadee.

Some of the girls here are going through some intricate dance formations. 
BOOK THREE

Their Activities

$C L U B S$ 


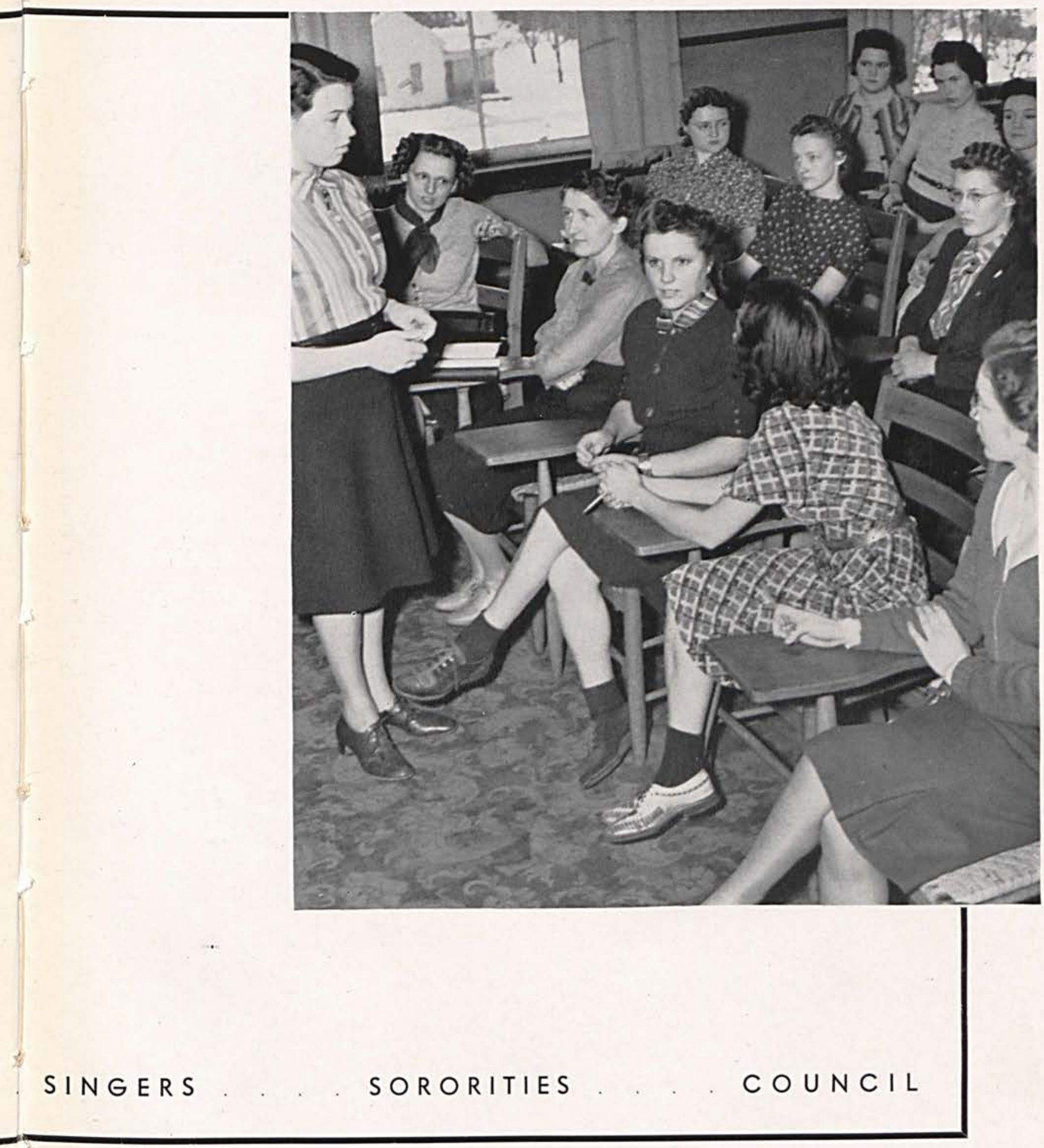




\section{STUDENT COUNCIL}

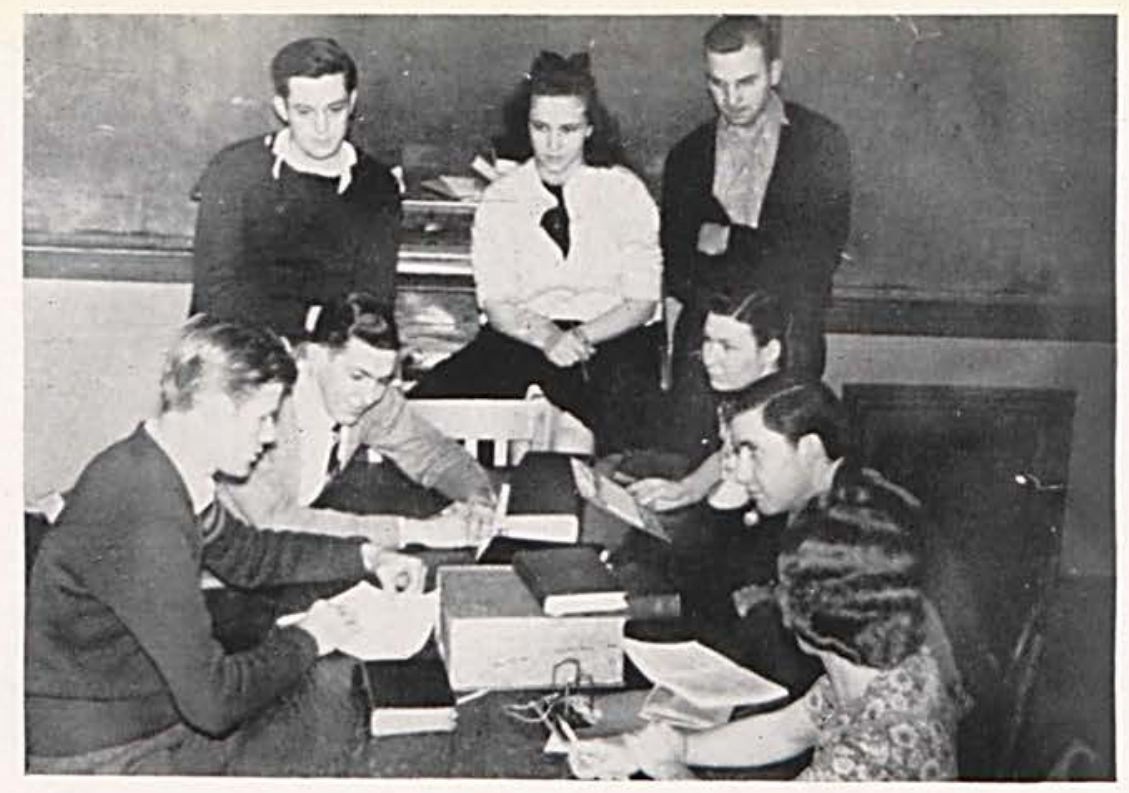

SEATED: Roberts, Hartman, Bickett, Foster, Gossard. STANDING-Brill, Garrison, Northup.

The Student Council is composed of representatives of the student body and faculty. It was organized to take care of any school problems which might arise.

At the head is the Student Body President who is chosen each spring to be able to lead in class organization, freshman week, and other activities when school opens the next fall. He is ably assisted by representatives from each of the classes, the president and the two deans of the college.

The membership is composed of Russell Roberts, Chairman and Student Body President, Neil Hartman, John Brill, and Henry Foster, the senior, junior, sophomore and freshman class presidents respectively. There is an additional representative from each of the classes.

The faculty is represented by Dr. W. R. McChesney, president of the college, Miss Helen Santmyer, dean of Women, and Mr. C. W. Steele, dean of Men.

Russel Roberts, President, Student Council. 
The dramatics club was organized this year with the following officers: Neil Hartman, president; Clayton Wiseman, vice-president; and Norman Linton, secretary-treasurer.

The Dramatics Club met at least once a month during the year. The following plays were presented at the regular meetings by members of the society: "Honor". "For the Love of Kitty", scenes from "Abraham Lincoln in Illinois", "Auf Weidersehen". "The Valiant", a skit satirizing futuristic painting, a radio play and "On Account of the Lobster."

The faculty presented a play, which was entitled, "The Pot Boiler", at one of the regular meetings. The members of the club gave two plays in the Methodist Church during the year. The first one was "The Topaz of Sthiopia", a Christmas play and the second one was "His Cross" an Easter play. The society also presented programs at South Solon and Jamestown. At these meetings the play "Roses and Haircuts" and a skit were given.

Miss Basore had charge of several of the meetings. She reviewed the plays in New York; gave a demonstrated lecture on stage rules; and she conducted a group of pantomimes. At one meeting Mr. Kilpatrick reviewed the plays and operas that he saw in Europe.

The climax of the year was the commencement play, "Nothing But the Truth" which was sponsored by the Dramatics Club.

Neil Hartman, President.

Hartman, Johnson, Corn, West, Reinhard, Galey.

McClellan, Anderson, Townsley, Guthrie, Linton, Fehlmann, Garrison.

Miss Basore, Gossard, Goodin, Owens, Finke, Williams.

Tanksley, O'Bryant, Gilliam, Stebbins, Lott, Stewart, Chitty, Nelson.

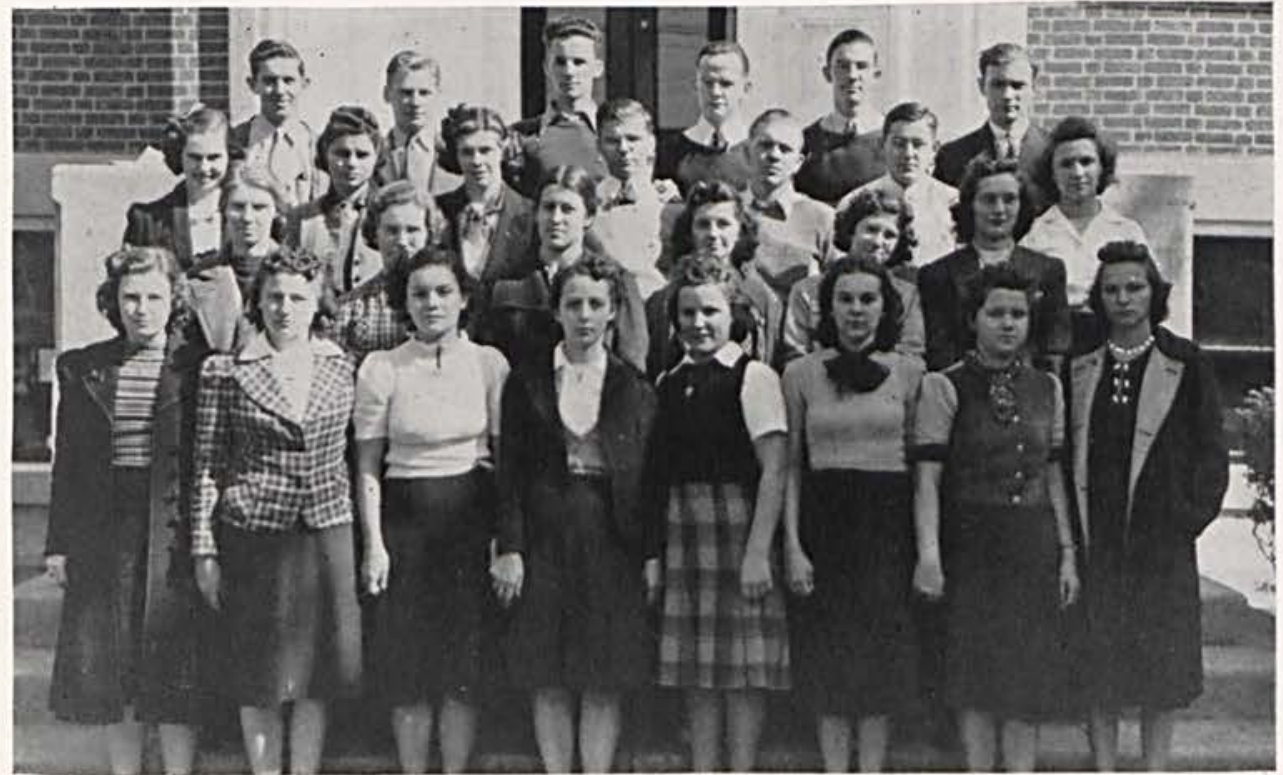


Work on the Cedrus began last fall and there has been something going on constantly in one way or another to make this a book that will bring pleasure to us in years to come.

The staff has responded well to get the work completed. The many organizations have helped exceptionally well. We are grateful to all these and most certainly to Bill Freund who is very largely responsible for the putting together of this 1940 edition.

We sincerely hope that you will enjoy looking through this book in the future. We feel it will be a most cherished book in your collections.

Russel Roberts, Cedrus Editor.

C. Ferguson, Owens, Stewart, P. Ferguson, McClellan.

Townsley, Brill, Rigio, Thomas, Anderson, Roberts, Linton, Garrison.

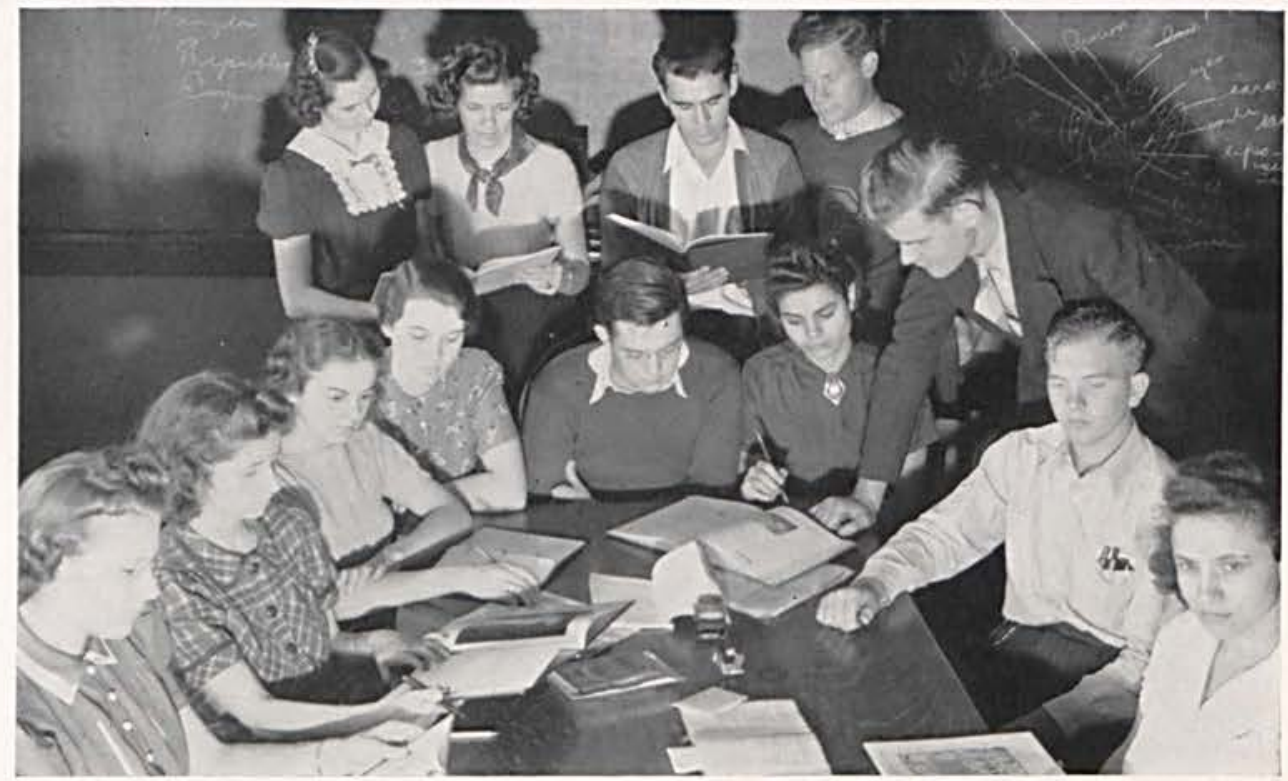


The editor-in-chief this year of the college weekly was Burns Tanksley. He has done a commendable job in getting the most from his staff. He was ably assisted by Orsadee Stewart, the assistant editor. Betty Lee Garrison became noted for the amount of scandal she found for each edition. The art editor was Janice Finke who did a fine bit of picture-making for the front page. The sports editor could be listed as second to none. Arthur Geake may be commended in keeping the students up in the world of sports. The typists, Catherine Ferguson, Ted James, and Hazel Bush could always be counted upon to do their part.

There were several good editorials which showed some forethought on the part of the editor. The scandal page often created quite a furore among the students but it was all taken in good fun.

The students and faculty have always been entitled to express their various opinions on any subject which in any way brings closer together all those here at the college.

I believe we can truthfully say this year's paper has been a great success.

\section{WHISPERING CEDARS STAFF}

\section{Burns Tanksley, Editor.}

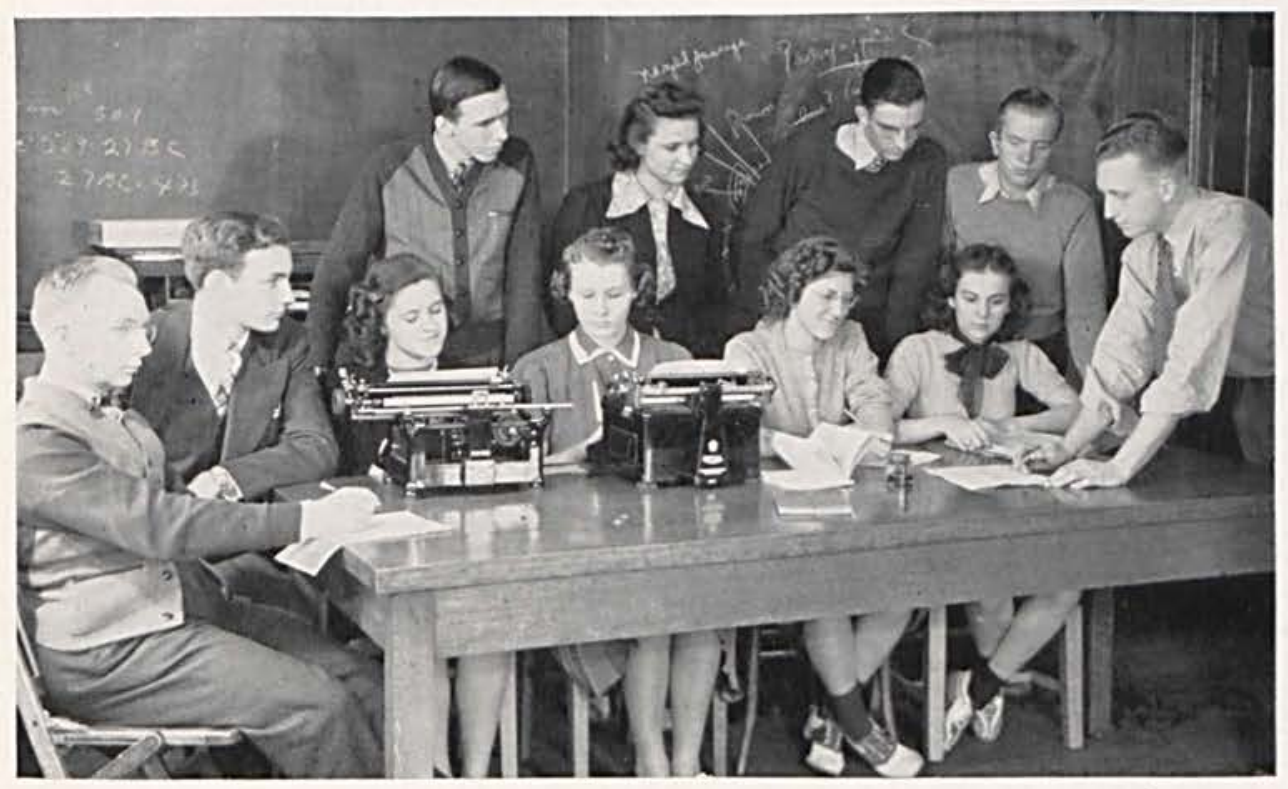


The Y.M.C.A. of Cedarville College is proud to have such a fine group of young men, who are interested in living a clean and healthy life. This organization has encouraged good fellowship among the members and those whom they come in contact with also. A spirit of leadership has been developed too.

We are very grateful to our program chairman, Neil Hartman, in bringing to us so many outstanding and interesting speakers. The Y.W.C.A. has given fine cooperation, and the joint meetings have given great benefit to both organizations.

The Y.M.C.A. is perhaps one of the oldest and still the most cherished organizations upon any campus. It is a most necessary part of our college curriculum in binding Christian living to the rest of the scholastic program. In closing we are interested in accepting Christ as our leader over all.

FIRST ROW-Miller, Johnson, Geake, Fehlmann, Guthrie, Linton, Foulks. SECOND ROW: West, Galey, James, Northup, Shaw, Keener. THIRD ROW: Wilson, Thomas, Kavanagh, Lott, Bickett, Brown. FOURTH ROW-Rigio, Hartman, Roberts, Brill, Reinhard, Taylor.

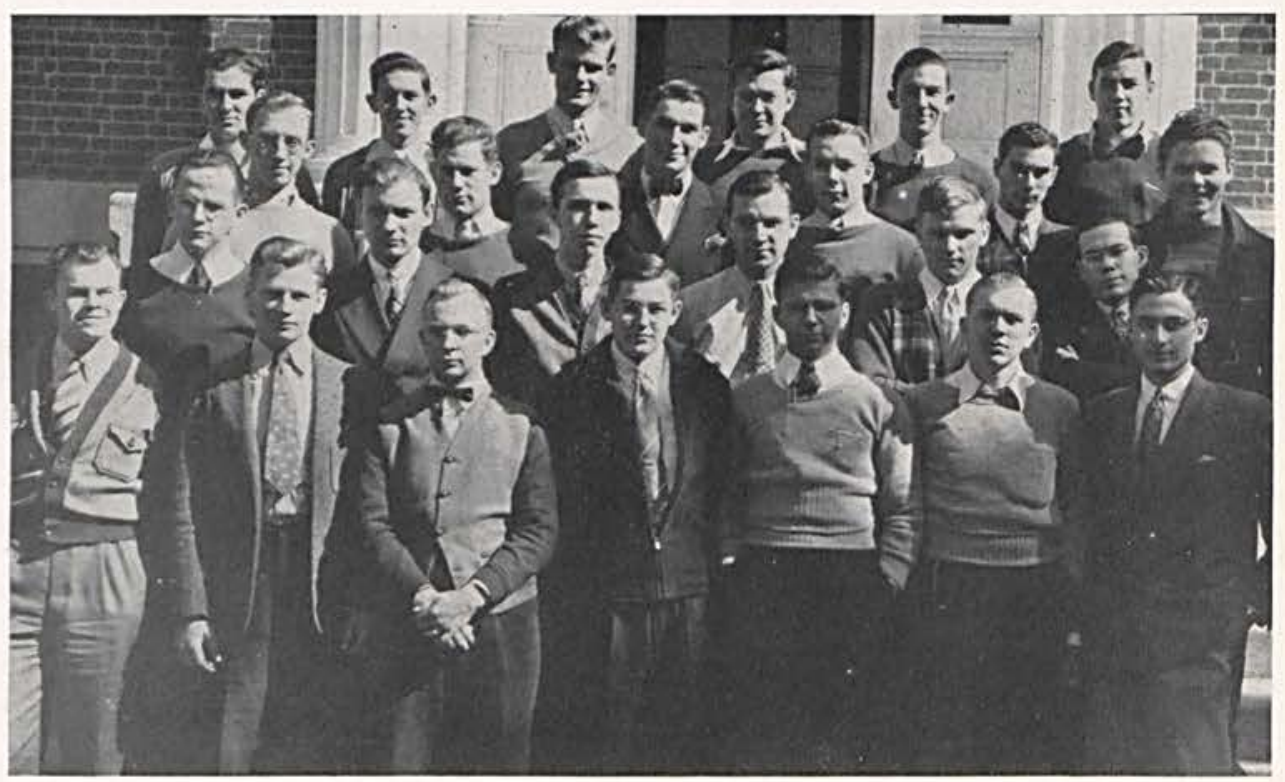


The Y.W.C.A. opened the school year with a "Big and Little Sister" Tea at the home of Doris Ramsey during the first week of school.

Following the usual custom, the girls drew names for "Secret Pals" and exchanged gifts during the six weeks before Christmas. During this time the girls were all wondering who their secret pals might be. This mystery was ended at the annual Christmas party at the home of Mrs. C. W. Steele.

In November the Annual Committal Service, in memory of Frances McChesney, was held at the Presbyterian Church. At this service the new members and the cabinet took their pledge of loyalty to the Y.W.

One Friday morning during March the girls tried to give the "Mock Wedding" during the Chapel period. Before it was all over the bride (Grace Bickett) was taken for a ride.

This year we sponsored a Spring Tea. It was held on April 12. in the gym. "April Showers" Tea would probably have been a better name for it since it rained most of the day.

As a climax of our activities of the year the girls and their mothers enjoyed a social time together at the Annual Mother and Daughter Banquet, which was held on Friday evening, May 10th.

The Y.W.C.A. has prospered well this year in having one hundred per cent membership. There have been very interesting meetings during the year, many of which were jointly with the Y.M.C.A. Pauline Ferguson, President.

FIRST ROW-P. Ferguson, Irvine, Creswell, Gilliam, Stebbins, Lott, H. O'Bryant, Spahr, Long.

SECOND ROW: Anderson, Jolley, Maddock, Ramsey, Chitty, Finke, Bush, Miss Basore, Stewart.

THIRD ROW: McClellan, Muller, Tanksley, O'Bryant, Randall, Ross, Batdorf. Bogenrife, C. Ferguson.

FOURTH ROW: Townsley, Edgington, Goodin, Nelson, Gossard, Owens, Ritenour, Williams.

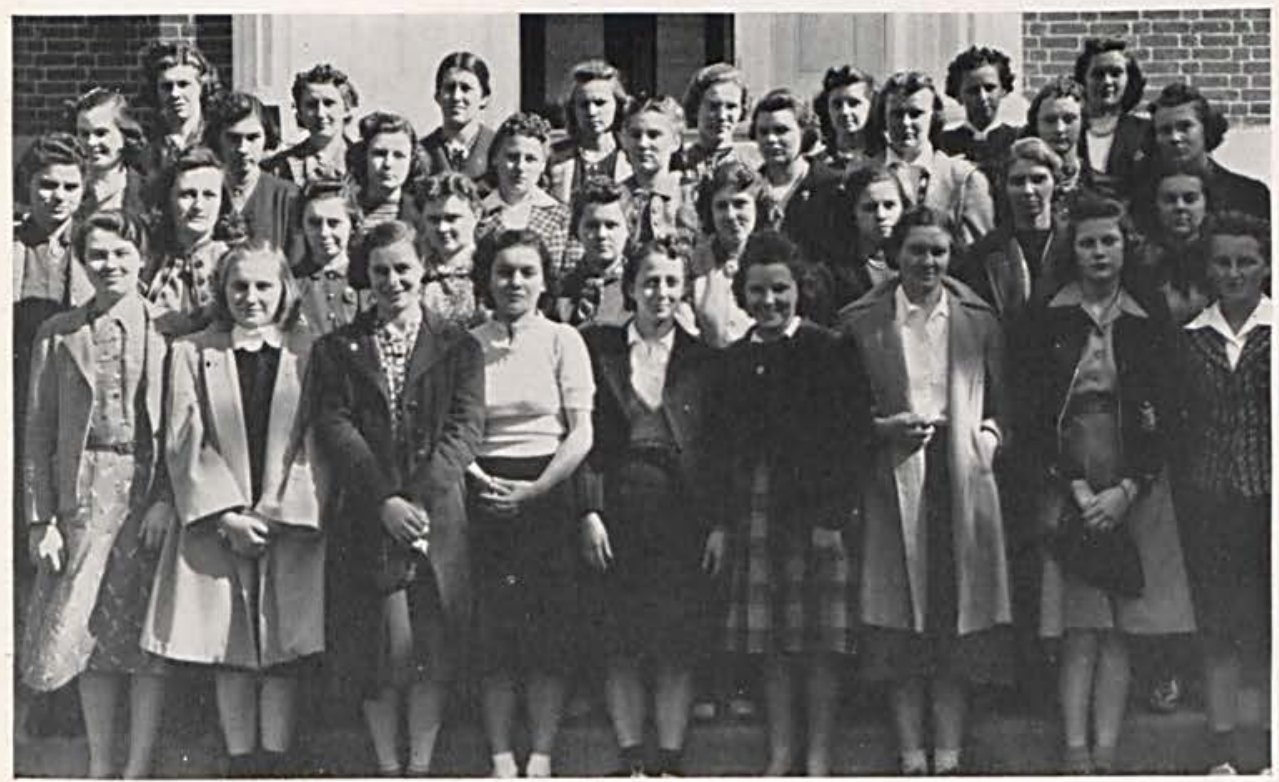




\section{A L P H A THETA TAU}

Another successful year has passed into history for the Alpha Theta Tau. Besides our regular meetings, we have enjoyed several socials.

Early in the year we had a covered dish supper with Janette Neal; um-um! What food; what cooks! Here we made plans for the year's work.

The outstanding activity of November was the Harvest-Time Party. Active members, alumnae, rushees and friends all joined in the fun. The Gym was quite effectively decorated with fodder and pumpkins. A rail fence set apart the table games from the dances and folk games. The balloon dance took the "cake." What a time each girl had to keep her balloon away from those tramping feet! Old friendships were renewed and new ones made on this night.

The December meeting was held with Jane Mills who kindly invited the Sorority and rushees to her home for the Christmas dinner. Gifts were exchanged; then the group went carol singing.

In January we helped Janette Neal and Mae Stebbins celebrate their birthdays. Did you know they were twins?

Katherine Randall opened her home for the pledge service the next month; later we attended a B.B. game.

In April we worked on the Sorority album with Doris Ramsey. What interesting memoirs pictures are! More good times are being planned for May, including a Cedar Day luncheon.

During the year our ranks were swelled to fourteen and what a time the pledges had initiation week.

To our active sisters continuing at C.C. we hand the torch and cry, "Carry it on high!"

Grace Bickett, President.

BACK ROW: Bickett, Ross, Randall, Batdorf, Mrs. Kling.

FRONT ROW: Neal, Stebbins, Chitty.

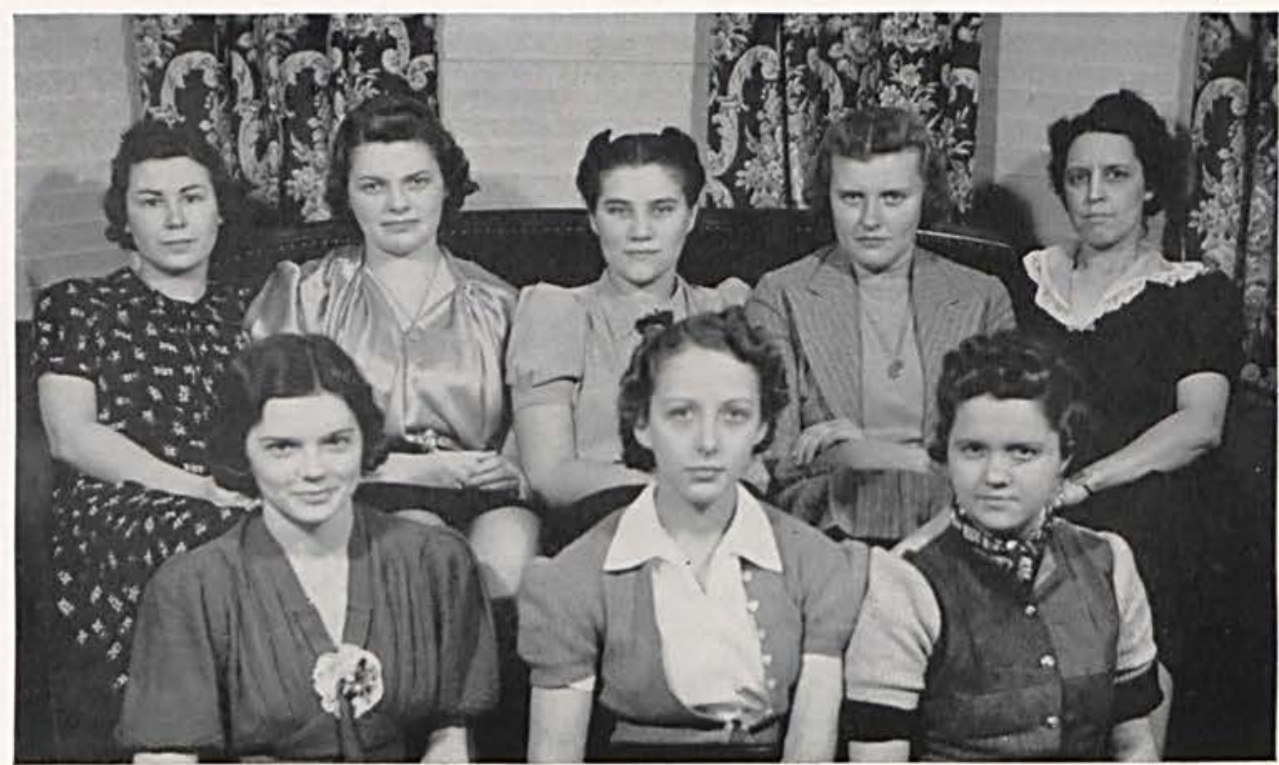


Our ranks were rather small at the beginning of the year and we added Margaretta Lott and Virgie Gossard to our membership. Miss Neistrath became our faculty advisor and our faithful Glenna Basore graduated to the position of honorary member.

This semester we have taken seven pladges into our ranks: Bette Lee Garrison, Catherine Ferguson, Beatrice Williams, Lillian Gilliam, Anna Lee Long, Martha Jayne Spahr, and Jane Jolley, and we think they will add their share to the Sorority.

In our customary manner we continued having fun. Our Christmas Alumnae luncheon was one of the highlights of the year. The "rush" slumber party was a never-to-be-forgotten occasion also. The "Leap Dance" hit a new high in Cedarville College history along with the lovely "May Formal." A supper party in honor of our pledges formal initiation was the feature that made us what we are today-seventeen sisters of Chi Sigma Phi who answer that familiar call, "Members of the Chi Sigma Phi Sorority will meet at Mrs. Harriman's at four o'clock."

\section{CHI \\ $S$ I GMA \\ $\mathrm{PHI}$}

THIRD ROW: McClellan, Miss Basore, Gossard, Ferguson. SECOND ROW: Miss Neistrath, Townsley, Anderson, Finke. FIRST ROW: Edgington, Stewart, Ritenour.

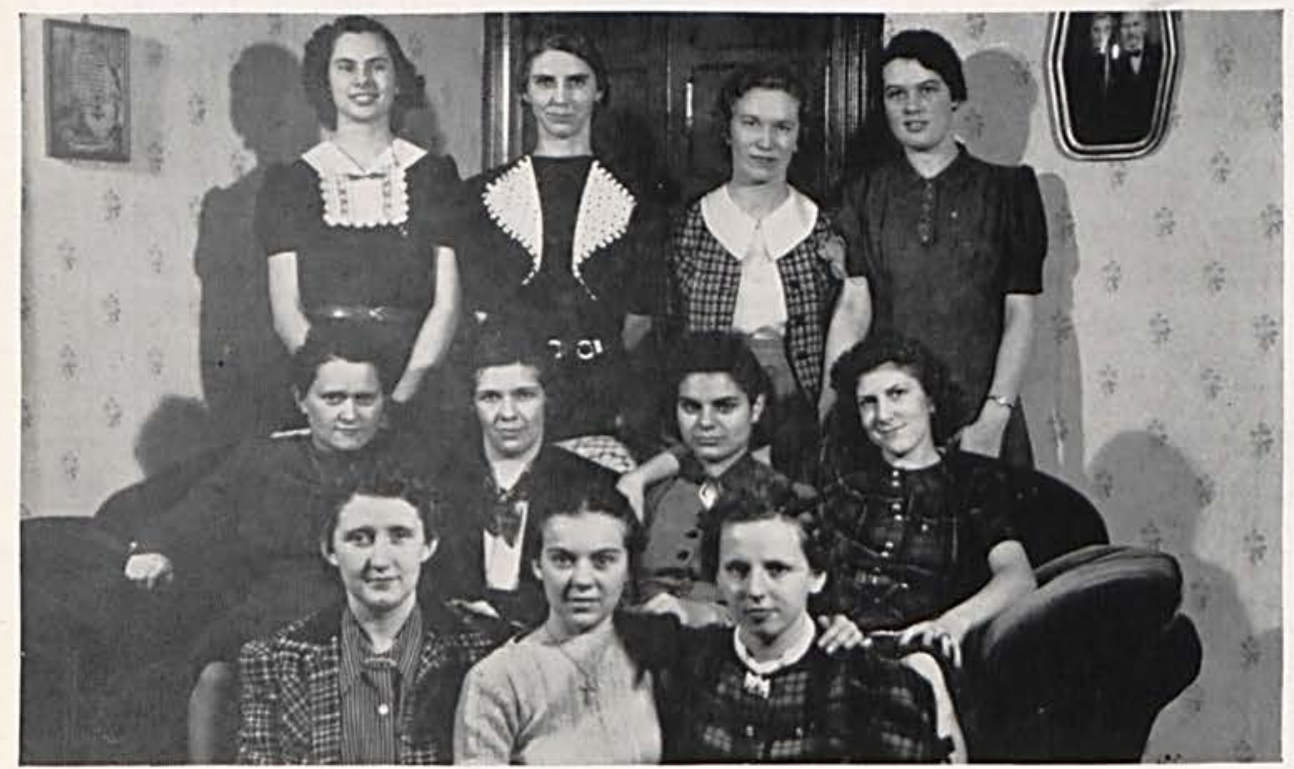




\section{GOSPEL TEAM}

This last semester has been a very active one for the Gospel Team. We have received several new members: Bette Lee Garrison, Beatrice O'Bryant, Eugene Stewart, Helen O'Bryant, and Dorothy Bogenrife. The following officers were chosen: Irene Goodin, business manager; Doris Ramsey, secretary and treasurer; Virgie Gossard, president. The other active members are Isabel McClellan, Junia Creswell, Donald Foulks, Ted James, Royden Johnson, Vona Ruth West, and Montgomery West.

Committees were appointed to take charge of our weekly meetings. Among the meetings of outstanding interest, perhaps the one of greatest interest was the one in which each member chose a Bible character and told how this character had influenced his life. Some of our weekly meetings have been held in private homes. Two homes in which very interesting meetings have been held were those of Dr. Markel and Mr. Gordon.

We have been invited to conduct services in several churches. In Cedarville, services were held in the Methodist Church and the Zion Baptist Church. The other services were held at the following places: Catawba, Bookwalter, Pitchin, South Solon, Mount Sterling, and Jamestown. Some of the topics of the meetings were-"Hearing the Still Small Voice", "Christian Methods of Action", "Prayer", and "Christian Service".

All of the members of the Gospel Team wish to express their appreciation for the loyal support of all friends in Cedarville College and elsewhere. We have enjoyed the Christian fellowship in the service of Jesus Christ.

E. Stewart, Gossard, Owens, Foulks, Creswell, Johnson, Ramsey, Goodin.

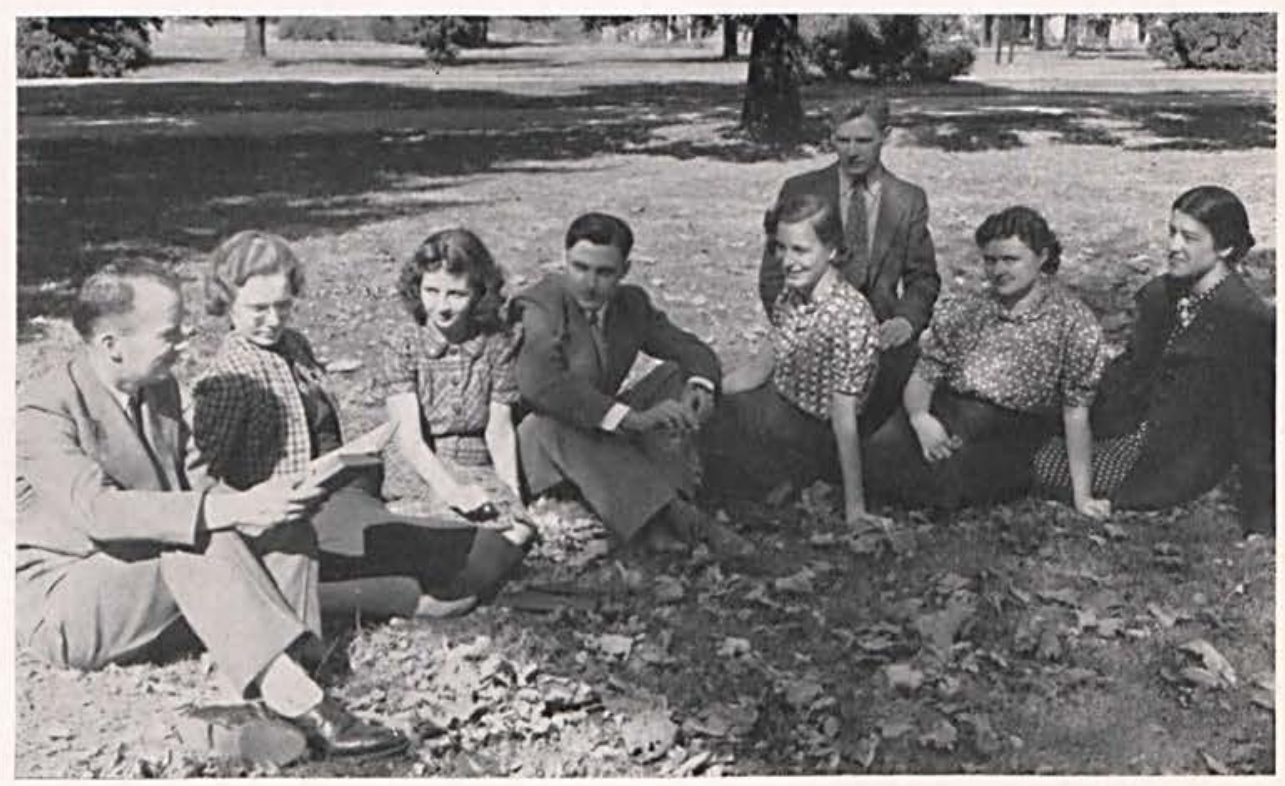




\section{MUSIC . . .}

The college choir was composed of twenty members this year who faithfully rehearsed every Monday and Wednesday evenings in the basement of the library.

The choir sang at all the religious services which were sponsored by the college. These services were the Men's Bible Reading contest in November, the Day of Prayer in February, and the Women's Bible Reading contest in March, and the Baccalaurete Service.

The choir participated in a musical program at Wilberforce on International Day, February 12, and a meeting of the Jamestown P.-T.A.

The three main programs which were sponsored by the choir this year were a Christmas cantata, an Eastern oratorio, both of which were held in the Presbyterian Church, and a "Ye Old Folks Concerte" which was held in the gymnasium.

Mrs. Mary C. Markle is the director and accompanist for the choir.

Chitty, Nelson, Stebbins, Johnson, Lott, Guthrie, Miller, Hartman, Owens, Long, B. O'Bryant.

Mrs. Markle, Neal, Finke, Goodin, McClellan, Creswell, Williams. Anderson, Ritenour, H. O'Bryant, Tanksley, Stewart, Gilliam.

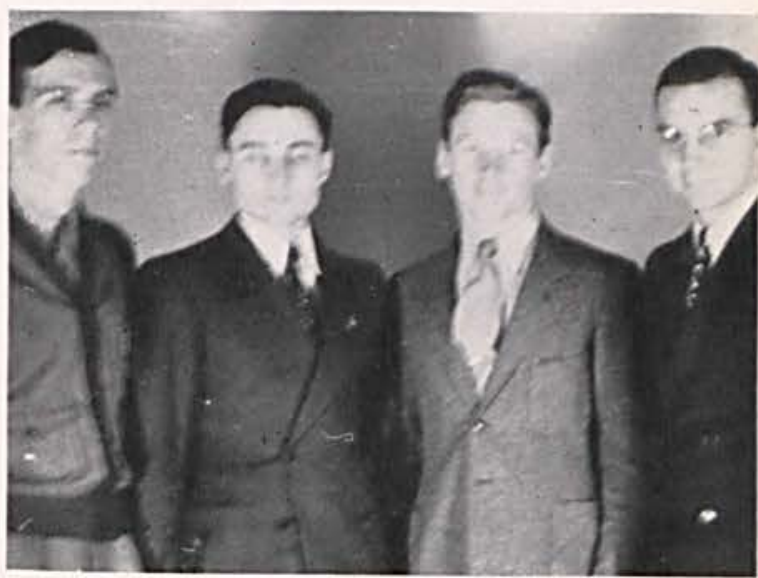

James, Foulks, Johnson, Northup.

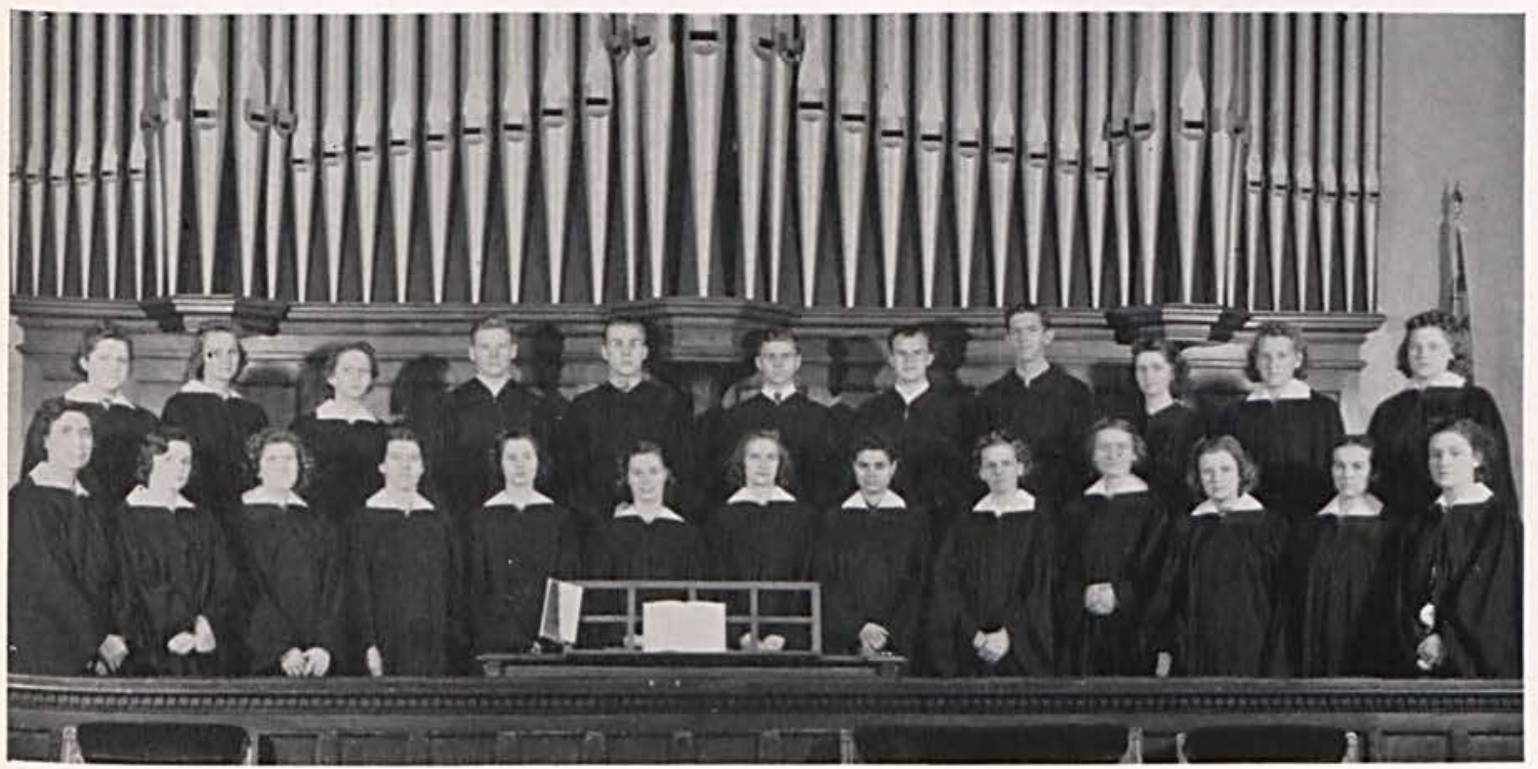




\section{$C E D A R$}

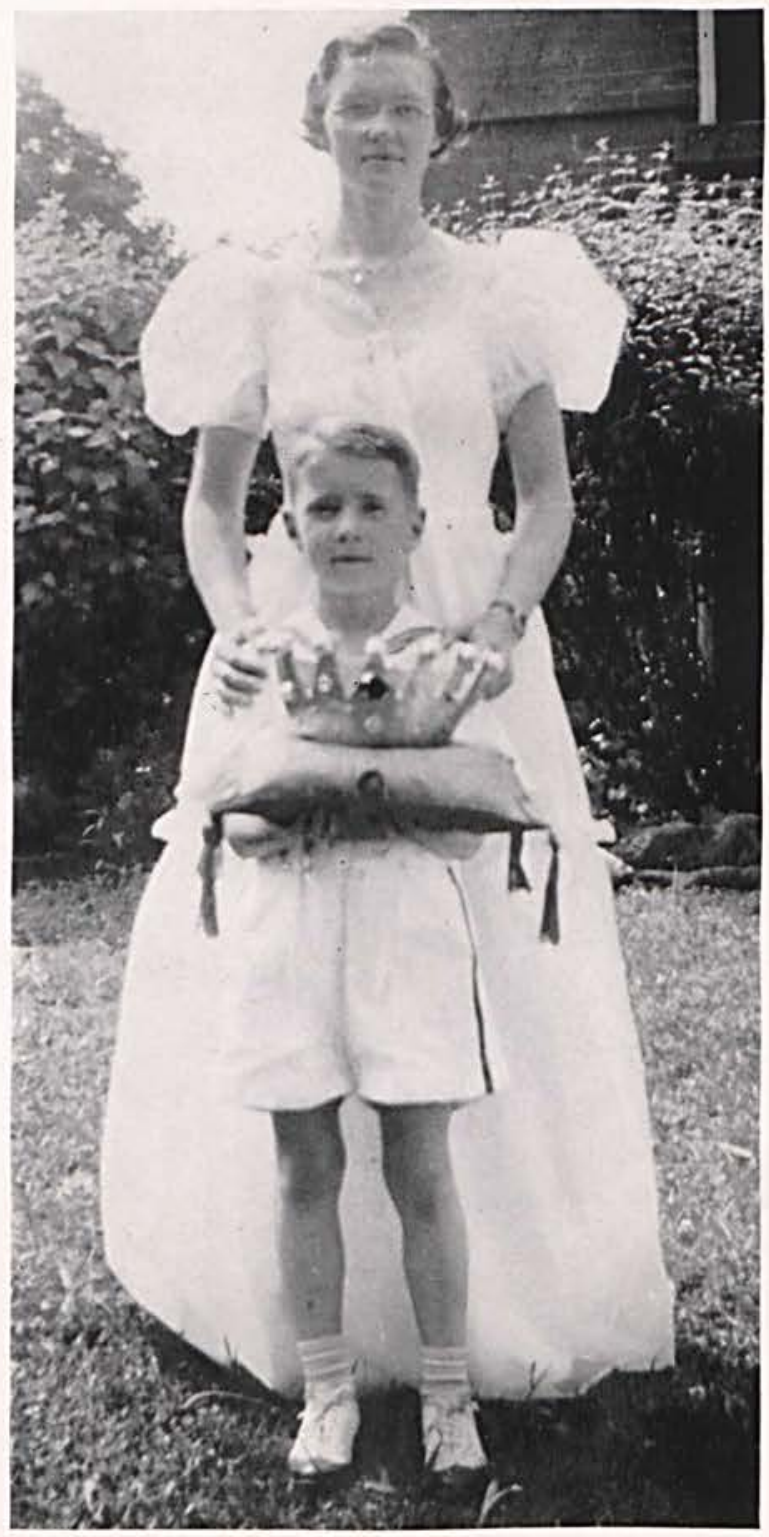

Cedar Day Queen............ Miss Jane E. Frame

Crownbearer. David Markle, Jr. 


\section{DAY .... 1939}

\section{PROGRAM \\ CEDAR DAY}

1939
I. PROCESSIONAL
II. CROWNING OF THE QUEEN
III. PAGEANT OF THE MONTHS
IV. TUMBLING ACT
V. CLASS STUNTS
VI. THE ORATION-JOHN FOX
VII. THE FINALE-COLLEGE SONG
VIII. RECESSIONAL
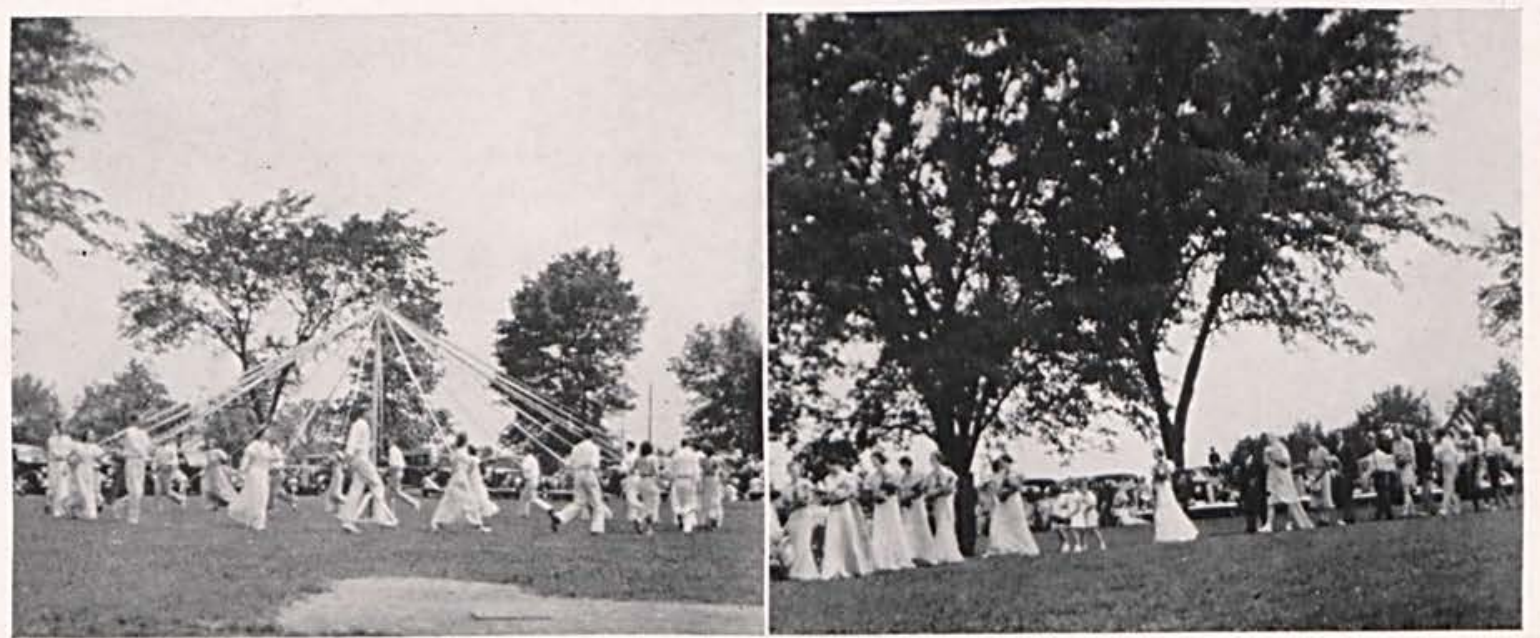
RECORDINGS OF TH

Kavanagh and Roberts leaving floor at half-time.

Clyde and Janette always having a good time.

Once again our good friend Art. Kavanagh didn't know about this. Lucky working hard on that Greek.

Anna Lee and Martha Jayne just dropped down for a "coke."

Miss Niestrath finds a football partner at Fall Sports Dance.

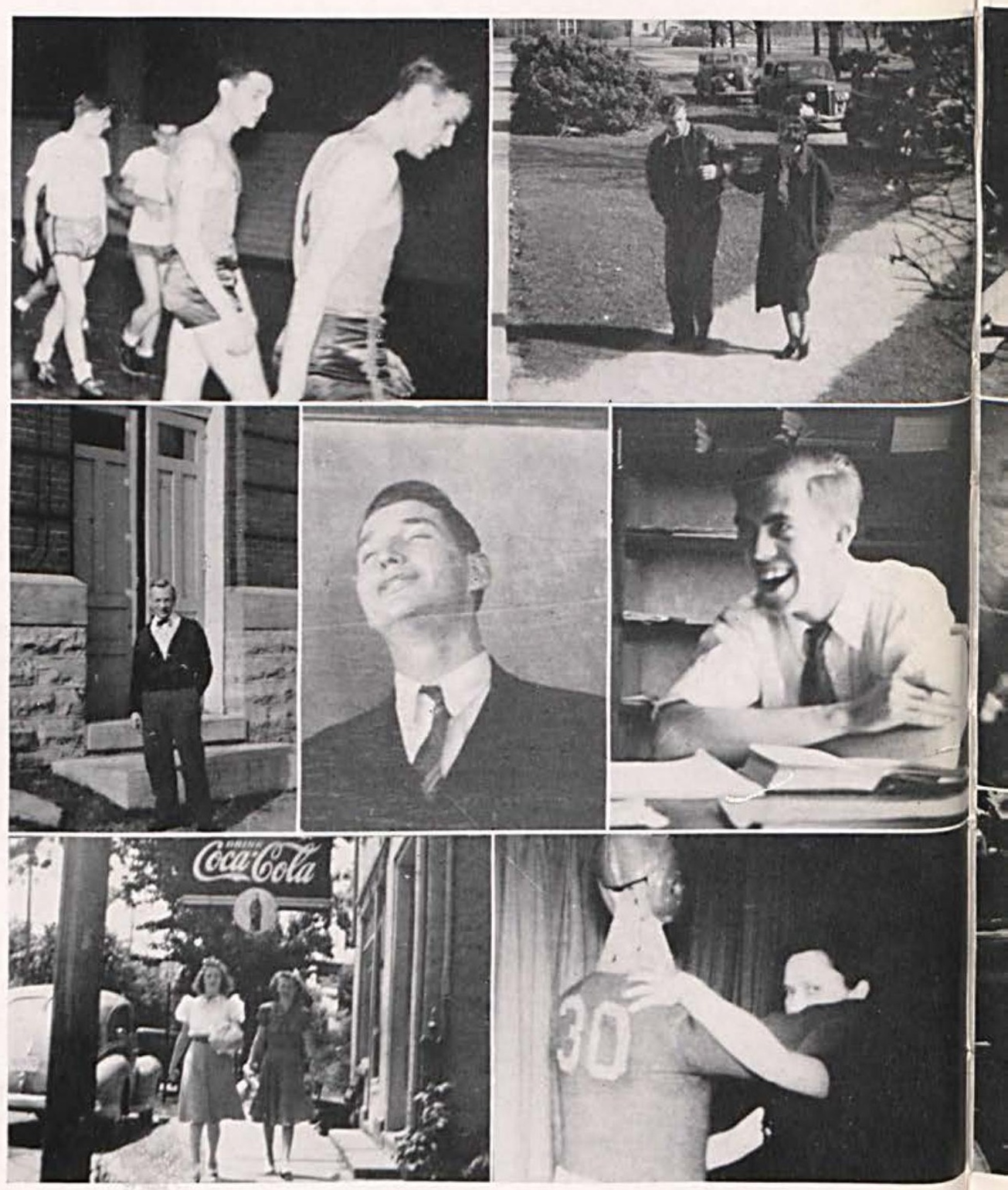




\section{SEPTEMBER}

Tues. $5 \ldots \ldots \ldots$ Whoops, my dear, we're here to stay,

Curses on Registration Day!

Wed. 6............"Hi ya', Joe", "Say how's tricks"

Classes start and school life clicks.

Sun. $10 \ldots \ldots \ldots$. Seriously now, for just a minute,

Convocation and all that's in it.

Tues. 12 .......... Dramatic Club-a meeting brief,

Review of Lincoln, by our "Chief."

Wed. 13............ A Freshman Laddie likes to play,

Came home from Mason late to-day.

Tues. 19..........." Watch the birdie!" don't you see,

The college picture, "That one's me!"

Wed. 20............ Painted boys, be-ringed girls,

The silly start of "Freshman whirls."

Thurs. $21 \ldots . . . . .$. Tug-of-war and scrawny pig tails,

Fishing in the street for Freshman whales.

Fri. $22 \ldots . . . .$. . Junior Class pitches big ball

At Bryan Park-six in all.

Wed. 27............A Foreign Authority spoke to-day $\mathrm{He}$ cleared his throat, but what did he say?

Thurs. $28 \ldots \ldots \ldots$..... A pajama parade staged by the Lassies, Buckets of water-and chilly chassis.

\section{OCTOBER}

Wed. $4 \ldots . . . \ldots$.... Freshmen prove they're smart indeed Beat the "Uppers" at a secret feed.

Thurs. $5 \ldots . . . . .$. Mum, can't remember that gorgeous smell?

Soph's sizzle sirlion-ain't it swell?

Fri. $\quad 6 \ldots \ldots \ldots$. Steele was upset. Do you recall

When a Stork upset his Chapel Hall?

Tues. 10........... Dramatic Club-"Honor" the play, And first rate honor goes to Clay.

Wed. I1............Jumping tom-cats, get the Coast Guard! Midnight Serenaders are in my yard.

Thurs. 12.......... People searching, looking all around

U. P. Scavenger upsets the town.

Fri. 13............ Friday the thirteenth! Now get set Varsity "C" Hayride was just "al Iwet."

Tues. $17 \ldots \ldots \ldots \ldots$. It's my proud privilege now to say. "A new Old Glory was raised today."

Mon. 23............What's that rumpus? Oh, my land, It's a real "Jam session" by the Wilberforce Band.

Mon. $30 \ldots \ldots \ldots$. Expect all men to appear in a sling.

Six man football is in full swing.

Tues. 31........... "For the Love of Kitty" was a clever skit. "Tunney" and Jolley make a record hit.

\section{NOVEMBER}

Sun. $5 \ldots . . . . .$. Men's Bible Reading, and the bestNorthup, Hartman, and Montgomery West.

Wed. 8............ Hunting season. Our friend Mr. Dorst

Gets a pig and a chicken, What? No horse?

Fri. $10 \ldots \ldots \ldots$...... Prettiest decoratin' I ever saw,

Harvest Dance by Alpha Theta Tau.

Sun. $12 \ldots \ldots \ldots$. Pretty as a picture, girls in white,

Y. W. Committal by candle-light. 
Tues. $21 \ldots \ldots \ldots$. A Fall Sports Dance staged to-night. The Varsity " $\mathrm{C}$ " is just all right!

Thurs. $23 \ldots \ldots$....... Thanksgiving funny, or did you hear?

F. D. R. mixed the dates this year.

Tues. $28 \ldots \ldots \ldots$. The Seniors pose all around

Had pictures taken to-day in town.

\section{DECEMBER}

Fri. 1........... Send off skyrockets! Do we rate?

Springfield's whipped, let's celebrate.

Sun. $\quad 3 \ldots . . . . .$. . The Topaz of Ethiopa" was I'd say,

A mighty well given Christmas play.

Tues. $5 \ldots \ldots \ldots$...... Such acting talent is hard to beat. Faculty members give us a treat.

Fri. $\quad 8$.......... "Jackets" make Urbana fall.

Freshmen sponsor dance for all.

Mon. I1............At Mrs. Steele's all the gals, Meet elusive "Secret Pals."

Tues. 18..........Alpha Theta Tau entertains at Mills, Glee Club finds candle on window-sills.

Thurs. 14............ Are we good? Well of course.

We beat the socks off Wilberforce.

Fri. $\quad 15 \ldots \ldots \ldots$. So long, folks, don't you see?

We're off to trim a Christmas tree.

\section{JANUARY}

Tues. $2 \ldots \ldots$...... After all this fussin', it's queer to find, We're glad to be back at this old grind.

Wed. 3...........A Junior "Coaster," full of thrills, With Thomas and Gilliam taking spills.

Fri. $\quad 5 \ldots \ldots \ldots$..... S Slumber party (out of bed) The boys are beaten by Morehead.

Sat. b............ Holbrook leaves us exonerating. (Mr. Joe College is hibernating).

Thurs. $11 \ldots \ldots$......Wilmington College takes us for a ride, Zero weather, yet "fireworks" inside.

Tues. 16

Wed $17 \ldots \ldots \ldots \ldots$ (Exams, ain't no poetry in that!)

Thurs. 18

Mon. 22..........We're at it again, velly much fun, Presbyterian Party for everyone.

Fri. $\quad 26 \ldots \ldots \ldots$..... A car full of kids almost freeze,

While Miami brings us to our knees.

\section{FEBRUARY}

Sat. $\quad 3 \ldots \ldots \ldots$. Home-coming Guests by the score, See Holbrook defeated on our floor.

Fri. 9..........W Wishart of Wooster comes to speak,

A Day of Prayer end the week.

Mon. 12 ........... Internation Conference from coast to coast, Wilberforce College is a gracious host.

Tues. 13...........Whoever said B.B. was tame?

Overtime played at Wilberforce game.

Thurs. 15........... The story of "The Valiant" saint.

So again repeated with no complaint.

Fri. $16 \ldots \ldots \ldots$...... pep-rally, headed by the son,

Who recalls the deeds of Ironton. 
Sat. $17 \ldots \ldots \ldots \ldots$. Oh, but It's true. "Revenge is sweet."

We glory in Bluffton's defeat.

Sun. $18 \ldots \ldots \ldots \ldots$ Inducement to Sabbath School is that The new class is lead by President "Pat."

Mon. 19............ At the Leap Year Party all get their "filly" Of ridiculous fun and lots of chili.

Tues. 20.......... After a party, all the Chi Sigma's came, To a thrilling, if lost, Wilmington game.

Wed. $21 \ldots \ldots . . .$. Girls go to Wilmington, and they do, Prove that they play Basketball too.

Thurs. 29............. Leap Year Dance is full of thrills, With Co-Eds footing all the bills.

\section{MARCH}

Sun. $\quad 3 \ldots . . . .$. Women's Bible Reading, inspiring to see Hone goes to the Freshman, Bea.

Fri. $\quad 8 \ldots \ldots \ldots \ldots$ Great merciful heavens, of all the sly sledding. Girls use the chapel to pull the Mock Wedding.

Mon. I1............ Intra-Mural Festival proves fun The Junior Class whips everyone.

Wed. 13........... Blame it on the night or on fate, But most folks like the Freshman Skate.

Thurs. 14 ............. First a Sugar Camp party, then after debating, To Xenia, the Chi Sigma Phi goes skating.

Sat. $16 \ldots \ldots \ldots \ldots$. It was wonderful in more than one way, The honor we won at U. C. Play Day.

Sun. 24............. People of Cedarville all admire The Easter Cantata by the Choir.

Wed. 27 ........... The world's all right 'en everything! Here's the vacation that comes with Spring.

\section{APRIL}

Tues. 2...........Wearily we come back to school, And, Boss, dis ain't no April Fool!

Mon. $8 \ldots \ldots \ldots$...... An April Shower, one of the best, In honor of Mrs. Montgomery West.

Tues. $16 \ldots \ldots \ldots$. Chi Sigma Phi pledges in desperation Seek all sorts of stuff for initiation.

Thurs. 18........... Sophomore class almost decide Their "highlight" was Lott's hayride.

Fri. 19...........Music and Food is charmingly, Provided at the Y.W. Tea.

Tues. 23............ "Lanky" will orate and attractive Pauline Will shine this year as Cedar Day Queen.

Thurs. 25 ........... The Chi Sigma Phi entertains at Sears, The nicest supper for Pledges in years.

Tues. $30 \ldots \ldots \ldots$. Fun by the bushels and lots of hey, hey! At a party pitched by Margaretta and Mae.

\section{MAY}

Wed. I.......... The Glee Club gets a chance to sparkle, At a special treat by Mrs. Markle.

Fri. $\quad 3 \ldots \ldots \ldots \ldots$. Formals" are frightening, but the exception, Is the year's event, Dr. "Mac's" Reception.

Tues. $7 \ldots \ldots \ldots \ldots Y_{e}$ olde tyme music, and nothing less, Insures the Festival's success. 


\section{PAUL EDWARDS \\ Dodge and Plymouth Sales}

SHELL PRODUCTS

Phone 147

S. Main St.

CEDARVILLE, OHIO

MRS. C. G. CONNER \& SONS

\section{OLD MILL CAMP}

Special Dinners

SANDWICHES

CABINS

U. S. R. 42

Cedarville, Ohio

29 E. Main St.

Xenia, Ohio

\section{THE XENIA NATIONAL BANK}

1835

OVER A CENTURY OF SERVICE

1940

Capital Account $\$ 400,000$

Resources Over $\$ 2,300,000.00$

Phone II4 Detroit Street at Main

XENIA, OHIO 


\begin{tabular}{|c|c|}
\hline $\begin{array}{l}\text { GEYER'S } \\
\text { "A GOOD PLACE TO EAT" } \\
\text { I5 W. Main St. Xenia, O }\end{array}$ & $\begin{array}{l}\text { Cedarville Federal } \\
\text { Savings \& Loan Association } \\
\text { Accounts Insured UP To } \$ 5,000 \\
\text { MONEY TO LOAN ON REAL ESTATE }\end{array}$ \\
\hline $\begin{array}{c}\text { THE CRITERION } \\
\text { VALUE FIRST CLOTHIERS } \\
\text { Xenia, Ohio } \\
\text { Compliments of } \\
\text { HARNER ELECTRIC SHOP }\end{array}$ & $\begin{array}{c}\text { GALLOWAY \& CHERRY } \\
\text { Furniture - Draperies } \\
\text { Floor Coverings } \\
\text { Phone } 4 \quad \text { XENIA, OHIO }\end{array}$ \\
\hline $\begin{array}{l}\text { FAMOUS CHEAP STORE } \\
\text { WE SELL EVERYTHING } \\
43 \text { E. Main St. Xenia, Ohio }\end{array}$ & $\begin{array}{l}\text { FOR THE BEST MEALS } \\
\text { EAT AT NEAL'S } \\
\text { Students Always Welcome } \\
\text { CEDARVILLE, OHIO }\end{array}$ \\
\hline $\begin{array}{l}\text { BROWN'S DRUGS } \\
\text { THE REXALL STORE } \\
\text { Cedarville, Ohio }\end{array}$ & $\begin{array}{l}\text { HILLTOP GREENHOUSES } \\
\text { H. C. FENCKER } \\
\text { Phone 31 Jamestown, Ohio } \\
\text { Flowers for All Occasions }\end{array}$ \\
\hline $\begin{array}{c}\text { PICKERING ELECTRIC } \\
\text { CONTRACTOR \& DEALER } \\
\text { Philco Radios } \\
\text { Westinghouse Appliances } \\
\text { Phone } 22 \quad \text { Cedarville, } 0 .\end{array}$ & $\begin{array}{l}\text { FETZ BROS. } \\
\text { SANITARY GROCERY } \\
\text { Bell Phones } 42 \text { and } 43 \\
\text { Xenia, Ohio }\end{array}$ \\
\hline $\begin{array}{l}\text { C. E. MASTERS } \\
\text { GROCERY AND MEAT MARKET } \\
\text { Phone } 44 \quad \text { Cedarville, Ohio }\end{array}$ & $\begin{array}{c}\text { HILL TOP GROCERY } \\
\text { GROCERIES FRESH MEATS } \\
\text { ICE CREAM } \\
\text { I. E. Woodley }\end{array}$ \\
\hline
\end{tabular}




\begin{tabular}{|c|c|}
\hline $\begin{array}{l}\text { CROUSE'S GROCERY } \\
\text { STORE } \\
\text { FRUITS - VEGETABLES } \\
\text { HOME KILLED MEATS } \\
\text { Phone } 40 \quad \text { Cedarville، Ohio }\end{array}$ & $\begin{array}{c}\text { Compliments of } \\
\text { SHANE'S BARBER } \\
\text { SHOP } \\
\text { CEDARVILLE, OHIO } \\
\text { Compliments of } \\
\text { SOHIO PRODUCTS } \\
\text { JAMES BAILEY } \\
\text { Cedarville, Ohio }\end{array}$ \\
\hline \multicolumn{2}{|c|}{ THE CEDARVILLE HERALD } \\
\hline $\begin{array}{l}\text { P. J. McCORKELL } \\
\text { INSURANCE } \\
\text { Cedarville, Ohio }\end{array}$ & $\begin{array}{c}\text { WRIGHT'S } \\
\text { WHITE VILLA GROCERY } \\
\text { Cedarville, Ohio }\end{array}$ \\
\hline $\begin{array}{c}\text { Compliments of } \\
\text { FRANK CRESWELL } \\
\text { COAL - FEED - GRAIN - WOOL } \\
\text { LIVESTOCK } \\
\text { Phone } 100 \quad \text { Cedarville, Ohio }\end{array}$ & $\begin{array}{c}\text { C. L. McGUINN } \\
\text { COAL - SEED - GRAIN - WOOL } \\
\text { PURINA FEEDS } \\
\text { CUSTOM GRINDING AND MIXING } \\
\text { Phone } 3 \quad \text { Cedarville, Ohio }\end{array}$ \\
\hline $\begin{array}{c}\text { KENNETH LITTLE } \\
\text { GENERAL INSURANCE } \\
\text { Phone } 51 \quad \text { Cedarville, Ohio }\end{array}$ & 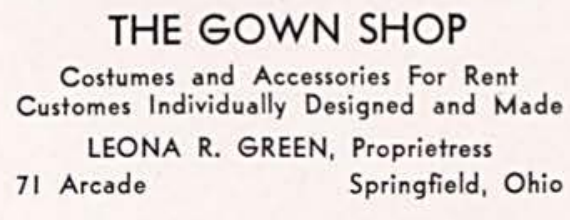 \\
\hline $\begin{array}{c}\text { R. J. BLACK } \\
\text { CANDIES AND TOBACCOS } \\
\text { URBANA, OHIO }\end{array}$ & $\begin{array}{c}\text { FRIED'S GIFT SHOP } \\
\text { REMOVAL SALE } \\
\text { Graduation Gifts }- \text { Reduced Prices } \\
\text { 6 E. Main } \quad \text { Springfield, Ohio }\end{array}$ \\
\hline
\end{tabular}




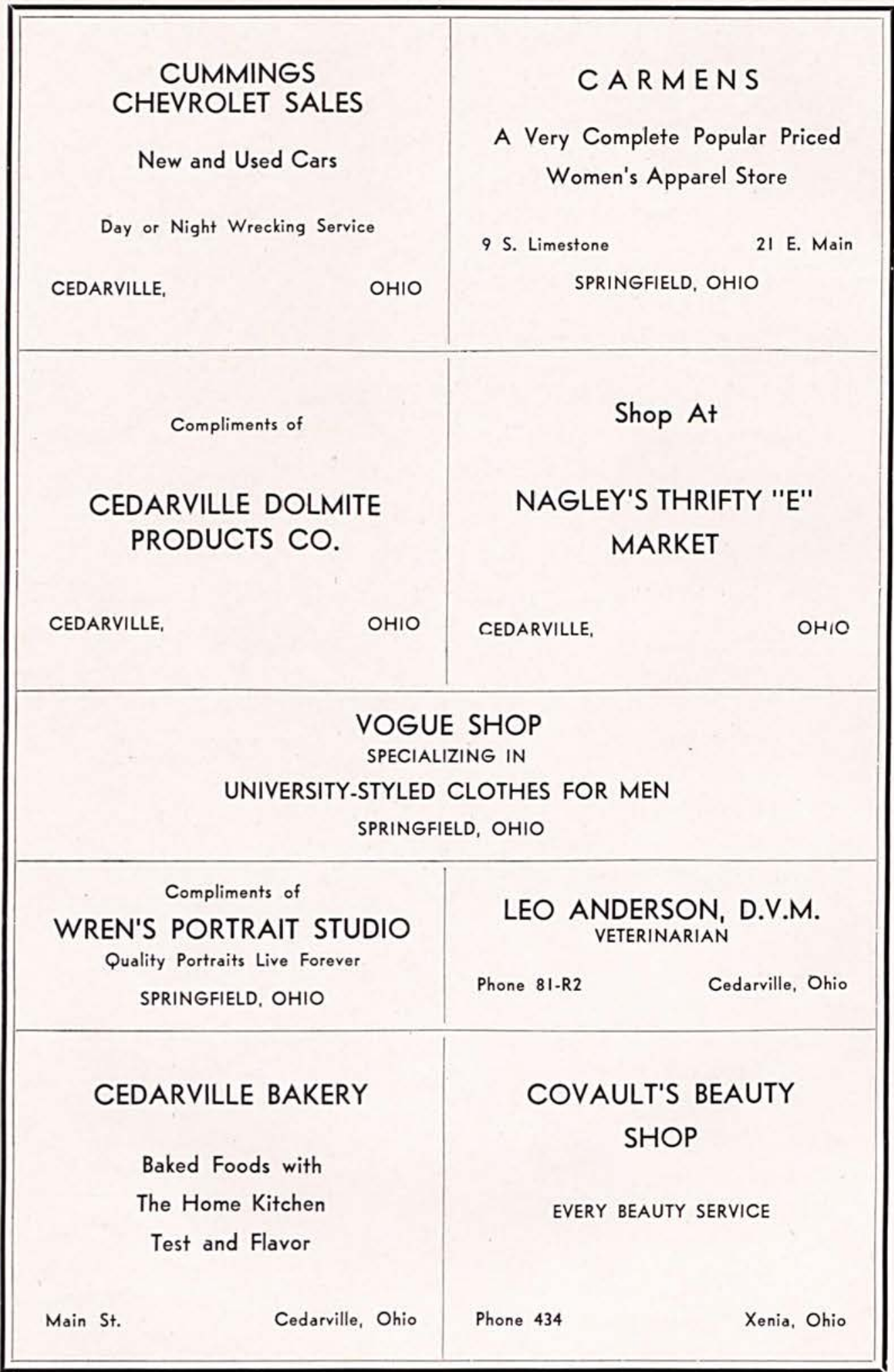


RECO SPORTING GOODS FOR BOYS AND GIRLS

\author{
THE RECO STORE \\ BASEBALL - SOFTBALL - TENNIS - GOLF \\ RACKETS RESTRUNG - FISHING TACKLE
}

16 W. High St.

Springfield, Ohio 
Autagraphs 


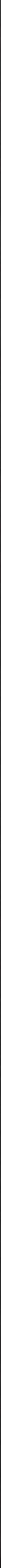





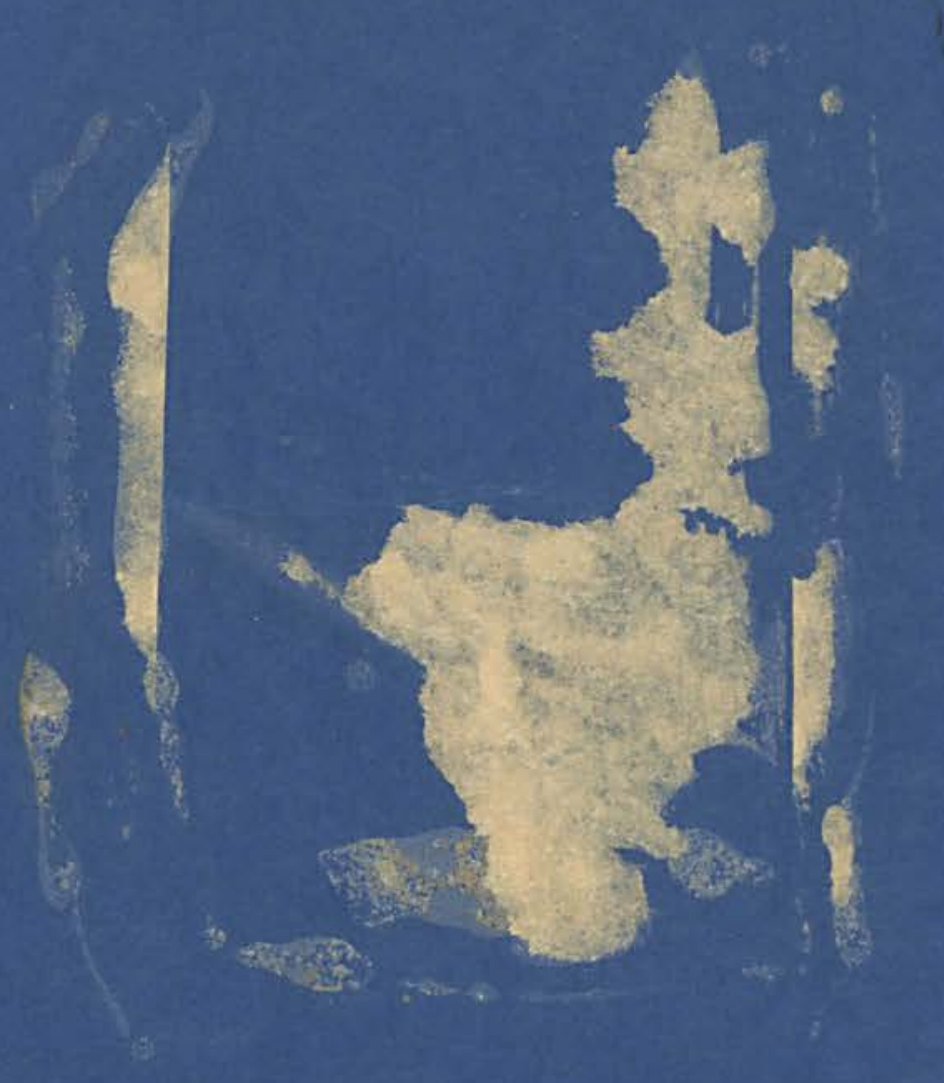




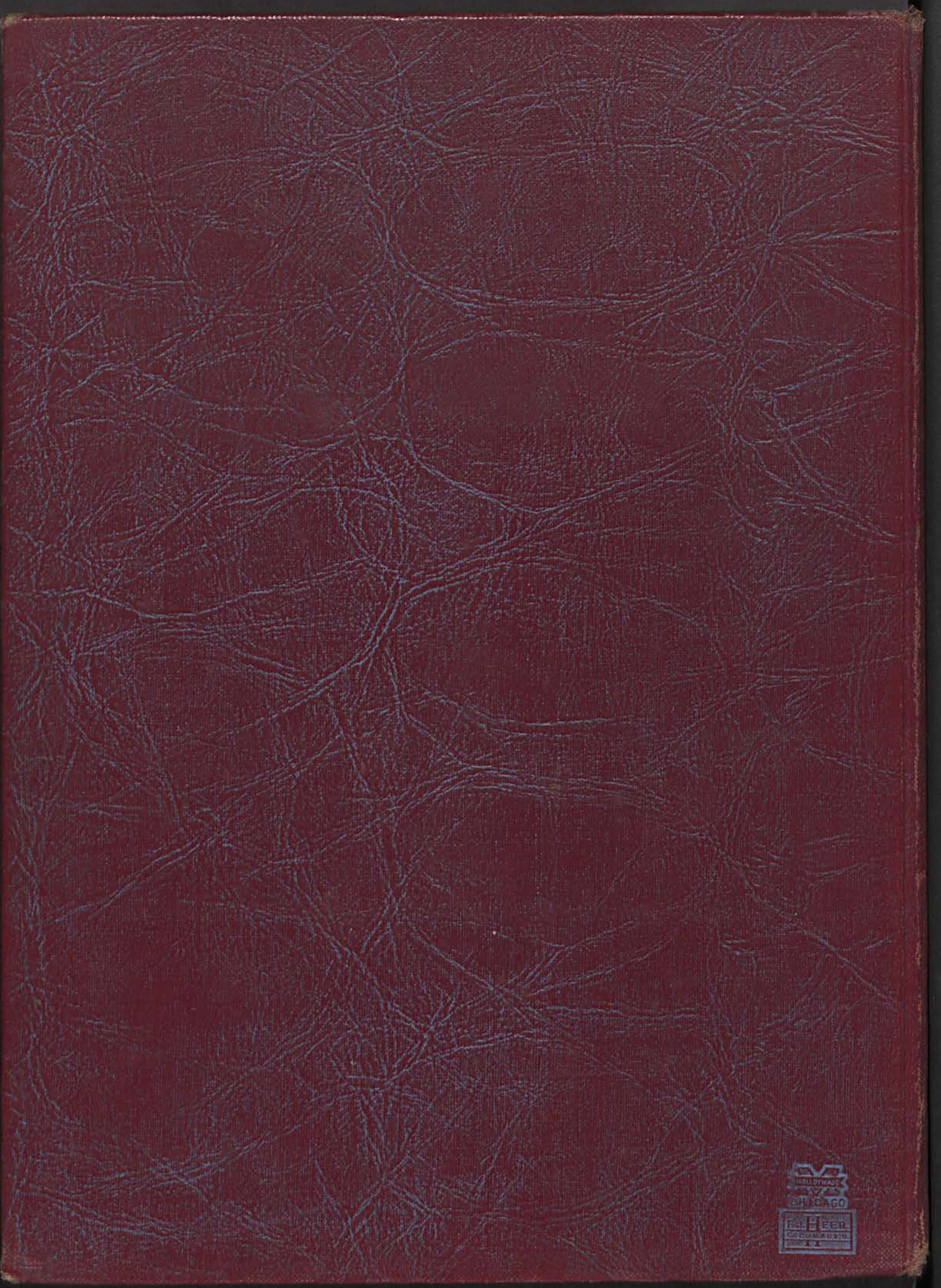

